\title{
COMPORTAMENTO ESPECTRAL E CARACTERÍSTICAS AGRONÔMICAS DA CULTURA DO FEIJÃO IRRIGADA COM DIFERENTES LÂMINAS DE ÁGUA
}

\section{CARLOS AUGUSTO HUNGRIA DA CUNHA}

Engenheiro Agrônomo

Orientador: Prof. Dr. RUBENS ANGULO FILHO

Dissertação apresentada à Escola Superior de Agricultura "Luiz de Queiroz", Universidade de São Paulo, para obtenção do título de.Mestre em Agronomia, Área de Concentração: Irrigação e Drenagem.

PIR A C I C A B A

Estado de São Paulo - Brasil

Outubro - 2000 
Dados Internacionais de Catalogação na Publicação (CIP)

DIVISÃO DE BIBLIOTECA E DOCUMENTAÇÃO - Campus "Luiz de Queiroz" /USP

..

Cunha, Carlos Augusto Hungria da

Comportamento espectral e características agronômicas da cultura do feijão irrigada com diferentes lâminas de água / Carlos Augusto Hungria da Cunha - - Piracicaba, 2000.

120 p. : il.

Dissertação (mestrado) -- Escola Superior de Agricultura Luiz de Queiroz, 2000. Bibliografia.

1. Caracteristica agronômica 2. Feijão irrigado 3. Reflectância espectral 4. Sensoriamento remoto I. Título

CDD 635.652 
A minha mãe Leda Assumpção Hungria pela árdua luta travada sob condições adversas, em pról da formação de cidadania dos filhos, ofereço.

Aos meus queridos avós

Acácio Soares Hungria e Edina Assumpção Hungria, com carinho e todo amor do mundo, dedico. 


\section{AGRADECIMENTOS}

A Esmeralda, por toda a sua simplicidade e paciência, me incentivando nos momentos mais difíceis e orientando de forma digna e correta os nossos filhos durante esse período.

A Cassia Fernanda e a Alessandra, minhas filhas, que compreenderam que este trabalho seria muito importante para nossas vidas e pacientemente abriram mão de um convívio maior com a minha pessoa.

Ao orientador e amigo Prof. Dr. Rubens Angulo Filho, que acreditou na possibilidade da realização deste trabalho e que compreendeu que juntos seríamos fortes o suficiente para desenvolver com méritos esta pesquisa.

Ao $\mathrm{CNPq}$, pela bolsa de estudos.

Ao Dr. Maurício Alves Moreira, pesquisador do INPE, pelas horas a mim dedicadas sobre como coletar e processar os dados radiométricos, bem como pela elaboração de toda a análise estatística. A sua força e simplicidade será sempre um exemplo a ser seguido pela minha pessoa.

Ao Dr. Bernardo Friedrich Theodor Rudorff, pelas sugestões apresentadas e pela análise dos dados radiométricos e agronômicos obtidos.

Ao diretor da ETAE Dr. José Coury - Rio das Pedras, Valdir Malacarne, que gentilmente cedeu as instalações e o material necessário para que este trabalho se tornasse possível, e compreendeu a importância de sua realização.

Ao amigo e engenheiro agrônomo, Anemézio Albertini, coordenador da ETAE Dr. José Coury - Rio das Pedras, pelo seu esforço, companheirismo, amizade e pelo tempo dedicado a esta pesquisa.

Ao técnico em agropecuária Antonio Erdiceu Verdi (Príncipe), pela realização do preparo do solo e plantio, bem como pelo interesse e acompanhamento do experimento em todas as suas fases.

Aos alunos do curso Técnico em Pecuária da ETAE Dr. José Coury - Rio das Pedras, Daniel Rolim Ciconello, Marcos Antônio Cerezer Zério, Rodrigo Largueza, 
Valter Antônio Pinto Filho e Evandro Ronney Sousa Filho, pela amizade, ajuda e incentivo, e principalmente pelo tempo dedicado à realização das práticas de campo, sem o qual este trabalho não seria possível.

Ao Prof. Dr. Marcos Vinícius Folegatti, por toda a ajuda e receptividade dispensada e pelo interesse demonstrado sobre o tema desenvolvido nesta pesquisa.

Ao Prof. Dr. Rubens Duarte Coelho, pelo seu apoio, atenção e orientação durante o decorrer do experimento.

Ao Prof. Dr. Carlos Alberto Vettorazzi, pelo incentivo e o convívio nestes bons tempos de universidade.

A Prof ${ }^{a}$ Fernanda Bacellar, pela sua atenção e ensinamentos preciosos da língua inglesa.

A Prof ${ }^{a}$ Dr. Sonia Maria de Stefano Piedade, do Departamento de Ciências Exatas da ESALQ/USP, pelo tempo a minha pessoa dedicado sobre como avaliar e utilizar corretamente os dados estatísticos.

Ao Departamento de Solos e Nutrição de Plantas da ESALQ/USP, na pessoa do Prof. Dr. Quirino Augusto de Camargo Carmello, pela realização da análise química do solo.

Aos professores e funcionários do Departamento de Engenharia Rural da ESALQ/USP, pela ajuda e amizade cultivada no decorrer do convívio acadêmico.

Ao técnico Gilmar Batista Gricolon, pela amizade e assessoria técnica na instalação e condução do delineamento experimental.

A pessoas especiais como Lilian Nogueira, pela sua ternura e paciência infinita, trazendo por fim a motivação necessária para que eu pudesse seguir em frente.

A todos que, direta ou indiretamente, contribuiram para a realização deste trabalho. 


\section{SUMÁRIO}

Página

LISTA DE FIGURAS ................................................................................

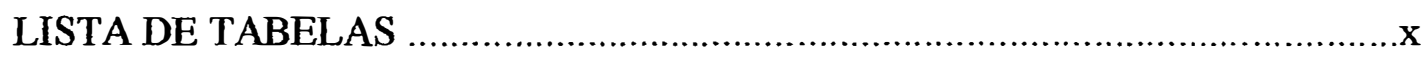

LISTA DE ABREVIATURAS E SÍMBOLOS .................................................ii

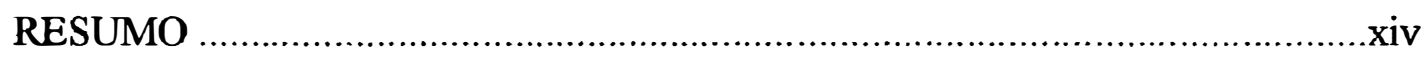

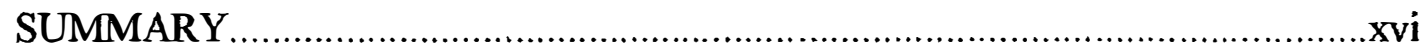

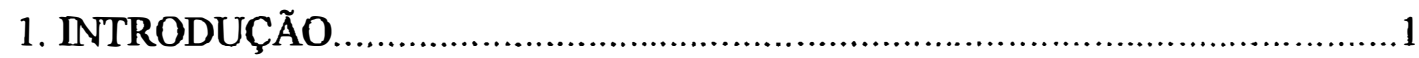

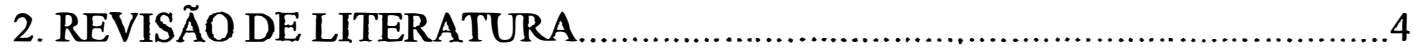

2.1. Importância da água na produção grícola .................................................

2.2. Efeito da irrigação na cultura do feijão..................................................... 7

2.3. Efeito de estresse hídrico na cultura do feijão........................................... 10

2.4. Sensoriamento remoto.................................................................. 13

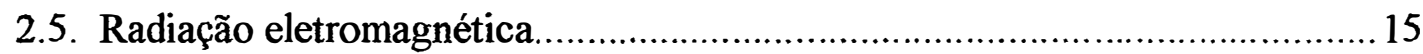

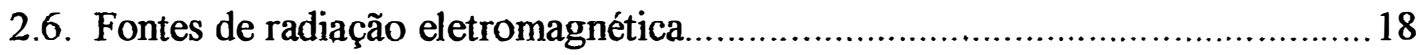

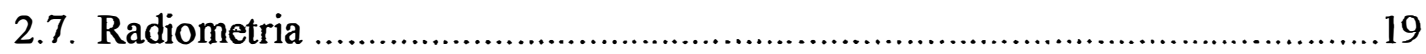

2.8. Comportamento espectral do dossel vegetativo...................................... 21

2.8.1. Região do visível......................................................................... 24

2.8.2. Região do infravermelho próximo................................................ 25

2.8.3. Região do infravermelho médio.................................................... 26

2.8.4. Fatores que afetam as propriedades ópticas da folha........................ 27

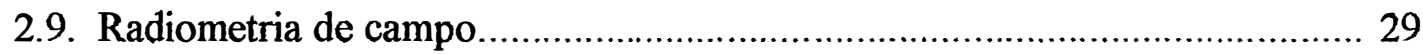

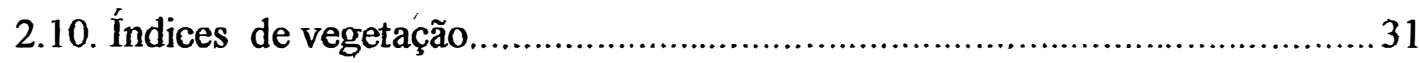

2.11. Radiação fotossinteticamente ativa absorvida pelo dossel vegetativo............34

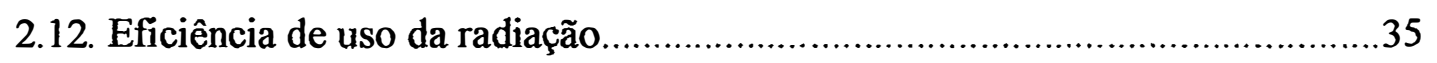

2.13. Comportamento espectral da cultura do feijão irrigada................................36

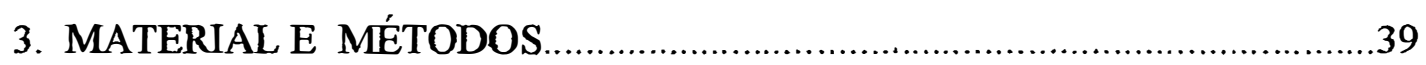

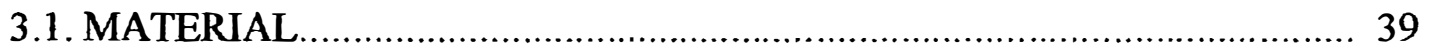




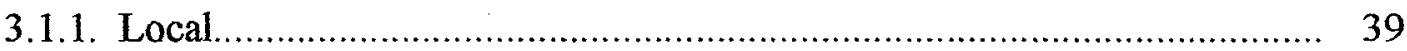

3.1.2. Clima

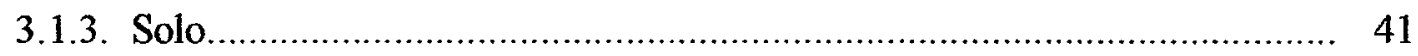

3.1.4. Variedade de feijão utilizada........................................................... 43

3.1.5. Sistema de distribuição de água ............................................................ 45

3.1.6. Medidas radiométricas sobre o dossel da cultura do feijão..................... 47

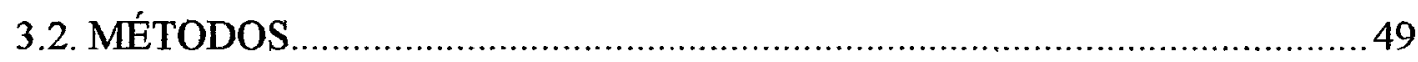

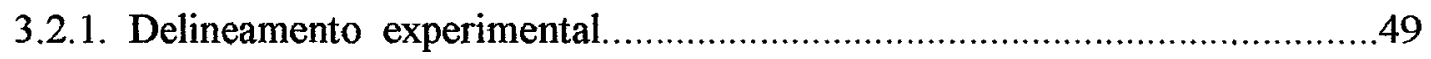

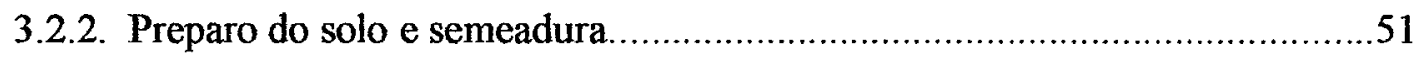

3.2.3. Tratos culturais e controle de pragas e moléstias........................................51

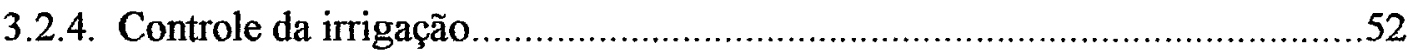

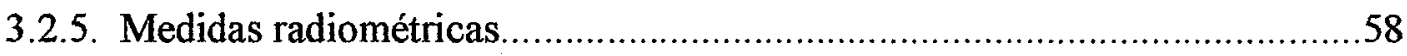

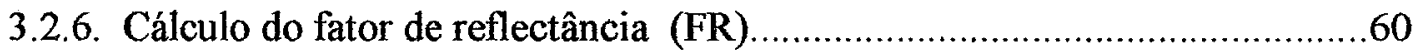

3.2.7. Cálculo do índice de vegetação diferença normalizada (NDVI) .................62

3.2.8. Estimativa da radiação fotossinteticamente ativa absorvida ( APAR) .........63

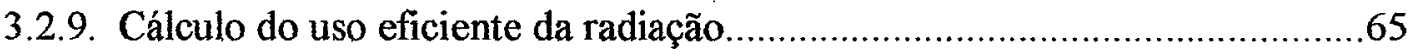

3.2.10.Produção e componentes de produção..........................................................66

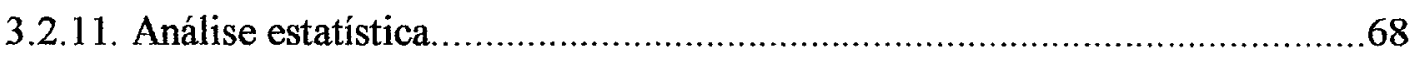

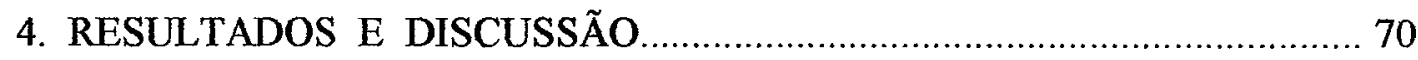

4.1. Análise do fator de reflectância das bandas $\mathrm{TM}_{3}$ e $\mathrm{TM}_{4}$ e do índice de vegetação diferença normalizada (NDVI) ....................................70

4.2. Estimativa da radiação fotossinteticamente ativa absorvida acumulada, e do uso eficiente da radiação para a produção de grãos.................................76

4.3. Análise da produção e dos componentes de produção.......................................81

5. CONCLUSÕES

REFERÊNCIAS BIBLIOGRÁFICAS........................................................... 90

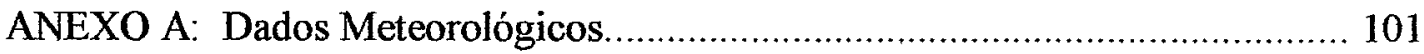

ANEXO B: Programa Computacional: Equação de Van Genutchen ................... 106 
ANEXO C: Dados do fator de reflectância correspondentes as bandas $\mathrm{TM}_{3}$ e $\mathrm{TM}_{4}$ e respectivos valores do índice de vegetação diferença normalizada,obtidos através da radiometria de campo

ANEXO D: Curvas de espectrometria de campo para a cultura do feijão aos 42 , 50 e 68 dias de idade e considerando as médias encontradas para o tratamento 4, o qual foi submetido a uma lâmina total de 373,40 mm durante todo o ciclo.

ANEXO E: Médias finais obtidas para as 24 parcelas analisadas e respectivos tratamentos, para o número de vagens por planta, número de grãos por vagem, comprimento da vagem, produtividade de grãos, altura média da planta, radiação fotossinteticamente ativa absorvida acumulada e para a eficiência do uso da radiação para a produção de grãos. 


\section{LISTA DE FIGURAS}

\section{Página}

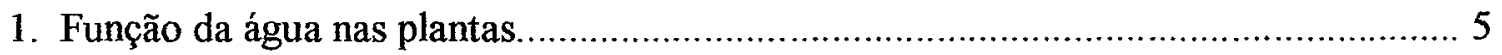

2. Regiões do espectro óptico.

3. Curva de irradiância solar

4. Estrutura morfológica de uma folha verde normal.

5. Ilustração esquemática das três grandes fases do ciclo fenológico de uma cultura agrícola, quanto aos principais componentes do sistema a influenciar a resposta espectral dos dosséis.

6. Curva média da vegetação fotossinteticamente ativa

7. Relação inversa entre reflectância de uma folha e absorcão de água

8. Curvas de reflectância espectral de folhas de plantas obtidas durante a fase de crescimento vegetativo e durante a senescência

9. Local de instalação do experimento, mostrando a cultura do feijão aos 35 dias após o plantio

10. Coleta de amostra indeformada do solo na profundidade de $30 \mathrm{~cm}$, através do emprego do anel volumétrico 
11. Distribuição da precipitação do aspersor FABRIMAR / Mod. A1823 $(6,0 \times 4,0 \mathrm{~mm})$, em função da distância da linha de aspersores.

12. Esquema de obtenção de medida da radiância para a aquisição do fator de reflectância do feijão em condições de campo 48

13. Esquema do delineamento experimental. 50

14. Sistema de irrigação convencional permitindo irrigações uniformes em todos os tratamentos, visando padronizar a germinação. Cultura aos 3 dias após o plantio 53

15. Tomada de dados radiométricos no campo 59

16. Fator de reflectância na banda $\mathrm{TM}_{3}$, obtido ao longo do ciclo da cultura do feijão, para os diferentes tratamentos utilizados.

17. Fator de reflectância na banda $\mathrm{TM}_{4}$, obtido ao longo do ciclo da cultura do feijão, para os diferentes tratamentos utilizados 72

18. Índice de vegetação diferença normalizada (NDVI), obtido ao longo do ciclo da cultura do feijão e para os diferentes tratamentos. .74 


\section{LISTA DE TABELAS}

Página

1. Diferentes tipos de radiação eletromagnética conhecidas, características e suas respectivas regiões espectrais. 16

2. Análise química do solo.

3. Características físicas do solo para a profundidade de $0-20 \mathrm{~cm}$.

4. Umidade volumétrica $\left(\theta, \mathrm{cm}^{3} / \mathrm{cm}^{3}\right)$ nas diversas tensões $\left(-\psi_{\mathrm{m}}, \mathrm{KPa}\right)$, nas profundidades de 20 e $30 \mathrm{~cm}$ do solo.

5. Etapas do desenvolvimento do feijão (fenologia), com os respectivos intervalos de tempo observados no experimento. 44

6. Lâminas aplicadas através da irrigação e precipitação pluvial (mm) ocorrida nos tratamentos $1,2,3$ e 4 .

7. Parâmetros referentes a determinação da curva de retenção de água do solo nas profundidades de 20 e $30 \mathrm{~cm}$ e extrapolados do método de Dourado Neto et al. (1990).

8. Datas em que foram obtidas no campo as medidas radiométricas do dossel da cultura do feijão e respectiva idade da cultura em dias.

9. Resumo da análise de variância da radiação fotossinteticamente ativa absorvida acumulada $\left(\mathrm{APAR}_{\mathrm{ac}}\right)$ 
10. Teste de Tukey para os resultados da média da radiação fotossinteticamente ativa absorvida acumulada $\left(\mathrm{APAR}_{\mathrm{ac}}\right)$

11. Resumo da análise de variância da eficiência do uso da radiação para a produção de grãos. 79

12. Teste de Tukey para os resultados da eficiência do uso da radiação para a produção de grãos..

13. Análise de variância para as médias dos tratamentos de altura média da planta (AP), número de vagens por planta (NVP), comprimento da vagem (TV), número de grãos por vagem (NGV) e produtividade de grãos (Grão) da cultivar de feijoeiro IAC - Carioca 80, obtida em função das lâminas de irrigação aplicadas. 


\section{LISTA de ABREVIATURAS E SÍMBOLOS}

A.P. - Altura média das plantas $(\mathrm{cm})$

APAR - Radiação Fotossinteticamente Ativa Absorvida ( $\mathrm{MJ} \mathrm{m}^{-2}$ )

$\mathrm{APAR}_{\mathrm{ac}}$ - Radiação Fotossinteticamente Ativa Absorvida Acumulada (MJ m ${ }^{-2}$ )

Banda - Faixa espectral de um canal de um instrumento de leitura de reflectância

FR - Fator de Reflectância

FRB - Fator de Reflectância Bidirecional

GRÃO - Produtividade de grãos (kg/ha)

IVP - Faixa do Infravermelho Próximo

IVM - Faixa do Infravermelho Médio

J - Joule

KPa - Kilo Pascal

NDVI - Índice de Vegetação Diferença Normalizada

$\mathrm{nm}$ - nanômetro $\left(10^{-9} \mathrm{~m}\right)$

N.G.V. - Número de grãos por vagem

N.V.P. - Número de vagens por planta

PAR - Radiação Fotossinteticamente Ativa ( $\mathrm{MJ} \mathrm{m}^{-2}$ )

PL - Parcela

sr - Sterradiano (unidade de ângulo)

T - Tratamento

TM - Tematic Mapper

$\mathrm{TM}_{3}$ - Fator de Reflectância medido na faixa espectral do vermelho (630 a $700 \mathrm{~nm}$ )

$\mathrm{TM}_{4}$ - Fator de Reflectância medido na faixa espectral do infravermelho próximo (760 a $900 \mathrm{~nm})$

T.V. - Comprimento da vagem $(\mathrm{cm})$

V - Faixa do Vermelho

W - Watt

$\varepsilon_{\mathrm{G}}-$ Eficiência do uso da radiação para a produção de grãos $\left(\mathrm{g} \mathrm{MJ}^{-1}\right)$ 
$\mu \mathrm{m}-10^{-6} \mathrm{~m}$

$\theta$ - Umidade Volumétrica do solo $\left(\mathrm{cm}^{3} / \mathrm{cm}^{3}\right)$

$\theta \mathrm{r}$ - Umidade Residual do solo $\left(\mathrm{cm}^{3} / \mathrm{cm}^{3}\right)$

$\theta s$ - Umidade de Saturação do solo $\left(\mathrm{cm}^{3} / \mathrm{cm}^{3}\right)$

$\psi$ - Potencial Mátrico da água no solo (KPa) 


\title{
COMPORTAMENTO ESPECTRAL E CARACTERÍSTICAS AGRONÔMICAS DA CULTURA DO FEIJÃO IRRIGADA COM DIFERENTES LÂMINAS DE ÁGUA
}

\author{
Autor: CARLOS AUGUSTO HUNGRIA DA CUNHA \\ Orientador: Prof. Dr. RUBENS ANGULO FILHO
}

\section{RESUMO}

A presente pesquisa teve por objetivo submeter a cultura do feijão a irrigação com diferentes lâminas de água, e analisar o efeito destas no seu comportamento espectral, na eficiência do uso da radiação fotossinteticamente ativa absorvida acumulada ( $\mathrm{APAR}_{\mathrm{ac}}$ ) para a produção de grãos, na produtividade obtida, e em alguns parâmetros agronômicos observados. Para isso, foi instalado um experimento no campo experimental da Escola Técnica em Agropecuária "ETAE Dr. José Coury", no município de Rio das Pedras - SP, e durante o período de 17/07/99 a 19/10/99. O delineamento experimental foi em blocos não casualisados, com a utilização de 4 tratamentos e 6 repetições, sendo as repetições em número de 3 de cada lado da linha de aspersores, perfazendo assim um total de 24 parcelas. A aplicação de água foi feita com auxílio de um sistema de irrigação por aspersão denominado "aspersão em linha". Os tratamentos constaram de quatro lâminas totais de irrigação, denominados de $\mathrm{T}_{4}(373,40$ $\mathrm{mm}), \mathrm{T}_{3}(288,40 \mathrm{~mm}) ; \mathrm{T}_{2}(206,40 \mathrm{~mm})$ e a testemunha $\mathrm{T}_{1}(164,40 \mathrm{~mm})$. No experimento foi utilizado o cultivar de feijoeiro IAC - Carioca 80, com ciclo de 90 a 100 dias do plantio à colheita. Foram realizadas no decorrer do experimento 10 medidas radiométricas nas faixas do visível e infravermelho próximo, utilizando o espectrorradiômetro SPECTRON SE-590, com a finalidade de se obter os valores do fator de reflectância nas bandas $\mathrm{TM}_{3}$ e $\mathrm{TM}_{4}$ e os valores do índice de vegetação diferença normalizada (NDVI), os quais foram posteriormente utilizados para estimar a 
radiação fotossinteticamente ativa absorvida acumulada $\left(\mathrm{APAR}_{\mathrm{ac}}\right)$, através da qual se calculou a eficiência do uso da radiação para a produção de grãos $\left(\varepsilon_{G}\right)$. De acordo com os resultados obtidos nesta pesquisa foi possível constatar que, as diferentes lâminas de água aplicadas afetaram o comportamento espectral da cultura do feijão nas bandas $\mathrm{TM}_{3}$ e $\mathrm{TM}_{4}$, variando porém em função do desenvolvimento da cultura. Assim, notou-se que para todos os tratamentos, ao aumentar o vigor da vegetação, aumentaram os valores de reflectância na banda $\mathrm{TM}_{4}$, ocorrendo o inverso com os valores de $\mathrm{TM}_{3}$. As diferentes lâminas de água também influenciaram significativamente a $5 \%$ de probabilidade a eficiência do uso da radiação para a produção de grãos $\left(\varepsilon_{\mathrm{G}}\right)$ da cultura, e foram as maiores lâminas que corresponderam aos maiores valores encontrados. A irrigação possibilitou ainda um aumento de cerca de $372 \%$ na produtividade de grãos, se considerado o tratamento testemunha. Tendo em vista os parâmetros agronômicos analisados, foi possível concluir que para todos eles, os maiores valores médios foram observados no tratamento correspondente a maior lâmina de água aplicada. 


\title{
SPECTRAL BEHAVIOR AND AGRONOMIC \\ CHARACTERISTICS OF BEAN CROP IRRIGATED \\ WITH DIFFERENT DEPTHS
}

\author{
Author: CARLOS AUGUSTO HUNGRIA DA CUNHA \\ Adviser: Prof. Dr. RUBENS ANGULO FILHO
}

\section{SUMMARY}

The present research had as a purpose to irrigate the bean crop with different depths and to analyze their effect on spectral behavior and accumulated absorbed photosynthetically active radiation $\left(\mathrm{APAR}_{\mathrm{ac}}\right)$ use efficiency for grain production, productivity and other agronomic parameters. An experiment was installed in the experimental field of the Technical Agricultural School " ETAE Dr. José Coury ", in Rio das Pedras, São Paulo State, Brazil during the winter season of 07/1999. The trial was not in randomized blocks, with 6 replicates for each of the 4 treatments, a total of 24 plots. The water application was done with an irrigation system denominated "line source sprinkler system". The treatments consisted of four depth irrigations, denominated T4 (373.40 mm), T3 (288.40 mm); T2 (206.40 mm) and T1 (164.40 mm), the control treatment. In the experiment, a bean cultivar named " IAC - Carioca 80 , with a cycle of 90 to 100 days from sowing to harvest was used. During the experiment, 10 spectrorradiometric measurements were carried out, in the visible and near infrared, using the espectroradiometer SPECTRON SE-590 aiming to obtain the values of the reflectance factor (FR) in the $\mathrm{TM}_{3}$ and $\mathrm{TM}_{4}$ bands, and the values of the normalized difference vegetation index (NDVI). Both of them were used to calculate the accumulated absorbed photosynthetically active radiation $\left(A P A R_{a c}\right)$. And this value was 
used to calculate the radiation use efficiency for grain production $\left(\varepsilon_{\mathrm{G}}\right)$. In agreement with the results obtained in this research, it was possible to verify that the different irrigation depths affected the spectral behavior of the bean crop in the $\mathrm{TM}_{3}$ and $\mathrm{TM}_{4}$ bands, varying due to the crop development. Thus, for all the treatments, when the vegetation vigor increased, it increased the reflectance values in the $\mathrm{TM}_{4}$ band, the opposite happened with the $\mathrm{TM}_{3}$ values. The different irrigation depths influenced significantly the radiation use efficiency for grain production $\left(\varepsilon_{G}\right)$, and the largest irrigation depth correspondent to the largest values found at the probability level of $5 \%$. The irrigation also increased the grain productivity to $372 \%$ when compared to the control. In relation to the analyzed agronomic parameters, the largest medium values were observed in the treatment that used the largest irrigation depth. 


\section{INTRODUÇÃO}

Nenhum produto agrícola brasileiro ostenta uma situação tão absurda como o feijão. Primeiro alimento na preferência popular, o feijão continua ainda sendo a cultura tecnologicamente mais atrasada do país. Segundo dados fornecidos por Costa (1987), observa-se que sua produtividade vem caindo há mais de quarenta anos, quando apresentava produtividade média igual a $800 \mathrm{~kg} / \mathrm{ha}$ (década de 40), diminuindo para cerca de $400 \mathrm{~kg} /$ ha no final da década de 80 , situação esta que permanece inalterada até os dias de hoje.

Baixa remuneração ao produtor, elevado risco climático, substituição de áreas cultivadas por plantios de exportação ou de produção de biomassa para combustivel, baixos investimentos em pesquisa, descaso total com que a política agrícola trata o produto; são muitas as causas que levaram ao desinteresse por sua cultura. Atraídos por alternativas mais rentáveis, grandes e médios produtores abandonaram a cultura, deixando-a aos cuidados do pequeno produtor.

O uso de sementes sadias, adubação adequada, tratos culturais compatíveis e o emprego de sistemas de irrigação eficientes para corrigir deficiências hídricas nas regiões de pouca disponibilidade de água ou de precipitação, ou ainda para o cultivo de inverno nas regiões tradicionais, significaria um avanço de várias décadas nesse quadro, com um aumento bastante significativo na produção e na produtividade dessa cultura.

Vários autores (Caixeta, 1978; Garrido et al., 1979; Azevedo, 1984; Costa, 1987; Paz et al., 1997 ) têm demonstrado a viabilidade da irrigação do feijão de inverno, sendo possível obter produtividades consideradas muito superiores às tradicionais, além da estabilidade na produção, pois ocorre a eliminação das incertezas relativas às chuvas. 
Sabe-se ainda que, com o avanço da tecnologia e a necessidade de obtenção de produtividades cada vez maiores, bem como um maior controle sobre os fatores que influenciam o pleno desenvolvimento da cultura do feijão, tornou-se necessário estimar algumas das variáveis da cultura relacionadas com as suas condições, de forma a se obter dados de entradas para alguns modelos de crescimento e de produtividade agrícola que existem atualmente e de grande importância para todo esse processo. Porém, nota-se que os modelos de crescimento/produtividade para as principais culturas e para a cultura do feijão, são baseados em dados meteorológicos, que são dados pontuais, de coleta trabalhosa e que não levam em consideração vários fatores como as condições do solo, clima, pragas, doenças, nutrientes, etc., possibilitando assim uma margem muito grande de erros na avaliação final. Assim sendo, a utilização de algumas técnicas de sensoriamento remoto e particularmente a utilização de dados espectrais, podem suprir essa carência e servir como excelentes indicadores das condições gerais de vigor da cultura do feijão, principalmente para áreas grandes e contínuas, podendo ainda servir como parâmetros de entrada para melhorar o desempenho dos modelos existentes.

Alguns trabalhos publicados na literatura (Gallo et al., 1985; Prince, 1991; Moreira, 1997; entre outros) atestam que em plantas sadias e adequadamente supridas de água e nutrientes, existe uma relação linear positiva entre a quantidade de radiação fotossinteticamente absorvida pelo dossel (APAR) e a produção final de fitomassa e grãos; dessa forma, as técnicas de sensoriamento remoto procuram estabelecer uma relação entre a radiação solar absorvida pelo dossel da cultura e as interações com seus atributos biofísicos, criando dessa maneira alguns modelos para estimativas de produção de fitomassa e de grãos.

Devido ainda a impossibilidade da quantificação da APAR e de forma direta, torna-se necessária a utilização de alguns modelos matemáticos para esse fím, sendo que a estimativa da APAR através de índices de vegetação e obtidos através de medidas do fator de reflectância nas bandas espectrais do vermelho (V) e do infravermelho próximo (IVP), tem sido preferencialmente estudada e empregada nos dias de hoje, apresentando uma série de vantagens sobre os outros processos conhecidos. 
Sabe-se também que a caracterização de alvos agrícolas por meio de dados espectrais coletados por sensores a bordo de satélites orbitais é passível de uma série de erros amostrais, devido principalmente a complexidade do comportamento espectral do dossel agrícola. Dessa forma, evidencia-se a importância da realização de coletas radiométricas a nível de campo e envolvendo diretamente a planta, o solo e os fatores ambientais, tal qual realizada no presente experimento, obtendo-se assim informações no próprio local de estudo e que poderão servir para melhorar ainda mais o processo de caracterização desses alvos.

É neste contexto que se insere esta pesquisa, assumindo-se a hipótese de que variáveis espectrais e variáveis agronômicas guardam íntimas relações entre si e que os parâmetros espectrais podem ser utilizados, quando manipulados corretamente, como descritores das condições gerais de vigor e de desenvolvimento do feijoeiro.

Pretende-se também verificar a hipótese de que variáveis agronômicas como produtividade de grãos; altura da planta; número de vagens por planta; tamanho das vagens e número de grãos por vagem podem ser influenciadas pela lâmina de água aplicada. 


\section{REVISÃO DE LITERATURA}

\subsection{Importância da água na produção agrícola}

Do total da água existente no globo terrestre $\left(1,24 \times 10^{18} \mathrm{~m}^{3}\right)$ calcula-se que somente $0,35 \%$ corresponde a água doce situada na superficie ou como água subterrânea economicamente aproveitável, por situar-se até uma profundidade de $800 \mathrm{~m}$; sendo que o Brasil possui 8\% da água doce da Terra (Olitta, 1988).

A água é essencial para a vida e, por isso, está presente em toda parte. As culturas agrícolas precisam dela porque a água entra na sua composição; transporta do solo até as raízes os nutrientes minerais e ajuda a planta a suportar melhor o intenso calor provocado pelo sol, refrescando o ambiente em que suas raízes se desenvolvem. Assim sendo, a planta sofre quando o solo não tem água suficiente para atender suas necessidades ou quando a perda de água pelas folhas é tão rápida que as raízes não tem tempo de absorver a água disponível no solo. O prejuízo é maior ainda se a falta de água afeta a formação dos grãos ou dos frutos; se faltar água nesse período crítico observamos que a produção agrícola e a produtividade da área reduzem-se a ponto de por em risco a agricultura como atividade economicamente viável (Costa, 1987).

Não pode existir vida em ausência da água; esta é de vital importância para as plantas pois é veículo de transporte de nutrientes para os vegetais; a água dá turgidez aos tecidos e mantém em equilíbrio a temperatura na planta; ela transporta como seiva, os nutrientes para todas as partes da planta (Galeti, 1982).

O Programa Nacional de Irrigação (1988), cita que a manutenção do fluxo de água através da planta é condição essencial para o seu normal desenvolvimento e por 
diversas razões dadas a seguir: (a) a água é um meio de transporte de substâncias necessárias à composição da planta, chamadas nutrientes minerais. Estes nutrientes movimentam-se do solo para as plantas através da água que é absorvida pelas raízes, (b) a água também exerce sobre a planta uma função refrigeradora, c) uma certa quantidade de água participa da composição da planta, combinando assim com outros materiais essenciais ao seu desenvolvimento, tal como mostra a Figura 1.

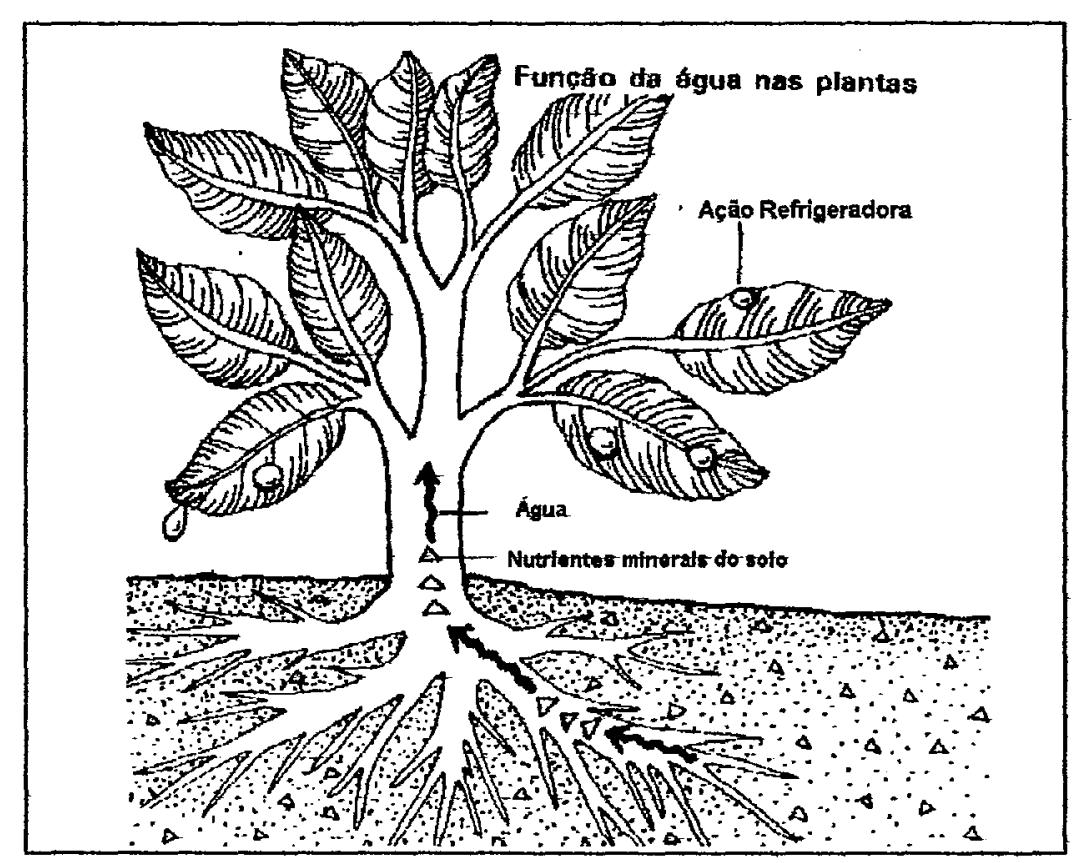

Figura 1 - Função da água nas plantas. Fonte: Costa (1987).

Considerando ainda os efeitos da diminuição de umidade na planta, esta realiza uma série de respostas à falta desta, que são reações de proteção contra as condições desfavoráveis à sua sobrevivência. A resposta mais importante refere-se à redução da transpiração ou à perda de água pelas folhas, evitando assim o seu murchamento. Uma planta murcha é uma planta seriamente danificada e, embora a irrigação após o murchamento possa recuperar uma planta, ela não pode impedir a ocorrência de danos ao seu crescimento. A diminuição da umidade, por falta de água prolongada no solo, pode afetar as seguintes funções essenciais da planta: (a) fotossíntese: diminuição da sua intensidade, (b) nutrição mineral: diminuição do fenômeno de absorção de minerais 
pelas raízes da planta, (c) crescimento das raízes: empobrecimento de seu desenvolvimento e engrossamento de sua casca, diminuindo a eficiência de absorção, (d) crescimento: retarda o crescimento da planta e (e) floração e frutificação: sofrem grande influência do clima quanto ao suprimento de água no solo sendo que uma falta prolongada provoca a queda das flores e dos frutos já formados (Programa Nacional de Irrigação, 1988).

Tibau (1986), cita que a água pelo seu comportamento físico é fator imprescindível a vida em geral, sendo que para os vegetais, constitui-se também em parte integrante da formação de alimentos. Segundo o autor é por esse motivo que a prática de agricultura impõe, para segurança do seu êxito, o suprimento de água onde quer que falte ou seja insuficiente. Essa é a razão pelo qual no ocidente, na região onde se formaram as primeiras aglomerações humanas, a carência ou irregularidades pluviométricas obrigou-as a construírem grandes obras hidráulicas, destinadas ao fornecimento supletivo ou essencial desse líquido.

Blauth (1982), comenta que são inúmeros os experimentos científicos provando as vantagens da irrigação para as plantas. $O$ autor cita entre as vantagens principais: (a) a irrigação é um seguro contra a seca: forma de cobrir as oscilações pluviométricas, (b) permite um aumento significativo da produção: culturas dobram a produtividade com o simples uso da irrigação, (c) melhora a qualidade do produto: a produção fica acrescida em sua aparência e constituição, (d) a irrigação propicia uma desalinização necessária: a água, percolando por entre os poros, arrasta consigo os sais acumulados no solo, (e) a irrigação aumenta a resistência vegetal: aumenta o potencial de defesa da planta ao enfrentar o agente que the faz ataque, (f) a irrigação amplia o periodo de produção.

Kay (1986) e Vieira (1989), concluem que a irrigação pode ser uma técnica obrigatória ou suplementar mas trata-se de uma técnica absolutamente necessária para a implantação de uma agricultura racional em regiões de clima árido e semi-árido, nas quais a quantidade total de chuva precipitada no ano é insuficiente para satisfazer as necessidades hídricas dos cultivos. Segundo ainda os autores, a irrigação pode também 
ser uma técnica obrigatória em outras regiões onde os totais anuais de precipitação pluviométrica não são limitantes à agricultura.

A irrigação é uma das mais importantes tecnologias empregadas para aumentar a produtividade, permitir maior eficiência e estabilidade na produção agrícola. Ela é imprescindivel para regiões com baixas precipitações pluviométricas e importante para aquelas em que ocorre com freqüência, mas sujeitas a estiagens ou veranicos (Maia, 1994).

\subsection{Efeito da irrigação na cultura do feijão}

Estudando cinco regimes hídricos na cultura do feijão em lisímetros, Maurer et al. (1969), observaram que a produção de feijão é dependente de um regime adequado de água na fase de desenvolvimento das vagens e que para a maximização da produção é necessário também um adequado regime de água na fase de pré-florescimento. As plantas que foram irrigadas quando o solo apresentava $88 \%$ da água disponível, ficaram mais altas, mais pesadas e produziram maior número de vagens que as plantas irrigadas quando a água disponível do solo atingiu um valor de $60 \%$. As plantas irrigadas quando o solo alcançou $32 \%$ da água disponível, ficaram menores e produziram menos que todos os tratamentos irrigados.

Analisando o potencial de produção do feijão irrigado no norte de Minas Gerais, Garrido et al. (1979), instalaram um ensaio com três níveis de irrigação com reposição da água quando a umidade do solo atingisse $20 \%, 40 \%$ e $80 \%$ da água disponível; notaram os autores que a maior produtividade de grãos foi obtida com o tratamento cuja reposição de água era feita quando se atingia $80 \%$ da água disponível do solo.

Estudando o comportamento da cultura do feijão sob três regimes de irrigação, Mack \& Bonanno (1981), concluem que no tratamento menos irrigado com 63,5 mm de água e no tratamento intermediário com $116,84 \mathrm{~mm}$, durante o ciclo completo da cultura, a produção foi menor que no tratamento mais irrigado, o qual recebeu $241,3 \mathrm{~mm}$ 
durante o ciclo. $\mathrm{O}$ número de vagens por planta foi muito baixo nos tratamentos seco e intermediário ; a produtividade do tratamento mais irrigado foi de 7 e 6 vezes maior que os tratamentos seco e intermediário.

Quanto as lâminas para a obtenção da máxima produtividade de grãos, inúmeros trabalhos (Caixeta, 1978; Silva, 1982; Frizzone, 1986; Garrido et al., 1979; Cardoso et al., 1997) revelaram que estas variam de $370 \mathrm{~mm}$ a $570 \mathrm{~mm}$ com reflexo direto na produtividade de grãos de $1376,00 \mathrm{~kg} / \mathrm{ha} \mathrm{a} 2905,00 \mathrm{~kg} / \mathrm{ha}$.

Para Azevedo (1984), o feijão é uma cultura sensível à falta de água, sendo este fator um dos mais importantes para a obtenção de altas produtividades. Verificando o efeito de diferentes lâminas de água a vários níveis de adubação nitrogenada sobre a produtividade e componentes de produção da cultura do feijão cultivar Carioca, concluiu que a irrigação possibilitou aumento de produtividade em relação ao tratamento não irrigado de 76,7\%; a produtividade máxima foi de $905 \mathrm{~kg} /$ ha para uma lâmina de 394 $\mathrm{mm}$. Observou o autor um efeito significativo com o aumento das lâminas totais de água nos seguintes componentes de produção analisados: número de grãos por vagem, peso de grãos por vagem e número de grãos por planta. Observou ainda que o peso de 100 sementes em todas as doses de nitrogênio diminuiu linearmente com o aumento da lâmina total de água; a menor lâmina total de água correspondente a $320 \mathrm{~mm}$ foi a que apresentou o maior peso de 1000 sementes.

Em relação à freqüência de irrigação na cultura do feijão, e usando-se o sistema de irrigação por aspersão, Silveira et al. (1984), comentam que a medida em que as irrigações são mais freqüentes, a produção é maior, porém o custo da irrigação aumenta, sendo que um turno de rega de quatro a sete dias tem-se mostrado satisfatório. Segundo os autores, o uso de alta frequiência de irrigação (dois dias) na cultura do feijão, não apresenta nenhuma vantagem quando comparada com a irrigação em turno de sete dias (primeiro ano) e doze dias (segundo ano).

Analisando a cultura do feijão irrigado, Costa (1987), afirma que o consumo de água por parte do feijão, depende principalmente das condições climáticas locais, das características físico-hídricas dos solos e da cultivar usada e que durante o decorrer do 
ciclo as exigências hídricas se alteram. Assim, nas fases iniciais da cultura, num período relativamente curto após o plantio, esse consumo é pequeno (da germinação até a cobertura de $10 \%$ do terreno pela planta). Em seguida vem a fase de desenvolvimento vegetativo (desde $10 \%$ até $100 \%$ da cobertura do terreno pelo vegetal), onde uma severa deficiência de água geralmente retarda o desenvolvimento da planta e poderá causar um crescimento irregular. Após, seguem as fases de florescimento e formação dos grãos, as quais são consideradas críticas para a produção pois o consumo de água pela cultura nestas fases é máximo (consumo de pico ou evapotranspiração máxima). Uma deficiência hídrica no período crítico compromete, em muito, o rendimento produtivo devido principalmente à redução do número de vagens por planta e em menor escala, à diminuição do número de sementes por vagem. Estabelece ainda que a variação do consumo de água para a máxima produção da cultura do feijão poderá variar entre 300 a $500 \mathrm{~mm}$ por ciclo, dependendo de alguns fatores como a duração do período de desenvolvimento da cultura, a região e o clima a que está exposta.

De acordo com Fancelli (1987), a cultura do feijão exige um mínimo de 250 $\mathrm{mm}$ de precipitação para que produza a contento, sem a necessidade da prática de irrigação. Assim sendo, regiões cujas precipitações oscilem entre $250 \mathrm{~mm}$ a $500 \mathrm{~mm}$ anuais são consideradas aptas para o plantio da mencionada espécie, embora tal limitação encontre-se mais diretamente condicionada à distribuição, do que à quantidade total de chuvas ocorrida no período. Segundo ainda o autor, o consumo de água por parte do feijão, raramente excede $3,0 \mathrm{~mm} / \mathrm{dia}$, enquanto a planta estiver no início de desenvolvimento; todavia, no período compreendido entre o florescimento e a maturação, o consumo pode se elevar para $4,0-4,5 \mathrm{~mm} /$ dia. Ressalva ainda que outros dados experimentais referentes a essa cultura, evidenciam índices diários de consumo de água próximos a $5 \mathrm{~mm}$, quando as plantas encontram-se submetidas a condições de intenso calor e baixa umidade relativa do ar.

Reichardt (1990), estabelece que por possuir cerca de 90\% do seu sistema radicular nos primeiros $25 \mathrm{~cm}$ do solo, responde o feijão muito bem à irrigação com um grande aumento da produtividade. A necessidade de água da cultura durante todo o seu 
ciclo se situa entre 300 a $500 \mathrm{~mm}$, sendo que o período crítico está situado nas fases de floração e formação de vagens, de forma que um déficit hídrico neste momento, reduz drasticamente a produtividade.

Pesquisando a cultura do feijão irrigado, Libardi \& Saad (1994), realizaram um experimento de campo em Latossolo roxo na região de Guaíra, São Paulo, utilizando o cultivar Carioca, o qual foi plantado no inverno com um espaçamento de $53 \mathrm{~cm}$ entre as linhas e irrigado por 16 vezes até o final do ciclo. O gradiente de potencial da água do solo e a condutividade hidráulica foram medidas ao longo do crescimento da cultura, através de tensiômetros instalados a uma profundidade de $15 \mathrm{~cm}$ e $30 \mathrm{~cm}$. A drenagem interna foi desprezivel ao longo de crescimento, e as produtividades médias obtidas foram de $3,03 \mathrm{t} / \mathrm{ha}$, o que evidenciou o sucesso do método escolhido. Afirmam os autores que o monitoramento da exigência de irrigação através de tensiômetros foi eficiente, e a irrigação do feijão através de pivô-central foi apropriada.

Segundo Queiróz et al. (1996), no planejamento da irrigação o elemento básico a ser considerado é a resposta da cultura a água. As plantas do feijão respondem muito bem à quantidade e à freqüência das irrigações durante praticamente todo o seu ciclo de desenvolvimento, resultando em alterações no rendimento.

\subsection{Efeito de estresse hídrico na cultura do feijão}

A cultura do feijão é bastante sensível ao déficit hídrico em determinadas fases de seu ciclo. Diversos pesquisadores ao estudar o comportamento do feijão submetido ao déficit hídrico em diferentes fases de desenvolvimento, observaram que durante o florescimento e a formação de vagem, a falta de água acarreta diminuição na produção de grãos. Assim sendo, estas fases foram consideradas críticas por estes, de forma que um déficit hídrico acarretaria em reduções drásticas na produção de grãos.

Para Caixeta (1978), vários trabalhos de pesquisa, indicam que as fases de florescimento e início de frutificação do feijão constituem os períodos críticos, em que a falta de água pode ocasionar perdas bastante significativas. Na Região Norte de Minas 
Gerais, constatou que quando ocorria déficit de água no início da floração, no final da floração e na formação e crescimento das vagens, a produção diminuía cerca de $16 \%$, $42 \%$ e $58 \%$ respectivamente, em relação ao tratamento onde não havia déficit.

Turner \& Begg (1981), observaram que o efeito do déficit hídrico provoca uma redução na razão fotossintética, que por sua vez provoca uma redução na translocação de metabólitos, o que influencia consideravelmente nos processos produtivos, refletindo-se de maneira marcante no rendimento de grãos de feijão.

Pesquisando a cultura do feijão irrigado, Costa (1987) comenta que, tendo em vista à necessidade de água nos diferentes estágios do feijoeiro, são a floração e o enchimento das vagens as chamadas fases críticas. Segundo o autor, pode haver uma queda de $20 \%$ ou mais no rendimento de grãos de sementes, quando ocorre falta de água no solo quinze dias antes da floração ou de dezoito a 22 dias durante a floração, ou ainda quinze dias antes da maturação das primeiras vagens. Afirma ainda que a falta de umidade antes da floração diminuiu o número de vagens; se esta ocorre durante a floração, não só o número de vagens se reduz mas também o número de sementes por vagem; na fase de maturação provocará uma diminuição no peso das sementes.

Segundo Fancelli (1987), para o feijoeiro, as maiores exigências em umidade se concentram nas fases de emergência, florescimento e formação das vagens. Informa ainda que para alguns autores, a ocorrência de ligeiros déficits hídricos no início do desenvolvimento da cultura podem concorrer para estimular um maior desenvolvimento radicular das plantas, porém, deficiências posteriores poderão se tornar limitantes quando coincidentes com a fase de florescimento pois períodos de déficits hídricos de uma semana por ocasião da floração, podem promover queda de produção total.

O Programa Nacional de Irrigação (1988), cita que o consumo de água por parte do feijão depende principalmente das condições climáticas locais, das características físico-hídricas dos solos e da cultivar usada. Assim sendo, durante o decorrer do ciclo as exigências hídricas se alteram. Nas fases iniciais da cultura e num período relativamente curto após o plantio, esse consumo é pequeno (da germinação até a cobertura de $10 \%$ do terreno pela planta). Em seguida vem a fase de desenvolvimento 
vegetativo (desde $10 \%$ até $100 \%$ da cobertura do terreno pelo vegetal), onde uma severa deficiência de água geralmente retarda o desenvolvimento da planta e poderá causar um crescimento irregular. Após se seguem as fases de florescimento e formação dos grãos, as quais são consideradas críticas para a produção pois o consumo de água pela cultura nestas fases é máximo (consumo de pico ou evapotranspiração máxima). Uma deficiência hídrica nesse período crítico compromete em grande escala o rendimento produtivo, devido principalmente à redução do número de vagens por planta, e em menor proporção à diminuição do número de sementes por vagem.

Fancelli (1992), analisando o efeito do déficit hídrico nos diferentes estádios de desenvolvimento do feijão, conclui que no estádio $\mathrm{V}_{0}$ (germinação), o feijão possui grande sensibilidade à falta de água após a semeadura e valores superiores a 3,5 atm podem reduzir drasticamente a germinação. No período compreendido entre os estádios $V_{1}$ a $V_{3}$ (da emergência à emissão da primeira folha trifoliada), a planta apresenta maior tolerância a estresses hídricos e baixas temperaturas, porém, em níveis não muito acentuados. No estádio $V_{4}$ (emissão da terceira folha trifoliada), déficits hídricos neste período poderão restringir significativamente o porte e o índice de área foliar do feijão; sendo que o estádio $R_{5}$ (início da fase reprodutiva), pode ser considerado como uma das fases mais críticas quando há falta de água. Segundo o autor, no estádio $\mathbf{R}_{6}$ (florescimento), um déficit hídrico seria o responsável por perdas na produção ao redor de $48 \%$; sendo que se este ocorresse no estádio $R_{7}$ (início da formação das vagens), proporcionaria a redução da produção pela queda de vagens e pela diminuição do tamanho destas. Conclui ainda que no estádio $R_{8}$ (enchimento das vagens), a falta de água poderá concorrer para a diminuição da produção, influenciando o número e peso dos grãos; porém, o estádio $R_{9}$ (maturação), exige a baixa disponibilidade de água.

De acordo com Moreira et al. (1996), a redução no rendimento de grãos do feijão, pela ocorrência de deficiência hídrica durante o período reprodutivo, é ocasionada pela alta percentagem de abcisão das flores e abortamento de óvulos, reduzindo o número de sementes por vagem, sendo este o componente do rendimento mais afetado pelo déficit hídrico. Magalhães \& Millar (1978); Hostalácio \& Válio (1984), também 
afirmam que o número de sementes por vagem é mais afetado pelo déficit hídrico no período reprodutivo do que os demais componentes do rendimento de grãos do feijão.

Estudando a cultura do feijão irrigado, Paz et al. (1997), concluíram que o déficit de umidade no período que se estende da floração ao início da formação das vagens é o que mais acarreta perdas na produtividade, sendo seguido pelos déficits na pré-floração e na fase de maturação. Segundo os autores, o efeito do déficit hídrico sobre o crescimento e a produção depende do grau de estresse (intensidade e duração) e do estado de desenvolvimento vegetal; assim sendo, a existência de 10 e de 17 dias de déficit na fase reprodutiva, causam reduções de $42,6 \%$ e de $62,0 \%$ na produtividade. Afirmam ainda que os parâmetros de produção também variam significativamente quando a cultura é submetida a déficit hídricos, sendo que a produção de grãos e o número de vagens por planta são os parâmetros que apresentam maior sensibilidade.

Cardoso et al. (1997), ao testarem diferentes cultivares de feijão caupi, confirmam a proposição de que o componente número de vagens por planta foi diretamente influenciado pelas várias lâminas de água aplicadas e, consequentemente, aquele que mais contribui para o aumento de produtividade de grãos em todos os cultivares testados; notaram ainda os autores ao analisarem a característica agronômica comprimento da vagem, que as diferenças observadas deveram-se unicamente a fatores inerentes à própria cultivar.

\subsection{Sensoriamento remoto}

Segundo Simonetti (1983), sensoriamento remoto é a aquisição de informações sobre um objeto, sem que haja um contato físico.

Para Novo (1995), sensoriamento remoto é a utilização conjunta de modernos sensores, equipamentos para transmissão de dados, aeronave, etc, com o objetivo de estudar o ambiente terrestre através do registro e análise das interações entre radiação eletromagnética e as substâncias do planeta Terra em suas mais diversas manifestações.

A base teórica da identificação de objetos por sensoriamento remoto parte do 
princípio que cada objeto tem uma característica única de reflexão e emissão de energia eletromagnética. Com isto, o sensoriamento remoto pode identificar e entender o objeto ou condições ambientais através dessa unicidade de comportamento. Isso significa que dois objetos diferentes interagirão distintamente com a energia eletromagnética, se não em todos, pelo menos em alguns comprimentos de onda, permitindo assim sua identificação e diferenciação (Novo, 1995).

Jackson \& Huete (1991), afirmam que o fluxo radiante ao atingir a superficie dos objetos (alvos), sobre a superficie terrestre, interage com os mesmos resultando num fracionamento da seguinte maneira: (a) uma parte do fluxo é refletido, (b) outra parte do fluxo é absorvido pelos elementos da superficie do objeto e, (c) quando o objeto ou alvo é transparente à radiação solar, uma parte do fluxo é transmitido, através do objeto. As quantidades relativas de cada uma dessas partes, depende da superficie e varia com o comprimento de onda.

Segundo ainda os autores, esse fracionamento pode ser expresso de acordo com a seguinte equação do balanço de energia:

$$
\phi_{\mathrm{i}}=\phi_{\mathrm{r}}+\phi_{\mathrm{a}}+\phi_{\mathrm{t}}
$$

em que: $\phi_{\mathrm{i}}, \phi_{\mathrm{r}}, \phi_{\mathrm{a}}$ e $\phi_{\mathrm{t}}$ são os fluxos radiante incidente, refletido, absorvido e transmitido.

Normalizando a Equação (1) em relação ao fluxo incidente $\left(\phi_{i}\right)$, teremos a equação:

$$
1=\rho+\alpha+\tau
$$

em que as razões adimensionais: $\rho$ é denominada de reflectância; $\alpha$ de absortância e $\tau$ denominada de transmitância, cujos valores definem as propriedades radiométricas dos alvos analisados. 
Analisando ainda de uma forma geral as aplicações de sensoriamento remoto em agricultura e áreas afins, nota-se que existe uma série de pesquisas sobre o assunto, sendo que a maior parte destas logrou êxito nos objetivos traçados. Novo (1995), cita algumas destas aplicações: (a) avaliação dos recursos hídricos de uma região e parâmetros relacionados; (b) análise e monitoramento do uso da terra, mapeamento do uso da terra; (c) avaliação de fatores diretamente ligados a agricultura, tais como: levantamento e caracterização dos solos; estimativa de safras agrícolas; identificação de culturas e da área ocupada por estas; físcalização de operações de créditos agrícolas; monitoramento da vegetação com $o$ intuito de se avaliar entre outros as áreas desmatadas, queimadas ou degradadas; avaliação de eficiência de equipamentos e implementos usados nas culturas; discriminação de áreas de reflorestamento de Pinus e Eucaliptus; avaliação de danos causados por geadas, queimadas e pela incidência de pragas sobre a vegetação; etc.

\subsection{Radiação eletromagnética}

A radiação eletromagnética nada mais é que um feixe de energia eletromagnética que transmite a oscilação do campo eletromagnético através do espaço e da matéria. Ela pode ser considerada como uma onda transversal com campos elétrico e magnético associados.

Steffen (1996a), cita que quase toda a energia disponível na terra tem sua origem no Sol, de onde se propaga para todo o espaço em forma de radiação eletromagnética; esta por sua vez se desloca na forma de ondas e com uma velocidade próxima de 300.000 $\mathrm{km} / \mathrm{s}$. Os diferentes tipos de radiação eletromagnética podem ser equacionados através da caracterização de sua velocidade de propagação $(C)$, seu comprimento de onda $(\lambda)$ e sua freqüência (f), conforme descrito na Eq. (3):

$$
\mathrm{C}=\lambda . \mathrm{f}
$$


em que: C é a velocidade de propagação $(\mathrm{m} / \mathrm{s}) ; \lambda$ é o comprimento de onda $(\mathrm{m})$ e $\mathrm{f}$ a freqüência (hertz).

O conjunto dos diferentes tipos de radiações eletromagnéticas conhecidas recebe o nome de espectro eletromagnético. A Tabela 1, mostra o espectro eletromagnético no sentido dos maiores comprimentos de onda e as características principais de cada um dos tipos de radiação que o compõem.

Tabela 1. Diferentes tipos de radiação eletromagnética conhecidas, características e suas respectivas regiões espectrais. Base: Steffen (1996a).

\begin{tabular}{|c|c|c|}
\hline Tipo de Radiação & Características & Faixas \\
\hline Radiação Gama & $\begin{array}{l}\text { Alta energia; materiais radioativos. } \\
\text { Uso: medicina (radioterapia) e } \\
\text { na radiografia industrial. }\end{array}$ & $<0,1 \mathrm{~nm}$. \\
\hline Raios-X & $\begin{array}{l}\text { Freamento de elétrons de alta energia; } \\
\text { Uso: medicina (radioterapia) e também } \\
\text { no controle industrial. }\end{array}$ & $0,1-10 \mathrm{~nm}$ \\
\hline Ultravioleta & $\begin{array}{l}\text { Emitida em grande quantidade pelo sol } \\
\text { e atenuada pela camada de ozônio. }\end{array}$ & Faixa de $100-380 \mathrm{~nm}$ \\
\hline Visivel & $\begin{array}{l}\text { Radiações percebidas pelo olho } \\
\text { humano (luz). As cores são função } \\
\text { do comprimento de onda; cores } \\
\text { primárias: azul, verde e vermelho. }\end{array}$ & Faixa entre 380 a $720 \mathrm{~nm}$. \\
\hline Infravermelho & $\begin{array}{l}\text { Regiấo de importância para o } \\
\text { estudo da radiometria. }\end{array}$ & $\begin{array}{l}\text { *I.V. Próximo: } 720 \mathrm{~nm} \text { a } 1300 \mathrm{~nm} . \\
\text { "I.V. Médio: } 1300 \text { a } 3000 \mathrm{~nm} . \\
\text { * Região näo definida: } 3000 \text { a } 7000 \mathrm{~nm} \text {. } \\
\text { "I.V. Distante: } 7000 \text { a } 15000 \mathrm{~nm} \text { (termal) }\end{array}$ \\
\hline Microondas & $\begin{array}{l}\text { Radiaçōes produzidas por } \\
\text { sistemas eletrônicos. }\end{array}$ & $\begin{array}{l}\text { Faixa de } 1 \mathrm{~mm} \text { até } 1 \mathrm{~m} \text {. } \\
\text { Utilizadas nos sistemas de radar. }\end{array}$ \\
\hline
\end{tabular}


Vettorazzi (1992), cita que a faixa espectral mais usada em sensoriamento remoto é aquela que vai de $300 \mathrm{~nm}$ a $15000 \mathrm{~nm}$ (Figura 2). Essa região é conhecida como Espectro Óptico (região óptica) e se caracteriza pela existência de sensores que operam nesta faixa e que se utilizam de componentes óticos na sua construção (espelhos, prismas, lentes.), como as máquinas fotográficas e radiômetros.

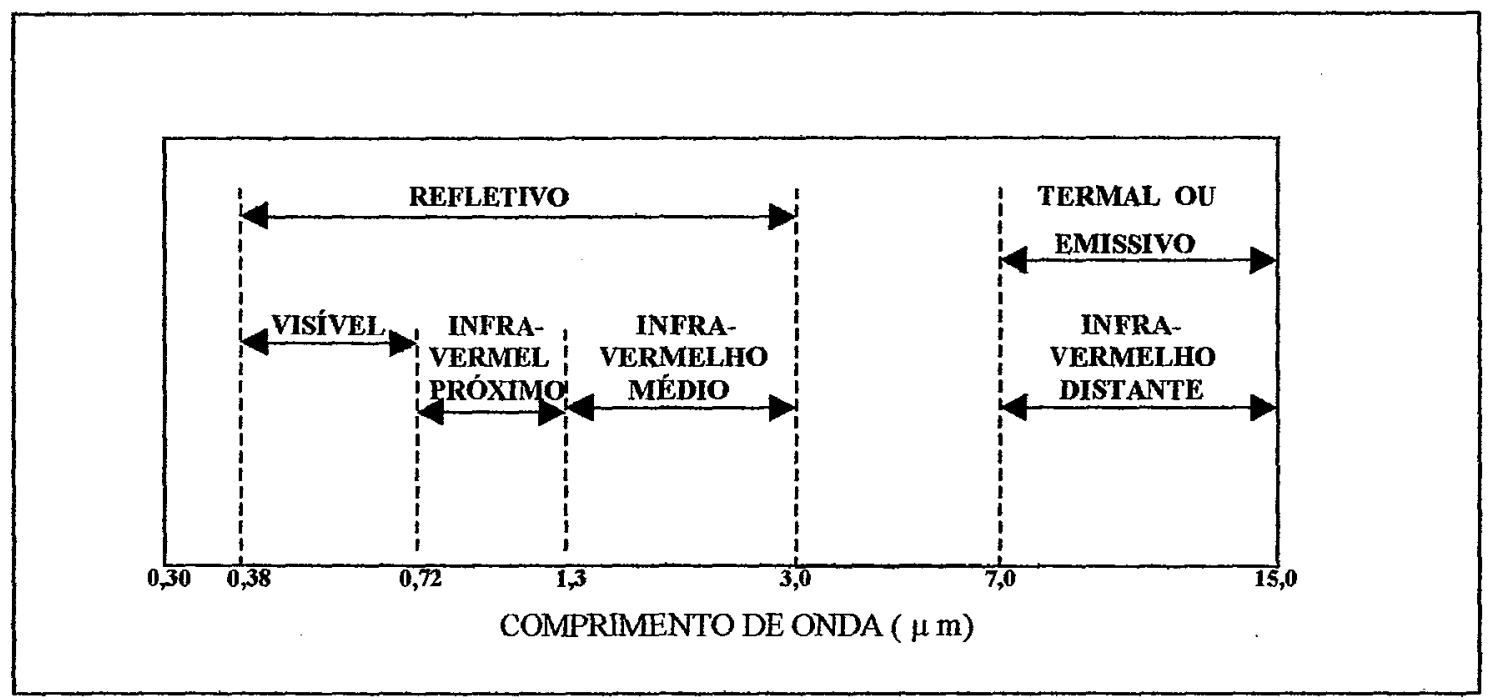

Figura 2 - Regiões do espectro óptico. Fonte: Swain \& Davis, (1978).

Moreira (1997), afirma que do ponto de vista do sensoriamento remoto é de grande interesse entender a interação da radiação com o dossel da vegetação, em duas regiões do espectro eletromagnético: (a) na faixa que vai de 400 a $2500 \mathrm{~nm}$, correspondente às regiões do visível, do infravermelho próximo e médio e; (b) na faixa que vai de 8000 a $14000 \mathrm{~nm}$ que corresponde à região do infravermelho termal (distante). Nesta região, a energia proveniente dos alvos é devida a temperatura, portanto, trata-se de energia emitida e não refletida, como acontece na faixa discutida no item (a); apesar de serem estas duas regiões do espectro eletromagnético utilizadas no sensoriamento remoto, muita ênfase tem sido dada ao entendimento da interação da radiação com dossel de vegetação, na faixa que vai de 400 a $2500 \mathrm{~nm}$, uma vez que a radiação solar incidente ocorre predominantemente nesta faixa. 


\subsection{Fontes de radiação eletromagnética}

A maior parte da radiação disponível nas bandas do ultra-violeta, visível e infravermelho, tem origem térmica, isto é, resulta da emissão de energia radiante por corpos aquecidos. Qualquer objeto cuja temperatura seja maior que zero absoluto, emite um espectro contínuo de radiação eletromagnética que depende da temperatura do objeto; na realidade o objeto reemite a mesma energia que é capaz de absorver do ambiente e a eficiência desse processo, depende das suas propriedades. Um corpo capaz de absorver toda a energia incidente sobre ele e reemitíla na forma de espectro contínuo é denominado de corpo negro (Steffen, 1996a).

Novo (1995), afirma que o sol é a principal fonte de energia eletromagnética disponível para o sensoriamento remoto da superficie terrestre, em geral admite-se que a emissão de energia do sol assemelha-se à de um corpo negro com temperatura equivalente a $5900^{\circ} \mathrm{K}$. Segundo o autor e tendo como base a Figura 3, a qual representa graficamente a energia radiante do sol que incide sobre a terra para cada comprimento de onda, o máximo de energia solar disponível na superfície terrestre encontra-se na faixa de $400 \mathrm{~nm}$ a $700 \mathrm{~nm}$ que é conhecida como região visível do espectro eletromagnético; existem ainda regiões do espectro eletromagnético para as quais a atmosfera é opaca, ou seja, não permite a passagem das radiação eletromagnética. Conclui ainda que as interações da radiação eletromagnética com os principais componentes atmosféricos responsáveis pela absorção solar $\left(\mathrm{O}_{3}, \mathrm{O}_{2}, \mathrm{H}_{2} \mathrm{O}\right.$ e $\left.\mathrm{CO}_{2}\right)$, interferem na qualidade e na quantidade de energia solar disponível para o sensoriamento remoto dos recursos terrestres, sendo assim, outras fontes de radiação são utilizadas para este fỉm, como a própria terra. Assim, pela comparação do espectro de emissão da terra com o espectro de emissão do sol, afirma que quanto maior a temperatura de um corpo, maior a quantidade de energia por ele emitida e menor o comprimento de onda de emissão máxima.

Gardner et al. (1985), citam que o fluxo radiante que chega à superficie terrestre possui um espectro contínuo entre $300 \mathrm{~nm}$ a $4000 \mathrm{~nm}$. Do total dessa energia, $44 \%$ a $50 \%$ concentra-se na faixa do visível que vai de 400 a $700 \mathrm{~nm}$, a qual é perceptível pelo olho 
humano e, por coincidência, é a radiação absorvida pelas plantas para realizar a fotossintese. Pelo motivo de ser utilizada na fotossíntese, ela recebe a denominação de radiação fotossinteticamente ativa - PAR.

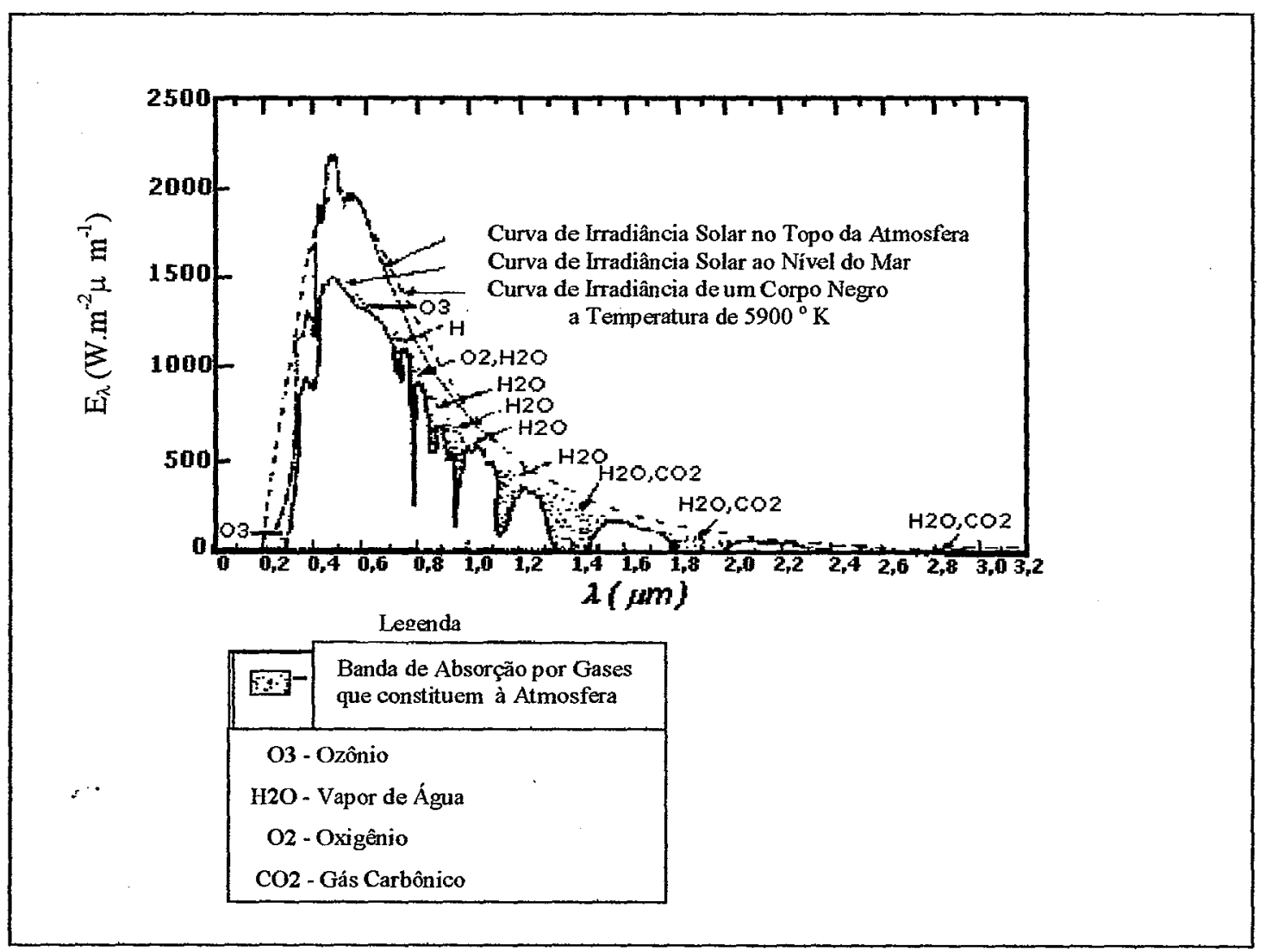

Figura 3 - Curva de irradiância solar. Fonte: Slater (1980), citado por Novo (1995).

\subsection{Radiometria}

Sabe-se que a radiometria é a mensuração da energia eletromagnética refletida ou emitida por um objeto em um determinado intervalo de comprimento de onda. Os sistemas que medem essas quantidades de energia são denominados radiômetros, os quais são capazes de mensurar alguns parâmetros na radiometria; estes recebem o nome de grandezas radiométricas. 
Steffen \& Moraes (1993), citam que das grandezas radiométricas, a mais fundamental é a Energia radiante (Q), cuja unidade é o Joule (J) e é a partir dela que todas as outras grandezas são calculadas, tais como: Fluxo radiante $(\phi)$, Irradiância $(E)$, Radiância (L), Exitância (M) e Intensidade radiante (I).

Moreira (1997), define as três mais usadas grandezas radiométricas neste tipo de levantamento, como sendo:

a)- Fluxo radiante $(\phi)$ : a quantidade de energia radiante que passa por uma posição do espaço na unidade de tempo, dada em Joule/segundo (J/s) ou Watt (W);

b)- Irradiância (E): razão entre o fluxo radiante que incide numa amostra da superfície e a sua respectiva área $\left(\mathrm{W} / \mathrm{m}^{2}\right)$;

c)- Radiância (L): é a razão entre o fluxo radiante refletido (ou emitido) por unidade de área projetada e por unidade de ângulo sólido na direção considerada (W/ $\mathrm{m}^{2}$.sr). A radiância é uma grandeza direcional e corresponde à sensação visual de brilho da amostra de superfície, e se ela não varia com a direção, a superfície é um difusor perfeito (lambertiana)

Cita ainda o autor que aproveitando os conceitos de grandeza radiométrica, pode-se determinar também uma grandeza adimensional denominada reflectância, que é a razão entre o fluxo de energia incidente sobre uma superficie e o fluxo de energia refletido pela superficie, apresentando valores compreendidos entre 0 a 1 . Como a reflectância não existe como grandeza física (é uma razão entre a radiância e a irradiância), não pode ser medida diretamente, assim sendo é expressa em termos de radiância e podendo assim ser medida pelo radiômetro

Segundo Steffen (1996b), para se medir na prática a reflectância, utiliza-se do conceito de superficie perfeitamente difusa; superficie esta com reflectância unitária e que reflete uma radiância constante independente do ângulo de visada. Utiliza-se para simular tal superficie uma placa referência recoberta com Sulfato de Bário $\left(\mathrm{BaSO}_{4}\right)$ ou Óxido de Magnésio ( $\mathrm{MgO}$ ) e calibrada com relação a um determinado padrão de laboratório de reflectância conhecida. Assim sendo, utiliza-se um radiômetro e mede-se a radiância dessa superfície padrão e em seguida a de um alvo em estudo, calculando-se 
assim o Fator de Reflectância (Bidirecional), que é a razão entre a radiância refletida do alvo em estudo e a radiância refletida da placa de referência (suposta superfície completamente difusora), nas mesmas condições de iluminação.

\subsection{Comportamento espectral do dossel vegetativo}

Segundo Moreira (1997), o modo como a planta ou uma comunidade de plantas é vista, seja pelo olho humano ou através de um sensor multiespectral, depende fundamentalmente da interação da energia eletromagnética com a planta ou com a comunidade de plantas. A parte da planta envolvida nesta interação é referida por dossel, que é constituído de folhas; caules; espigas; flores; etc; porém, as folhas são as que tềm maior importância na interação do fluxo radiante com a vegetação, tendo em vista que são nelas que se realiza quase toda fotossíntese, responsável pela produção de carbohidratos. Para o autor e devido à necessidade da folha captar o máximo de radiação solar, observa-se uma predominância da área foliar quando comparada à área de outros órgãos da planta; desta forma, normalmente a área dos outros órgãos, expostos à radiação solar, é desprezada pelo sensoriamento remoto.

Formaggio (1989), define dossel vegetativo como sendo todos os componentes da vegetação que estão situados acima da superficie do solo. Assim, as propriedades de reflectância de folhas individuais são evidentemente, fundamentais para o perfeito entendimento da refletividade de uma planta inteira ou de um dossel vegetal. Contudo, não se pode extrapolar diretamente sem modificações, os dados espectrais de uma folha individual para um dossel pois, existem diferenças qualitativas e quantitativas nos dois tipos de espectros.

Uma folha típica é constituída de três tecidos básicos que são a epiderme, mesófilo fotossintético e tecido vascular (Figura 4). A folha é então coberta por uma camada de células protetoras epidérmicas e abaixo desta se encontra o mesófilo, o qual freqüentemente é subdividido em uma camada ou em camadas de células paliçádicas alongadas, arranjadas perpendicularmente à superficie da folha, formando o parênquima, 
onde estão a seiva e o protoplasma. Esparsos através do mesófilo estão os espaços intercelulares cheios de ar, os quais se abrem para fora através dos estômatos ( Cardoso \& Ponzoni, 1996).

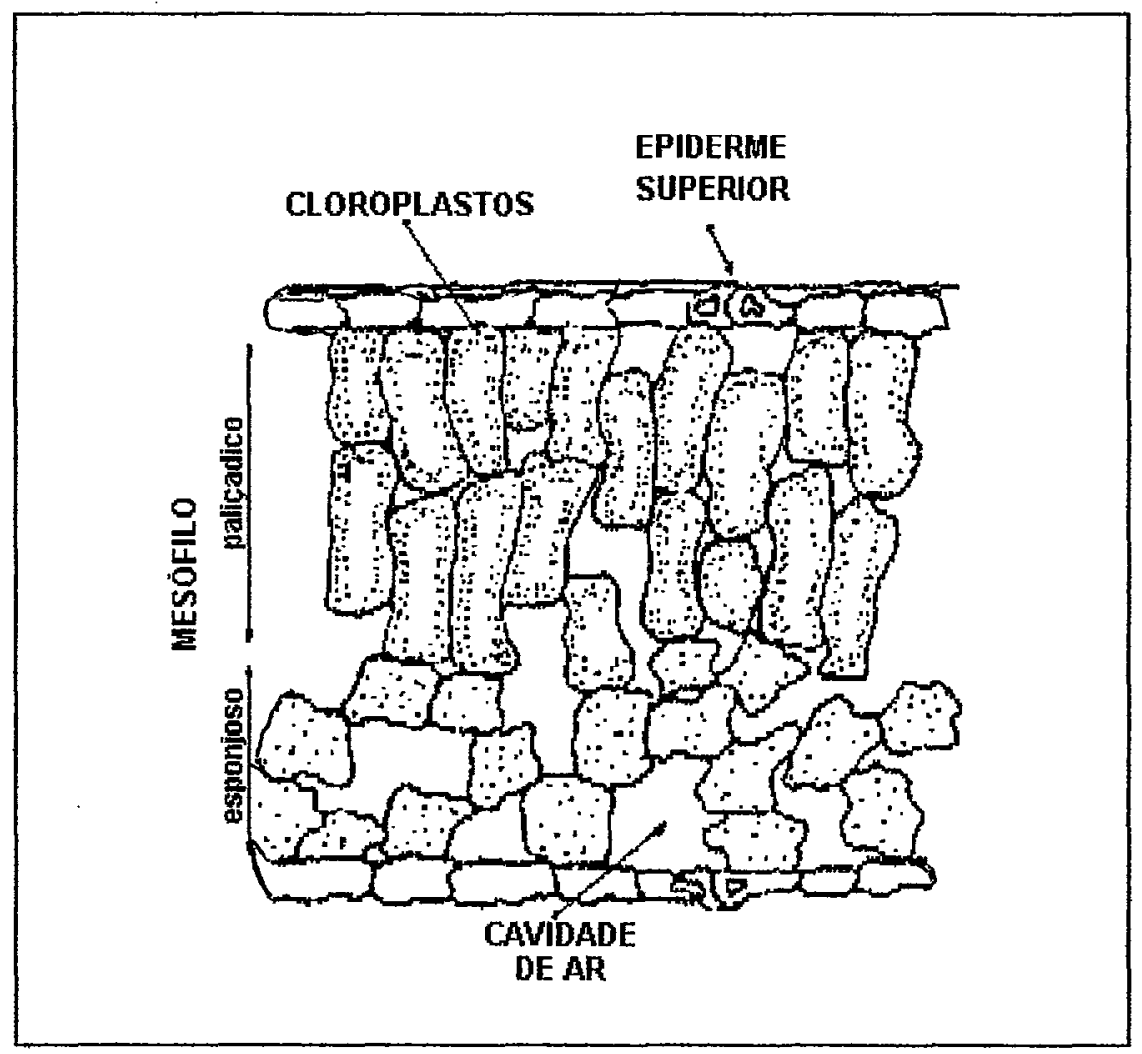

Figura 4 - Estrutura morfológica de uma folha verde normal.

Fonte: Bunnik (1978), citado por Formaggio (1989)

Em relação as possíveis trajetórias da radiação incidente numa folha, Moraes (1996), frisa que uma pequena quantidade de radiação é refletida das células da camada superficial; a maior parte é transmitida para o mesófilo esponjoso, onde os raios incidem freqüentemente nas paredes celulares, sendo refletidos se os ângulos de incidência forem suficientemente grandes; esta reflexão múltipla é essencialmente aleatória, no qual os componentes do fluxo mudam de direção dentro da folha. Dado o grande número de paredes celulares na folha, alguns componentes são refletidos de volta para o hemisfério de incidência, enquanto outros são transmitidos através da folha. 
Analisando o comportamento espectral de culturas agrícolas de ciclo curto, Formaggio (1989), observa que no caso dessas culturas, há uma variação da quantidade de material vegetal contido no dossel da plantação durante o ciclo. Assim, tal qual é mostrado na Figura 5, a extensão do ciclo de uma cultura pode ser subdividida em três fases fenologicamente distintas: (a) primeira fase: domínio do solo nas interações com a radiação eletromagnética, indo do plantio, a germinação e o desenvolvimento inicial em que a cultura não recobre totalmente a superfície do solo; (b) segunda fase: ocorre o domínio da cobertura verde nas interações da cultura com a radiação eletromagnética, aqui já se "fechou" o dossel da cultura e no final desta fase é que ocorre e o florescimento e a formação de grãos; (c) terceira fase: nesta última fase do ciclo fenológico/espectral de uma cultura agrícola, se destaca a maturação e a senescência, aqui ocorre o secamento e a queda das folhas, voltando-se a expor grande percentagem do solo e, assim, ocorrendo o domínio conjugado da vegetação seca e do solo exposto. Ainda para $o$ autor, entre os fatores que influenciam a resposta espectral dos dosséis vegetais de culturas agrícolas estão o solo, a estrutura dos dosséis (densidade de plantio e arquitetura das plantas) e aspectos de geometria de iluminação e de visada de cena.

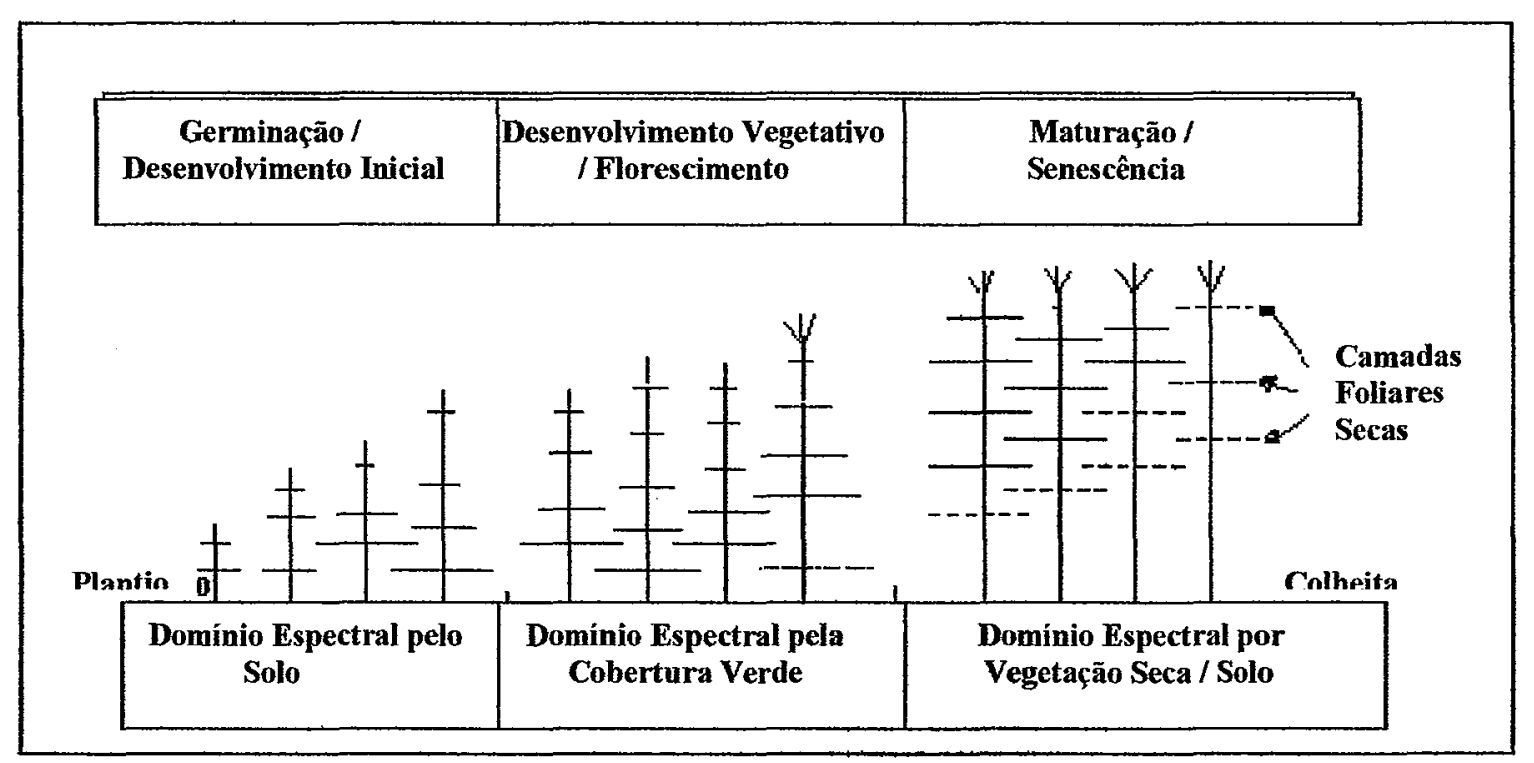

Figura 5 - Ilustração esquemática das três grandes fases do ciclo fenológico de uma cultura agrícola, quanto aos principais componentes do sistema a influenciar a resposta espectral dos dosséis. Fonte: Formaggio (1989). 
O comportamento espectral da vegetação ou dossel vegetativo, se manifesta de forma distinta em três regiões espectrais, são as regiões do visível, do infravermelho próximo e do infravermelho médio. A Figura 6 dada abaixo nos mostra as principais características da resposta espectral das folhas verdes nessas três regiões.

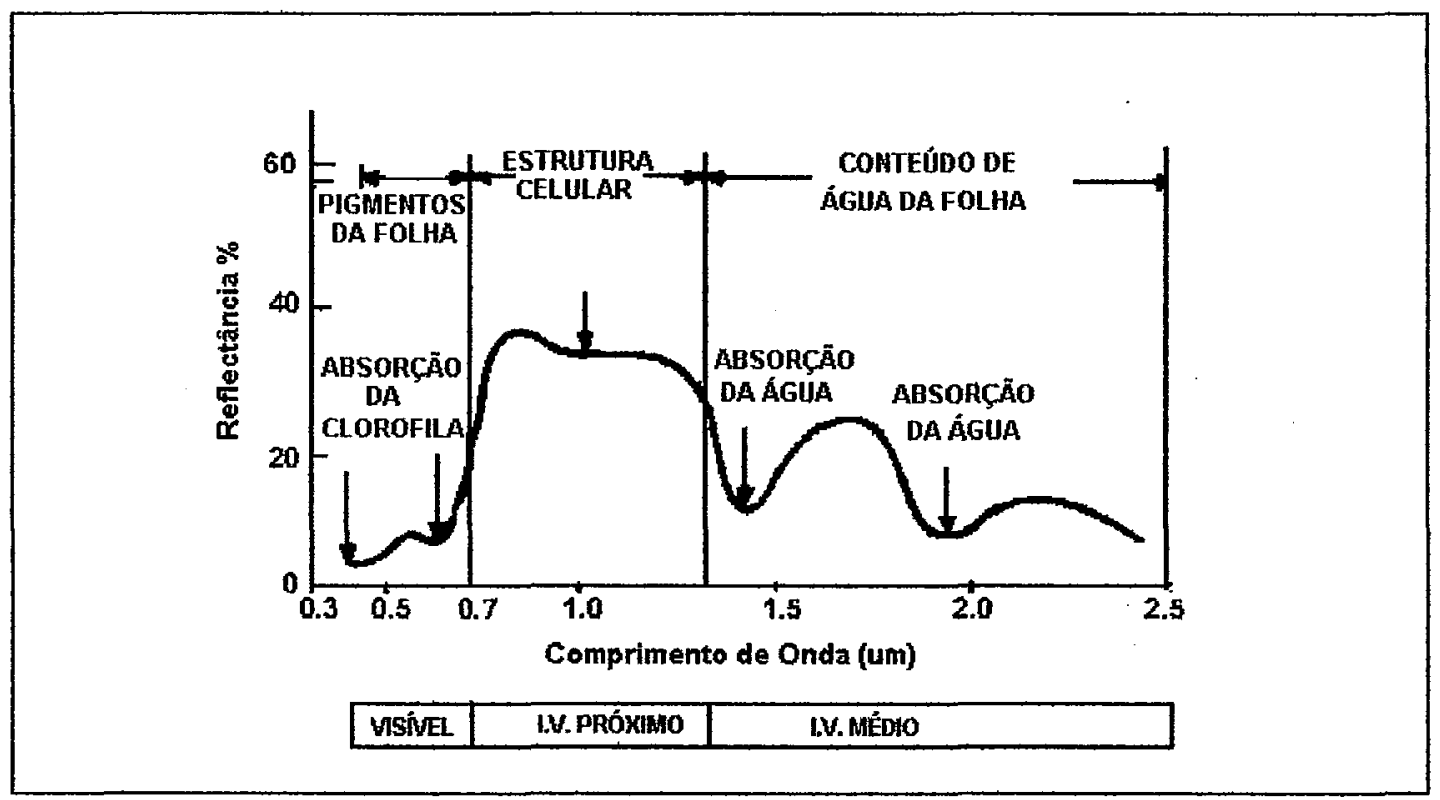

Figura 6 - Curva média da vegetação fotossinteticamente ativa. Fonte: Novo (1995).

\subsubsection{Região do visível}

A região do visivel do espectro eletromagnético situa-se na faixa espectral entre $400 \mathrm{~nm}$ a $700 \mathrm{~nm}$ e pode ser percebida pelo sistema visual humano. Esta radiação é também aquela em que os pigmentos das folhas dos vegetais absorvem para realizar a fotossíntese e para serem utilizadas em outros processos bioquímicos da planta. Essa faixa da radiação solar é denominada de radiação fotossinteticamente ativa e, no inglês, é denominada de "Photosynthetically Active Radiation" (PAR), sendo que a maior parte da PAR que pode incidir sobre o dossel vegetativo é absorvida no mesófilo das folhas pelos pigmentos fotossintetizantes existentes nos cloroplastos, predominantemente as clorofilas a e $\underline{b}$, embora, os carotenóides, as xantofilas e antocianinas contribuam em menor intensidade nessa absorção (Moreira, 1997). 
Para Moraes (1996), na região do visível os pigmentos existentes nas folhas dominam a assinatura espectral. Esses pigmentos, geralmente encontrados nos cloroplastos são: clorofila (65\%), carotenos (6\%) e xantofilas (29\%), sendo que esses valores percentuais variam de espécie para espécie.

Silva (1995), comenta que a faixa do visível $(0,40 \mu \mathrm{m}$ a $0,70 \mu \mathrm{m})$, compõem-se das cores azul, verde e vermelho e que essa faixa se caracteriza pela baixa reflectância e alta absortância atribuídas à presença de pigmentos carotenóides e xantofilicos; verificase, porém, aumentos de reflectância nas regiões medianas do visível $(0,55 \mu \mathrm{m}) \mathrm{em}$ decorrência da menor absorção de radiação, refletindo o verde.

De acordo com Novo (1995), até $0,70 \mu \mathrm{m}$, a reflectância é baixa (< que 20\%), dominando a absorção da radiação incidente pelos pigmentos das plantas em $0,48 \mu \mathrm{m}$ (carotenóides) e em 0,62 $\mu \mathrm{m}$ (clorofila). Em 0,56 $\mu \mathrm{m}$, há um pequeno aumento do coeficiente de reflectância, não atingindo porém níveis superiores a $10 \%$; ẽ a reflectância responsável pela percepção da cor verde da vegetação.

\subsubsection{Região do infravermelho próximo}

Didaticamente, esta região situa-se na faixa espectral entre 700 a $1300 \mathrm{~nm}$. Nesta região, a radiação incidente ao interagir com uma vegetação sadia apresenta uma maior percentagem de energia refletida e transmitida e uma menor percentagem de radiação absorvida, quando comparada com a região do visíve1.

Segundo Formaggio (1989), nessa região as folhas verdes sadias apresentam altos valores de reflectância (45-50\%), alta transmitância (45-50\%) e baixa absortância (menor que 5\%). Essa elevada reflexão de energia na região do infravermelho próximo é atribuída à estrutura interna das folhas.

Silva (1995), afirma que na faixa do infravermelho próximo, a maior porcentagem de energia refletida e transmitida deve-se a estrutura interna da folha; isto é, as radiações ao incidirem na estrutura foliar, são espalhadas pela cutícula e epiderme 
para as células do mesófilo e cavidades de ar, onde sofrem novo espalhamento seguidos de reflexões e refrações múltiplas. Como as estruturas internas das folhas variam de uma espécie vegetal para outra, para o autor, isso explica a razão da maior reflectância normalmente observada no infravermelho que na região do visível, sendo ainda esta faixa de comprimento de onda a mais indicada para identificação de culturas.

\subsubsection{Região do infravermelho médio}

A região do infravermelho médio do espectro eletromagnético situa-se na faixa espectral entre $1300 \mathrm{~nm}$ a $3000 \mathrm{~nm}$.

Nesta região, em folhas túrgidas, a absorção da radiação pela água é muito acentuada na faixa espectral situada entre $1300 \mathrm{~nm}$ a $2500 \mathrm{~nm}$, consequentemente iremos observar uma baixa reflectância. Assim sendo, denomina-se este efeito de primário, porque o decréscimo na reflectância se deve exclusivamente ao conteúdo de água nas folhas e também pela propriedade absortiva da água (Moreira, 1997).

Bauer et al. (1980), mostram que nesta região, a interação da radiaçã̀o eletromagnética com a vegetação sadia é caracterizada principalmente pelas fortes bandas de absorção pela água da radiação incidente. Assim sendo, nesta faixa de comprimento de onda, a água absorve mais ainda a radiação solar nos comprimentos próximos a $1400 \mathrm{~nm}$ e a $1900 \mathrm{~nm}$ e possui um pico de reflectância máximo em 1450nm e $2200 \mathrm{~nm}$. Portanto, as regiões existentes entre essas bandas de absorção são fortemente influenciadas pelo conteúdo de umidade das folhas. Concluem ainda os autores que, nesta região, a reflectância foliar é inversamente relacionada com a quantidade total de água presente nas folhas, isto é, em folhas túrgidas iremos observar uma baixa reflectância e uma alta absorção.

A relação inversa entre a reflectância de uma folha e a absorção de água na região do infravermelho médio é mostrada através de um exemplo ilustrativo (Figura 7 ). 


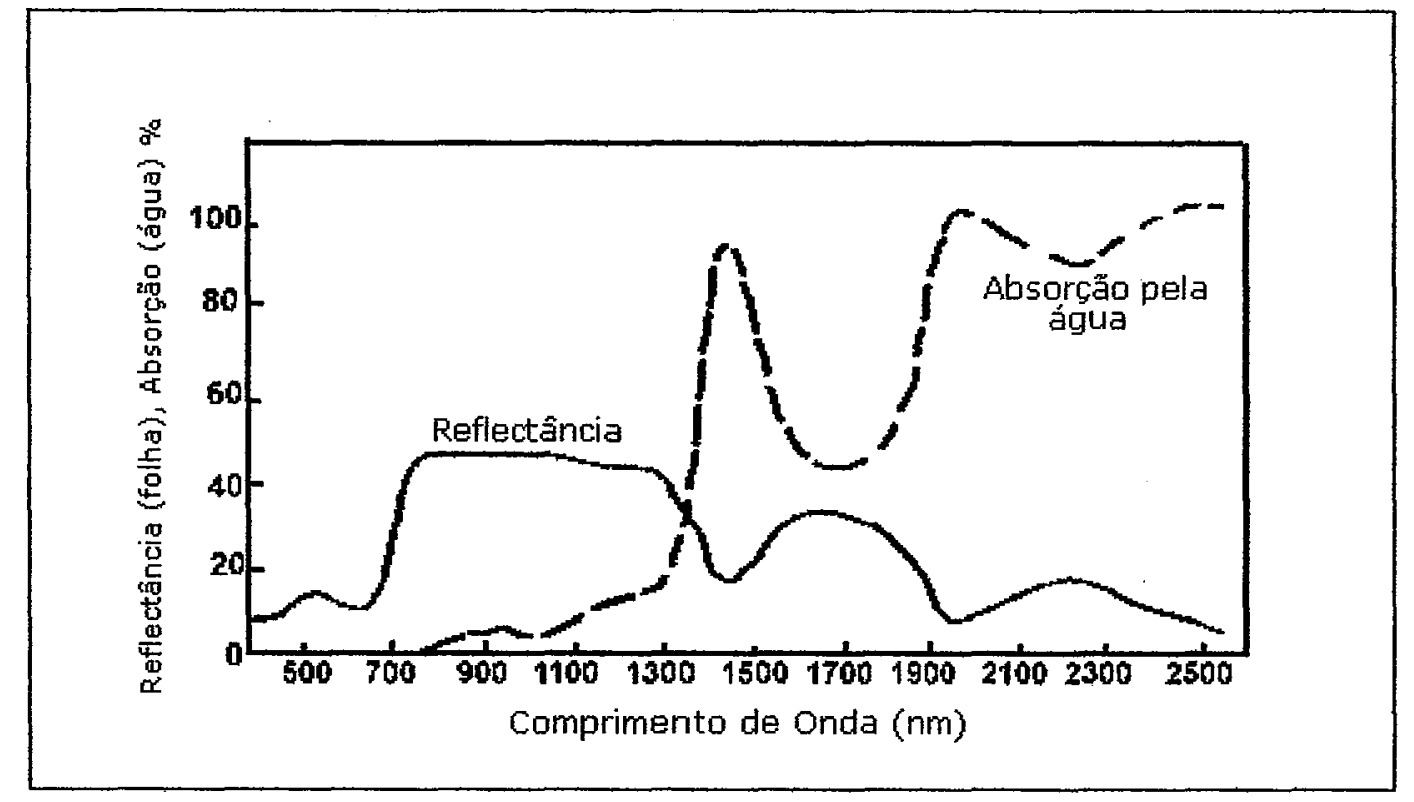

Figura 7 - Relação inversa entre a reflectância de uma folha e a absorção de água.

Fonte: Moreira (1997).

\subsubsection{Fatores que afetam as propriedades ópticas da folha}

Vários fatores podem afetar as propriedades ópticas da folha. Entre esses podem ser citados: a estrutura anatômica das folhas, a idade das folhas, deficiência de nutrientes na planta, ocorrência de pragas e doenças ou ainda o fator turgidez das folhas. Esses fatores são comentados a seguir:

(a) Estrutura anatômica da folha: a reflectância no infravermelho próximo é geralmente afetada pela estrutura anatômica das folhas e depende dos estratos celulares, do tamanho das células e da expessura do mesófilo esponjoso; assim, as folhas de dicotiledôneas possuem reflectância maior do que as de monocotiledôneas para uma mesma espessura, porque as primeiras têm um mesófilo esponjoso mais desenvolvido ( Guyot , 1990).

(b) Idade das folhas: as propriedades ópticas de uma folha mudam de acordo com a sua fase de desenvolvimento. Assim sendo, na maturação, ocorre um decréscimo da reflectância na região do visível e um aumento na região do infravermelho próximo, 
devido a existência de um maior número de espaços aéreos intercelulares no mesófilo das folhas maduras. No início da senescência, e em razão da degradação das clorofilas, ocorre uma menor absorção da radiação solar e, conseqüente aumento da reflectância na região do visível; posteriormente, com o avanço gradativo da senescência, observa-se a degradação dos carotenos e morte das células. Nessa fase, ocorre um aumento dos espaços aéreos intercelulares das folhas, e conseqüente aumento da reflectância no infravermelho próximo (Moreira, 1997), como é mostrado na Figura 8.

(c) Nutrientes: sabe-se que a deficiência de nutrientes no vegetal, afeta de forma bastante significativa as propriedades ópticas das folhas. A deficiência de nitrogênio provoca uma clorose a qual é responsável pelo aumento da reflectância na região do visível, devido ao decréscimo do conteúdo de clorofila e um decréscimo da reflectância na região do infravermelho próximo (Thomas \& Oerther, 1972). Trabalhos existentes mostram ainda a influência da deficiência de outros nutrientes como o fósforo, potássio, enxofre, magnésio e cálcio, na redução da concentração de clorofila da folha e conseqüente redução da absortância e aumento da reflectância na faixa do visível.

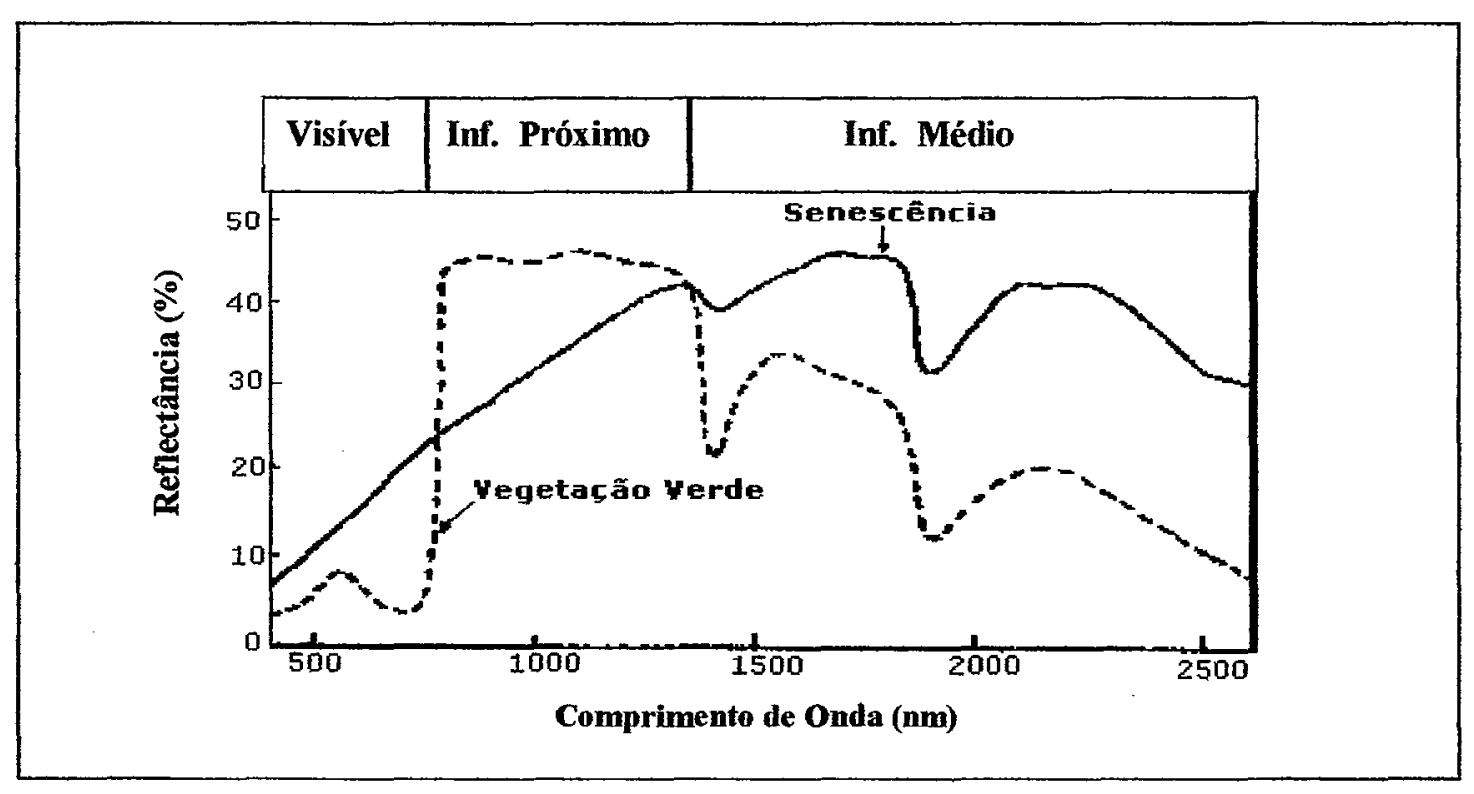

Figura 8 - Curvas de reflectância espectral de folhas de plantas obtidas durante a fase de crescimento vegetativo e durante a senescência. Fonte: Guyot (1990), citado por Moreira (1997). 
(d) Doenças e pragas: alguns fungos e insetos podem influenciar a assinatura espectral de folhas infestadas por estes. Em relação aos fungos, Moraes (1996), cita que Colwell (1956) e Kumar (1972), verificaram que a reflectância nas folhas doentes era maior do que nas sadias na região do visível, o que provavelmente poderia ser explicado pela perda de clorofila. Contudo, ela era menor na região do infravermelho próximo, o que também pode ser explicado pela invasão das hifas nos espaços intercelulares.

(e) Conteúdo de água na folha: na região do infravermelho próximo a absorção da água é geralmente baixa e a assinatura espectral é quase constante. Gates (1980), afirma que a assinatura espectral de folhas nessa região é o resultado da interação entre a energia incidente e o mesófilo, assim, fatores externos a folha como disponibilidade de água, podem causar alterações na relação água-ar no mesófilo, podendo alterar a reflectância de uma folha nesta região.

\subsection{Radiometria de campo}

Define-se a radiometria ou espectrorradiometria de campo, como uma técnica de sensoriamento remoto empregada para medir a radiação solar refletida de objetos na superfície terrestre, em determinadas faixas ou bandas espectrais. Por utilizar a radiação solar como fonte de energia, ela é dita passiva (Deering, 1980).

Jackson \& Huete (1991), citam que desde meados dos anos 70, pesquisadores se utilizavam de pequenos radiômetros, leves e portáteis, os quais podiam ser carregados por uma pessoa ou montados em veículos, com o objetivo principal de coletar dados espectrais que pudessem auxiliar na interpretação de imagens orbitais de satélites.

O emprego de dados espectrais, coletados por sensores colocados em satélites orbitais, nos estudos relacionado à agricultura, depende muito do conhecimento das interações da radiação eletromagnética com os dosséis agrícolas. Uma das maneiras de estudar estas interações da radiação eletromagnética com dosséis agrícolas, é através de pesquisas básicas realizadas ao nível do solo; dentro desse objetivo a radiometria de campo é bastante utilizada (Milton, 1987). 
Para Formaggio (1989), as técnicas que usam a radiação refletida (nas regiões espectrais do visivel e do infravermelho) têm sido mais úteis para se estimar propriedades das plantas, tais como a fitomassa, produção de grãos e o índice de área foliar; propriedades que por sua vez podem servir como dados de entrada para modelos de crescimento de plantas e para modelos de evapotranspiração.

Segundo Novo (1995), os equipamentos empregados para medir a radiação solar refletida dos objetos são classificados em duas categorias: (a)- Radiômetros de banda: produzem informações sobre a resposta do alvo em faixas largas do espectro; há radiômetros como o Exotech, que opera em 4 faixas espectrais $(0,5 \mu \mathrm{m}-0,6 \mu \mathrm{m} ; 0,6 \mu \mathrm{m}$ $0,7 \mu \mathrm{m} ; 0,7 \mu \mathrm{m}-0,8 \mu \mathrm{m} ; 0,8 \mu \mathrm{m}-1,1 \mu \mathrm{m})$. Estas faixas ou bandas espectrais indicam que o radiômetro integrará toda a energia proveniente do alvo em cada banda. Assim, se tivermos um alvo natural com baixa reflectância em $0,5 \mu \mathrm{m}$ e elevada reflectância em $0,6 \mu \mathrm{m}$, o sinal detectado pelo radiômetro corresponderá grosseiramente a uma média daquelas respostas e (b)- Espectrorradiômetros: os quais distinguem-se dos radiômetros de banda, porque operam em faixas espectrais estreitas. $O$ sistema de dispersão usado por estes, decompõe a radiação incidente em diferentes comprimentos de onda, de tal forma que se possa medir a resposta do alvo quase de maneira contínua ao longo do espectro eletromagnético. Afirma ainda o autor que, os espectrorradiômetros permitem a obtenção de curvas espectrais com maior número de informações que aquelas produzidas pelos radiômetros.

De acordo com Steffen (1996a), os espectros do fator de reflectância dos objetos de interesse do sensoriamento remoto, devem ser de preferência, medidos em condições de campo onde ficam preservadas as suas propriedades, como também, as condições de iluminação natural à que estão submetidos quando imageados pelos sensores remotos. A definição de um sistema para a medição radiométrica de campo deve considerar prioritariamente as características dos espectros que se pretende obter, principalmente: resolução e intervalo espectrais das medidas, o campo de visada necessário para a amostragem e a acessibilidade das amostras. Para o trabalho de campo, é desejável a utilização de equipamentos radiométricos com as seguintes características: 
(a) peso e volume reduzidos; (b) unidade detectora separada da unidade controladora; (c) suprimento de energia por bateria recarregável; (d) sistema de armazenamento de dados e (e) pequeno tempo de aquisição e comunicação com computador. Segundo ainda o autor, atualmente existem vários sistemas de medição espectral disponíveis comercialmente que satisfazem ao menos parcialmente esses requisitos, e entre esses cita o SPECTRON SE-590.

Epiphanio (1989), menciona algumas das características essenciais das medidas radiométricas medidas no campo e suas vantagens: (a) os dados são obtidos próximo à superficie com influência de ordem mínima da atmosfera; (b) os espectrorradiômetros são sensores que geralmente possuem um número maior de bandas espectrais (alta resolução espectral) do que os sensores a bordo de satélite ou de aeronave; (c) devido à proximidade do alvo-sensor, pode-se controlar melhor as relações entre as medidas espectrais e os parâmetros biofísicos.

\subsection{0. Índices de vegetação}

Um índice de vegetação nada mais é do que a combinação (razão ou diferença) da reflectância espectral da vegetação obtida em duas faixas espectrais especificas relacionadas com as características particulares da vegetação. Tais índices apoiam-se no fato de que com o aumento da quantidade de fitomassa, há um aumento na reflectância do infravermelho próximo e um decréscimo na reflexão do visível (Moreira, 1997).

A fim de relacionar parâmetros agronômicos com indicadores espectrais das condições vegetativas de culturas, ao invés de se usar bandas individuais simplesmente, a abordagem mais utilizada tem sido os índices de vegetação (Formaggio, 1989).

Pearson \& Miller (1972), foram os primeiros a notar a existência de uma correlação linear negativa entre $o$ fator de reflectância e a vegetação verde no comprimento de onda de $680 \mathrm{~nm}$ (visível) e uma correlação linear positiva em $780 \mathrm{~nm}$ (infravermelho próximo). 
A partir desse momento, os pesquisadores começaram a desenvolver vários índices de vegetação, com o intuito de caracterizar alguns dos parâmetros biofísicos da vegetação.

Jackson et al. (1980) e citado por Formaggio (1989), afirmam que um índice de vegetação é obtido através da razão, diferenciação ou outro tipo de combinação ou transformação de dados espectrais, a fim de representar características de dosséis de plantas, tais como o índice de área foliar, a fitomassa, o peso da matéria verde, o peso da matéria seca, a porcentagem de cobertura do terreno por vegetação e outros. $O$ seu objetivo é também diferenciar vegetação de solo e fornecer um valor numérico que possa ser relacionado com vários parâmetros da planta.

Segundo Moreira (1997), o emprego de índices de vegetação para caracterizar e quantificar um determinado parâmetro biofisico de culturas agrícolas, tem duas grandes vantagens: (a) permite reduzir a dimensão das informações multiespectrais por meio de um simples número, além de minimizar o impacto das condições de iluminação e visada; e (b) fornece um número altamente correlacionado com parâmetros agronômicos.

A maioria dos índices de vegetação são obtidos de medidas do fator de reflectância sobre dosséis de vegetação, nas faixas espectrais do vermelho $\mathrm{e}$ infravermelho próximo ( Huete \& Jackson, 1988). Para Baret et al. (1989), existem duas razões básicas para o uso dessas faixas espectrais: (a) estão presentes em 'quase todos os satélites de sensoriamento remoto e (b) contém mais de $90 \%$ da informação espectral da vegetação.

De acordo com Choudhury (1987), os dois índices de vegetação mais comumente usados para a estimativa da APAR são: razão simples (RS) e o índice de vegetação diferença normalizada (NDVI), os quais são definidos pelas expressões dadas a seguir.

$$
\mathrm{RS}=\frac{\mathrm{IVP}}{\mathrm{V}}
$$

$\underline{\mathrm{e}}$ 


$$
\mathrm{NDVI}=\frac{(\mathrm{IVP}-\mathrm{V})}{(\mathrm{IVP}+\mathrm{V})}
$$

em que: IVP é o fator de reflectância medida na faixa espectral do infravermelho próximo, V é o fator de reflectância medida na faixa espectral do vermelho.

Apesar de que sobre o ponto de vista matemático, esses dois índices apresentem equivalências funcionais, entretanto, o NDVI é mais sensível a vegetação esparsa do que o RS (Jackson \&. Huete, 1991).

Vários pesquisadores utilizaram o índice NDVI em seus trabalhos e obtiveram respostas satisfatórias para os objetivos traçados. Batista et al. (1988), visando relacionar a resposta espectral de duas variedades de soja (Santa Maria e IAC-9) com parâmetros agronômicos (altura das plantas, rendimento de grãos, estimativa de percentagem de cobertura do solo e medida de biomassa verde), realizaram sobre cada parcela, uma série de medidas radiométricas ao longo do ciclo da cultura e utilizando o radiômetro portátil Abe Sekkei. Os resultados mostraram que a resposta espectral da soja, transformada em índice vegetativo (razão entre a banda do infravermelho próximo- $850 \mathrm{~nm}$, pela banda do vermelho $-650 \mathrm{~nm}$ ) foi significativamente correlacionada com todos os parâmetros agronômicos analisados, sendo que o índice vegetativo explicou próximo a $80 \%$ da variação da biomassa verde.

Rudorff et al. (1997), realizaram um experimento de campo para verificar o efeito do déficit hídrico (reposição de $100 \%, 50 \%$ e $25 \%$ da água evapotranspirada) e da adubação nitrogenada em dois cultivares de trigo (IAC-24 e IAC-287); como parte deste experimento foram realizadas medidas de radiometria de campo, com o SPECTRON

- SE-590. Os valores de reflectância correspondentes as bandas 3 e 4 do sensor TM foram utilizadas para obter os valores do índice vegetativo da diferença normalizada (NDVI). Concluíram os autores que as interações para os valores de NDVI foram consideradas significativas para irrigação versus cultivar na fase de floração, indicando que o déficit hídrico teve efeito mais pronunciado nos valores do NDVI para o cultivar IAC-287. 
Moreira (1997), ao empregar o NDVI para detectar os efeitos do estresse de água na cultura do trigo, concluiu que esse índice foi mais consistente do que a análise das informações espectrais de bandas individuais; através do NDVI foi possível também perceber as diferenças nos valores do FR tanto na banda $\mathrm{TM}_{3}$, quanto na banda $\mathrm{TM}_{4} \mathrm{e}$ ocorridas em datas diferentes.

É sempre importante frisar que o NDVI é calculado com a intenção de ser utilizado em modelos matemáticos que possam estimar uma fração da PAR que é absorvida pelo dossel da cultura. O uso do valor do NDVI, sem a presença desses modelos, não apresenta grande significado. No presente trabalho, os valores de NDVI foram utilizados para estimar a radiação fotossinteticamente ativa absorvida acumulada $\left(\mathrm{APAR}_{\mathrm{ac}}\right)$, e conseqüentemente permitir o cálculo da eficiência do uso da radiação pela cultura do feijão irrigada para a produção de grãos.

\subsection{Radiação fotossinteticamente ativa absorvida pelo dossel vegetativo}

Sabe-se que entre os fatores ambientais que influenciam o crescimento das plantas terrestres, a radiação solar tem um relevante destaque por ser a única fonte de energia para o processo fotossintético (Asrar et al., 1984).

A quantidade de radiação solar, potencialmente disponível para os processos fotossintéticos e para o consumo da planta, em termos fotoquímicos é denominada de radiação fotossinteticamente ativa (PAR) e corresponde à radiação solar na faixa de comprimento de onda entre $400 \mathrm{~nm}$ e $700 \mathrm{~nm}$. A soma algébrica da PAR, que é absorvida pelo dossel da vegetação, é denominada de radiação fotossinteticamente ativa absorvida (APAR). A quantidade de radiação fotossinteticamente ativa interceptada pelo dossel é denominada de PAR (Moreira, 1997).

Várias pesquisas têm demonstrado ainda que a produção de matéria seca, de muitas culturas agrícolas, é proporcional a radiação fotossinteticamente ativa (PAR) absorvida pelos elementos fotossintetizantes do dossel vegetativo (Steven et al., 1983; Prince, 1991; Moreira,1997). 
Outras pesquisas mostram ainda que em relação a APAR, nota-se que em plantas sadias e adequadamente supridas com água e nutrientes, existe uma relação linear positiva entre a produção de fitomassa e/ou grãos e a quantidade da PAR absorvida pelo dossel (Gallo et al., 1985; Asrar, 1989; Prince, 1991; entre outros).

Entretanto, a quantificação da APAR, através de técnicas de sensoriamento remoto, não pode ser feita de forma direta, porque não existem equipamentos para medila. A alternativa empregada é quantificar todos os outros termos da equação do balanço de energia e, a partir desses valores, estima-se a parte absorvida (Moreira, 1997). Dessa forma, são usados os índices de vegetação na estimativa da APAR, índices estes obtidos de medidas do fator de reflectância nas bandas espectrais do vermelho e do infravermelho próximo (Asrar et al., 1984; Choudhury, 1987; Baret et al., 1989).

Vários modelos matemáticos tem sido empregados com sucesso na estimativa da APAR para as culturas. Entre as pesquisas desenvolvidas nesse sentido, pode-se citar as de Steven et al. (1983); Asrar et al. (1984); Choudhury (1987) e Rudorff et al. (1997).

Segundo ainda Baret et al. (1989), a avaliação da fitomassa através da APAR é uma informação mais realística do que o uso do índice de área foliar (IAF), porque esta energia é transformada em matéria seca.

\subsection{Eficiência de uso da radiação}

Entende-se por eficiência do uso da radiação ou eficiência fotoquímica $(\varepsilon)$, a razão da matéria seca produzida por unidade de energia PAR absorvida e usada na sua produção; ou seja, a eficiência do uso da radiação indica o quanto de matéria seca é produzida por unidade de energia PAR absorvida pela cultura. Sua unidade é $\mathrm{g} \mathrm{MJ}^{-1}$ (Gallo et al., 1993).

A eficiência do uso da radiação é uma das variáveis utilizadas em modelos de estimativa de grãos ou de fitomassa (Monteith, 1972).

Dessa forma, conhecendo-se a radiação fotossinteticamente ativa absorvida acumulada $\left(\mathrm{APAR}_{\mathrm{ac}}\right.$ ) e a produção de fitomassa ou de grãos, pode-se obter o valor da 
eficiência do uso da radiação para a produção de grãos $\left(\varepsilon_{G}\right)$ ou de fitomassa $\left(\varepsilon_{F}\right)$ de uma cultura (Moreira, 1997).

Embora não haja consenso geral, alguns autores tais como como Rawson et al. (1984) e Squire et al. (1984), afirmam que em plantas sadias, bem nutridas e com disponibilidade de água adequada, apresentam um valor constante e maior para a eficiência do uso da radiação $(\varepsilon)$.

Sabe-se ainda que a eficiência fotossintética do aproveitamento da energia solar não é a mesma para todos os dosséis de plantas. A maneira utilizada para medir esta eficiência é através da determinação da produção de fitomassa total ou ainda, de produtos úteis. De modo geral, esta eficiência para as culturas agrícolas é baixa, não atingindo 1\%. Em condições ótimas registram-se eficiências de 3 a 4\%, para as plantas $\mathrm{C}_{3}$ e de 5 a $6 \%$ para as $\mathrm{C}_{4}$ (Machado, 1985).

Por essa razão, é importante conhecer o valor de $\varepsilon$ para cada tipo de cultura e sua variação em relação aos fatores ambientais, culturais e de manejo, pois ela é uma das variáveis de muitos modelos de crescimento e produção de culturas agrícolas, os quais levam em consideração a radiação incidente total, a PAR incidente, a fração PAR absorvida ou interceptada pelo dossel e a eficiência média do uso da radiação ( $\varepsilon$ ) num determinado intervalo de tempo (Moreira, 1997).

\subsection{Comportamento espectral da cultura do feijão irrigada}

Alguns trabalhos referentes ao comportamento espectral da cultura do feijão irrigada têm sido desenvolvidos, e tendo em vista a avaliação do comportamento espectral da cultura e tentativa de se estabelecer relações entre as variáveis espectrais obtidas e as variáveis agronômicas observadas.

Formaggio (1989), tendo como objetivo a verificação dos modos e dos fundamentos das relações entre variáveis agronômicas e variáveis espectrais, para as culturas de trigo e de feijão na região de Guaíra-SP, utilizou como variáveis espectrais os valores de reflectância das 6 bandas refletidas do TM/LANDSAT-5, bem como três 
índices de vegetação: a Razão Simples (RS), a Diferença Normalizada (RND) e o Índice de Vegetação Transformada (RTV). Entre as conclusões obtidas, cita que: (a) existe significativas relações entre características agronômicas dos dosséis e padrões de resposta espectral; (b) as bandas infravermelha e vermelha, bem como os três índices de vegetação podem ser considerados excelentes descritores das condições do trigo e do feijão; (c) as fases do ciclo entre a emergência espectral e o inicio da senescência foliar são as melhores para aquelas relações. Conclui ainda que as curvas obtidas nas bandas $\mathrm{TM}_{3}$ e $\mathrm{TM}_{4}$ permitiram avaliar a dinâmica do comportamento espectral do feijão desde a fase denominada de solo praticamente exposto (curva dos 20 dias), passando por fases intermediárias (32 e 34 dias) no qual observou que o formato das curvas foi progressivamente assumindo a tipicidade do comportamento espectral de vegetação verde vigorosa (destaque aos 38 dias) e chegou-se a fase final do ciclo em que a correspondente curva (92 dias) tomou feições diversas da tipicidade espectral da vegetação verde porém semelhante à fase inicial. $\mathrm{O}$ comportamento espectral típico de vegetação verde vigorosa sensoriado por espectroscopia de campo ocorreu por volta do $38^{\circ}$ dia do ciclo a contar da data de plantio e o tempo de permanência desta tipicidade espectral durou até o $88^{\circ}$ dia do seu ciclo ou seja, por 50 dias.

Epiphanio (1988), trabalhando na região de Guaíra/SP, com dados provenientes do TM/LANDSAT-5 e analisando o comportamento espectral das culturas do trigo e feijão, concluiu que: (a) a cultura do feijão passa a apresentar comportamento espectral típico entre 40 a 50 dias após o plantio; (b) a banda $\mathrm{TM}_{4}$ foi a que se mostrou mais eficiente para as correlações determinadas, embora tenha apresentado baixa utilidade na diferenciação das culturas do feijão e do trigo; (c) o trigo apresenta comportamento espectral típico de vegetação bem antes do que o feijão; (d) a banda $\mathrm{TM}_{7}$ apresentou no referido experimento, o maior poder de discriminação entre o trigo e feijão e para tal análise, a transformação de nível de cinza em reflectância é ineficaz; (e) em geral, maiores correlações entre parâmetros de sensoriamento remoto e parâmetros de cultura (índice de área foliar e percentagem de cobertura do solo) ocorrem para a cultura do feijão e que para tais correlações, a banda $\mathrm{TM}_{4}$ e a razão: $\mathrm{TM}_{5} / \mathrm{TM}_{7}$, apresentaram maior destaque. 
Estudando a cultura do feijão irrigada em campos comerciais situados a nordeste do Estado de São Paulo, Formaggio \& Epiphanio (1990a), e tendo como objetivo trazer subsídios e fundamentações ao entendimento dos relacionamentos existentes entre variáveis espectrais (as seis bandas refletivas TM/Landsat-5 e os índices de vegetação Razão Simples e Diferença Normalizada) e variáveis agronômicas para o feijão, concluíram que as variações índice de área foliar, fitomassa e porcentagem de cobertura vegetal mostraram-se excelentes descritoras das condições gerais de vigor do feijão; assim também as variáveis espectrais $\mathrm{TM}_{3}, \mathrm{TM}_{4}, \mathrm{TM}_{5}$, Razão Simples e Diferença Normalizada, e principalmente nas fases pré-senescência. As variáveis de rendimento não se relacionaram de forma direta com estas variáveis espectrais.

Gleriani (1994), pesquisando a influência do solo de fundo e da geometria da radiação na resposta espectral da cultura do feijão, ao término do experimento concluiu que os solos foram sempre um fator significativo no valor dos três índices; a variação do ângulo zenital de visada não trouxe variação significativa e o horário de medição (variação do ângulo solar) só deixou de ser significativa quando o dossel apresentou uma porcentagem de cobertura vegetal de 100\%. Quanto as relações dos parâmetros agronômicos com o índices de vegetação analisados, o NDVI foi o índice que apresentou o melhor coeficiente de determinação $\left(R^{2}=0,99\right)$ com os parâmetros analisados.

Silva \& Vettorazzi (1997) visando testar a aplicação de imagens digitais do satélite SPOT e dados radiométricos coletados em campo no cadastramento de lavouras irrigadas de feijão carioca, e visando ainda identificar a espécie cultivada e precisar a dimensão da gleba, concluiram que: a) a correlação entre os dados de níveis de cinza extraídos de imagens do satélite Spot e da radiometria de campo não foi satisfatória; b) os dados de radiometria de campo foram mais sensíveis às variações dos fatores fitotécnicos que os dados obtidos a partir das imagens; c) o levantamento e acompanhamento das áreas agrícolas irrigadas pode ser feito com sucesso empregando sensoriamento remoto orbital; d) o cadastramento e identificação de culturas de ciclo anual exploradas em áreas agrícolas irrigadas exige serviços de apoio de campo periódico. 


\section{MATERIAL E MÉTODOS}

\subsection{MATERIAL}

\subsubsection{Local}

O experimento foi conduzido no campo experimental da Escola Técnica em Agropecuária "ETAE Dr. José Coury", pertence ao CEETPS (Centro de Educação Tecnológica Paula Souza), no município de Rio das Pedras - SP e localizado nas proximidades da cidade de Piracicaba, distando cerca de $11 \mathrm{~km}$ desta e cerca de $170 \mathrm{~km}$ da cidade de São Paulo. O local apresenta como coordenadas $22^{\circ} 50^{\prime} 27^{\prime}$ 'S de Latitude e $47^{\circ} 36^{\prime} 39^{\prime \prime} \mathrm{W}$ de Longitude e altitude aproximada de $582 \mathrm{~m}$. O experimento foi instalado em uma área de $32 \mathrm{~m} \times 12 \mathrm{~m}$, com maior declive de $2 \%$ e foi desenvolvido no período de 15 de julho a 19 de outubro de 1999.

A Figura 9 mostra o local em que foi instalado o experimento, onde se observa a cultura do feijão aos 35 dias após o plantio, bem como a divisão das respectivas parcelas.

\subsubsection{Clima}

Segundo o sistema Köppen, o clima de Rio das Pedras é do tipo mesotérmico, Cwa, isto é, subtropical úmido com estiagem no inverno, cujas chuvas do mês mais seco não atingem a $30 \mathrm{~mm}$, mês mais quente com temperatura média superior a $22^{\circ} \mathrm{C}$ e mês mais frio com temperatura média inferior a $18^{\circ} \mathrm{C}$. 


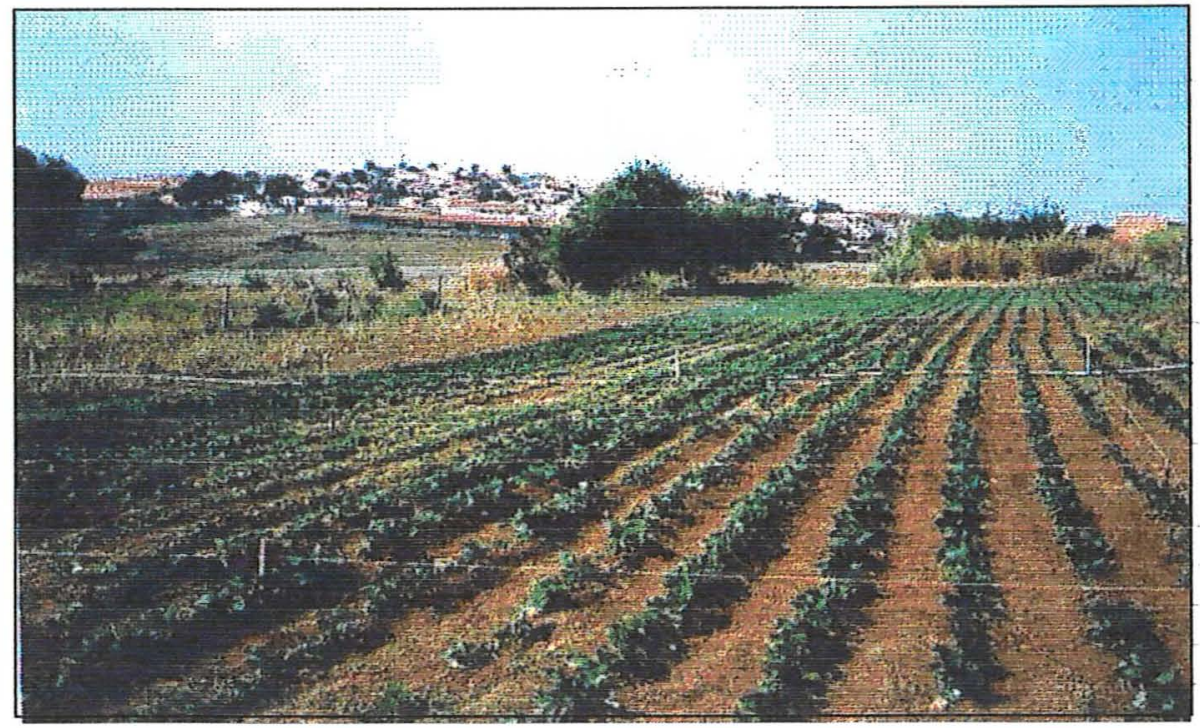

Figura 9 - Local de instalação do experimento, mostrando a cultura do feijão aos 35 dias após o plantio.

As médias de precipitação e temperatura das estações de primavera, verão, outono e inverno são respectivamente: $303 \mathrm{~mm}$ e $20,8^{\circ} \mathrm{C} ; 639 \mathrm{~mm}$ e $23,2^{\circ} \mathrm{C} ; 235 \mathrm{~mm}$ e $20,5^{\circ} \mathrm{C} ; 108 \mathrm{~mm}$ e $16,9^{\circ} \mathrm{C}$. A precipitação anual varia entre 1200 a $1300 \mathrm{~mm}$, ocorrendo a maior parte no verão (de novembro a fevereiro), principalmente com chuvas de alta intensidade e curta duração.

A temperatura mínima da região é da ordem de $10^{\circ} \mathrm{C}$ em julho e a máxima da ordem de $32^{\circ} \mathrm{C}$ em janeiro; a umidade relativa do ar apresenta valores médios em torno de $68 \%$ e a velocidade do vento de $2,5 \mathrm{~m} / \mathrm{s}$ em média.

O Anexo A nos fornece os dados meteorológicos obtidos no transcorrer do experimento através do Posto Agrometeorológico do Departamento de Ciências Exatas ESALQ/USP - Piracicaba, os quais (com exceção das precipitações ocorridas), foram aqueles utilizados no presente trabalho para a caracterização dos parâmetros climáticos necessários. 


\subsubsection{Solo}

O solo no qual foi instalado o experimento é classificado ao nível de grande grupo como Terra Roxa Estruturada e segundo a classificação americana (U.S.D.A., 1975), um Paleudalf óxico, sendo que o material de origem é proveniente de rochas eruptivas básicas.

Para caracterização química do solo foram extraídas amostras, cerca de dois meses antes da instalação do experimento e nas profundidades de $0-20 \mathrm{~cm}$, cujos resultados são apresentados na Tabela 2. A análise química foi realizada no laboratório do Departamento de Solos e Nutrição das Plantas da ESALQ/ USP/ Piracicaba.

Tabela 2. Análise química do solo

\begin{tabular}{|c|c|c|c|c|c|c|c|c|c|c|}
\hline \multirow{2}{*}{$\begin{array}{c}\text { Profundidade } \\
(\mathrm{cm})\end{array}$} & \multirow{2}{*}{$\begin{array}{c}\mathrm{P} \\
\mathrm{mg} / \mathrm{dm}^{3}\end{array}$} & \multirow{2}{*}{$\begin{array}{l}\text { M.O. } \\
\mathrm{g} / \mathrm{dm}^{3}\end{array}$} & K & $\mathrm{Ca}$ & $\mathrm{Mg}$ & $\mathrm{H}+\mathrm{Al}$ & \multirow{2}{*}{$\begin{array}{c}\mathrm{pH} \\
\left(\mathrm{CaCl}_{2}\right)\end{array}$} & \multirow[t]{2}{*}{$\mathbf{S}$} & \multirow[t]{2}{*}{$\mathbf{T}$} & \multirow[t]{2}{*}{ V\% } \\
\hline & & & \multicolumn{4}{|c|}{$\mathrm{mmol}_{/} / \mathrm{dm}^{3}$} & & & & \\
\hline $0-20$ & 88 & 16 & 2,1 & 30 & 12 & 25 & 5,2 & 138 & 600 & 64 \\
\hline
\end{tabular}

Para a caracterização física do solo foram retiradas amostras, antes da instalação do experimento, na profundidade de $0-20 \mathrm{~cm}$ e feitas as seguintes determinações pelo Laboratório de Física de Solos do Departamento de Engenharia Rural da Escola Superior de Agricultura "Luiz de Queiroz" : (a) densidade do solo: utilizando na coleta das amostras indeformadas os cilindros de Uhland com $344,77 \mathrm{~cm}^{3}$; o valor encontrado para a densidade do solo é apresentado na Tabela 3.; (b) análise granulométrica do solo: usando o método de Bouyoucos e classificação textural segundo Lemos \& Santos (1982), conforme os dados presentes na Tabela 3.

Tabela 3. Características físicas do solo para a profundidade de $0-20 \mathrm{~cm}$

\begin{tabular}{|c|c|c|c|c|c|}
\hline \multirow{2}{*}{$\begin{array}{l}\text { Profundidade } \\
\text { (cm) }\end{array}$} & \multicolumn{3}{|c|}{ Granulometria (\%) } & \multirow{2}{*}{$\begin{array}{l}\text { Classe } \\
\text { Textural }\end{array}$} & \multirow{2}{*}{$\begin{array}{c}\text { Densidade globa } \\
\left(\mathrm{g} / \mathrm{cm}^{3}\right)\end{array}$} \\
\hline & Argila & Silte & Areia & & \\
\hline $0-20$ & 47,3 & 12,9 & 39,8 & Argila & 1,48 \\
\hline
\end{tabular}


As curvas de retenção de água do solo foram elaboradas por secamento, em amostras do solo com estrutura indeformada, retiradas com auxílio de um cilindro de volume conhecido nas profundidades de $20 \mathrm{~cm}$ e $30 \mathrm{~cm}$ (como pode ser observado na Figura 10) e submetidas às tensões de $0,2,4,10,30,50,100,300,500$ e $1500 \mathrm{KPa}$, utilizando para tal o funil de placa porosa e a membrana de pressão. Todo o procedimento foi realizado pelo Laboratório de Física de Solos do Departamento de Engenharia Rural da Escola Superior de Agricultura "Luiz de Queiroz"- ESALQ/USP e acompanhado pelo técnico responsável pelo setor, o qual emitiu o relatório final com os respectivos valores encontrados, como nos mostra a Tabela 4.

Tabela 4. Umidade volumétrica $\left(\theta, \mathrm{cm}^{3} / \mathrm{cm}^{3}\right)$ nas diversas tensões $\left(-\psi_{\mathrm{m}}, \mathrm{KPa}\right)$ nas profundidades de 20 e $30 \mathrm{~cm}$ do solo.

\begin{tabular}{|c|c|c|c|c|c|c|c|c|c|c|}
\hline \multirow{2}{*}{$\begin{array}{c}\text { Profundidade } \\
\text { (cm) }\end{array}$} & \multicolumn{10}{|c|}{ Potencial matricial (KPa) } \\
\hline & 0 & 2 & 4 & $10 *$ & 30 & 50 & 100 & 300 & 500 & 1500 \\
\hline 20 & 0,393 & 0,374 & 0,355 & 0,319 & 0,282 & 0,240 & 0,233 & 0,213 & 0,195 & 0,192 \\
\hline 30 & 0,387 & 0,358 & 0,344 & 0,311 & 0,268 & 0,231 & 0,210 & 0,203 & 0,186 & 0,183 \\
\hline
\end{tabular}

* considerou-se como sendo a tensão na capacidade de campo (CC)

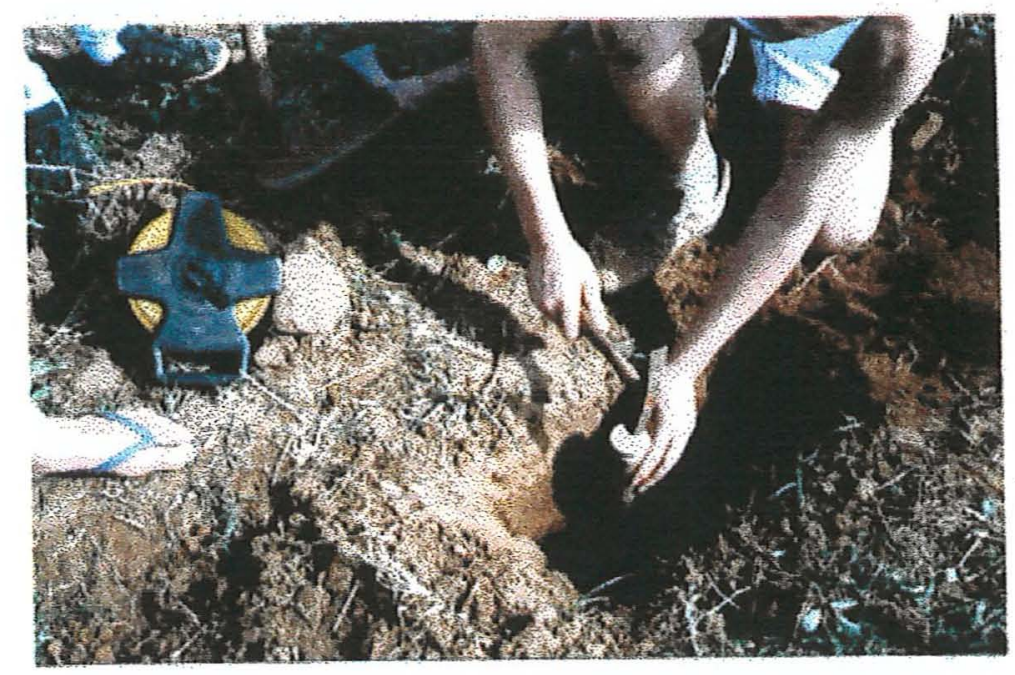

Figura 10 - Coleta de amostra indeformada do solo na profundidade de $30 \mathrm{~cm}$, através do emprego do anel volumétrico. 


\subsubsection{Variedade de feijão utilizada}

No experimento foi utilizado o cultivar de feijoeiro denominada IAC - Carioca 80, produzido e comercializado pela Secretaria de Agricultura de São Paulo, tendo como progenitores os cultivares Carioca e Coronell 49-242. Esta escolha foi baseada no fato deste cultivar ser o mais utilizado pelos agricultores da região em estudo, e apresentar excelente produtividade, além de pouca incidência de pragas e doenças.

O cultivar Carioca 80 apresenta as seguintes características descritas a seguir: planta herbácea, pubescente, com folhas trífoliadas e verdes. Pertence ao grupo diversos, com hábito de crescimento indeterminado (tipo III), guia média a longa, com início de seu florescimento ocorrendo aos 40 - 45 dias após a emergência e ciclo de 90 a 100 dias do plantio à colheita.

Seu sistema radicular de natureza pivotante, apresenta distribuição superficial (80-95\% concentrado nos primeiros $20 \mathrm{~cm}$ do solo); as flores estão dispostas em cachos (rácimos) de cor branca, sendo que a multiplicação predominante é por autofecundação.

Os frutos apresentam características de vagens de coloração verde clara com listras violeta clara, passando a cor de fundo para palha quando secas e com comprimento variável entre 9 a $12 \mathrm{~cm}$ (com 3 a 6 sementes); estas se concentram no terço inferior da planta e apresentam maturação desuniforme.

As sementes de forma oblonga possuem coloração creme marmorizado com listras havana, com ou sem halo alaranjado, sendo que o peso médio de 100 sementes é em torno de $22 \mathrm{~g}$.

O cultivar é resistente a diversas raças do fungo da antracnose e da ferrugem que ocorrem em São Paulo, e ao vírus do mosaico comum.

A Tabela 5 mostra as etapas do desenvolvimento do feijão, com os respectivos intervalos de tempo observados no experimento e a descrição do início de cada uma das etapas, com base em Getps \& Fernandéz (1982), citado por Fancelli (1987). 


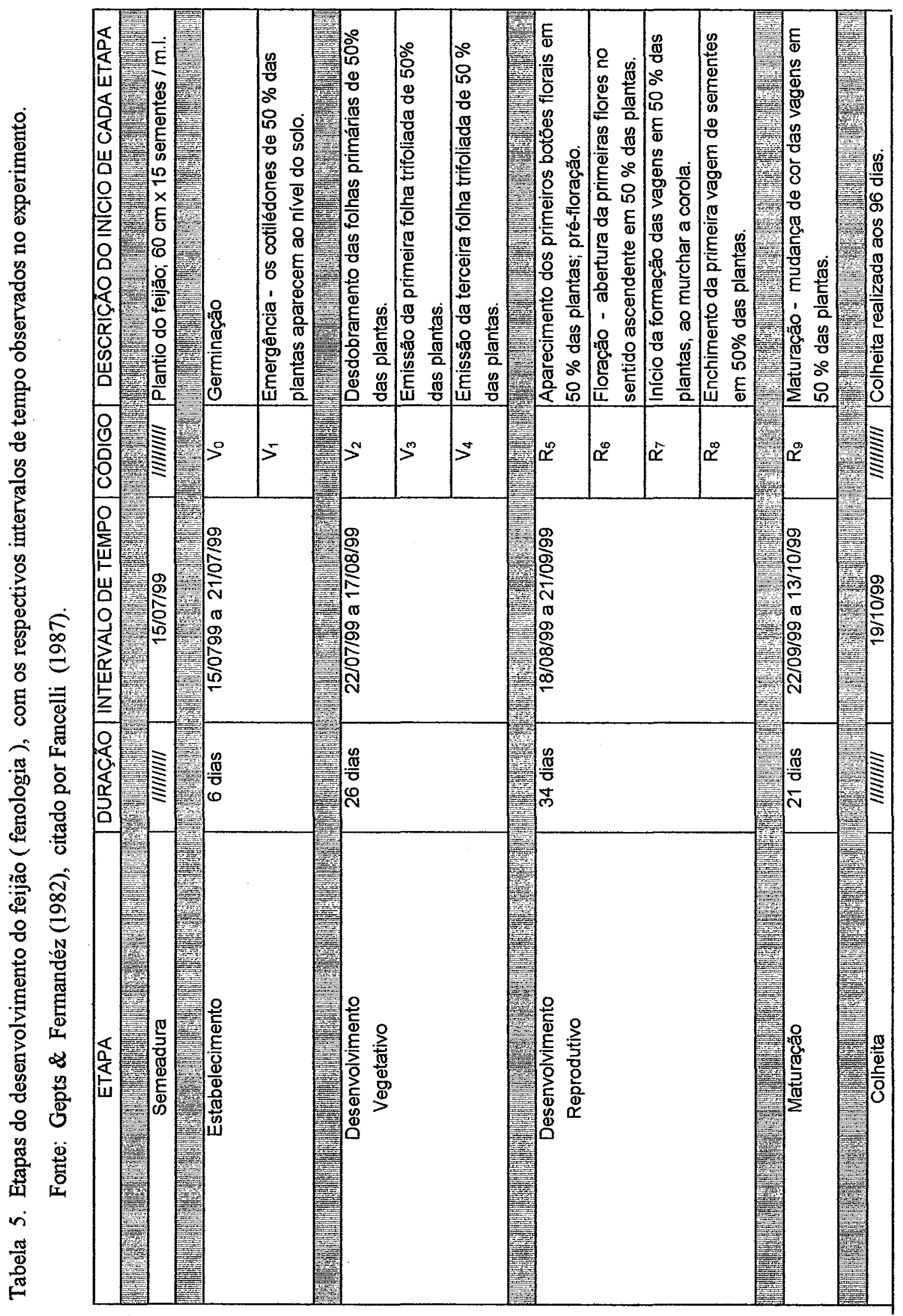




\subsubsection{Sistema de distribuição de água}

A aplicação de água foi realizada com auxílio de um sistema de irrigação por aspersão, disposto no campo segundo o sistema de "aspersão em linha" ("line source sprinkler system"), de acordo com metodologia desenvolvida por Hanks (1976). Este sistema foi idealizado para fins experimentais e consiste na colocação de aspersores estreitamente espaçados em uma única tubulação localizada no centro do campo experimental.

A sobreposição dos jatos e o arranjo dos aspersores em uma única linha, promove maior precipitação junto à linha de aspersão e um gradiente decrescente ao longo da direção perpendicular da área, sendo este efeito denominado de "distribuição triangular da precipitação".

A localização das parcelas experimentais ao longo da direção perpendicular à linha de aspersores, permite a obtenção de diferentes lâminas aplicadas, simulando deste modo, diferentes níveis de irrigação realizados por um sistema convencional de aspersão.

Faria (1981); Azevedo (1984); Folegatti (1988), e um grande número de pesquisadores, trabalhando com diferentes lâminas de água, optaram por esta metodologia em virtude das vantagens que a mesma apresenta, tais como a simplicidade de instalação e operação, grande economia de área, redução no custo de equipamentos e mão-de-obra; permitindo assim um maior número de tratamentos em menor área que o sistema tradicional e possibilitando uma melhor visualização do efeito dos tratamentos no campo.

No experimento foram empregados 5 aspersores de marca Fabrimar, modelo A1823 $(6,0 \times 4,0 \mathrm{~mm})$, devido a sua eficiência para a metodologia adotada nesta pesquisa, conforme indica o trabalho realizado por Oliveira et al. (1997), o qual realizou um ensaio com 14 modelos de aspersores rotativos de média pressão no Laboratório de Irrigação da ESALQ/USP, Piracicaba-SP, com o objetivo de avaliar o padrão de distribuição de água em distintos níveis de pressão de operação, concluindo que o 
referido modelo apresentou os melhores resultados nas pressões testadas, atendendo assim as características de distribuição triangular.

Assim, o aspersor Fabrimar, modelo A1823, operando no experimento a uma pressão de $250,0 \mathrm{KPa}$ e com espaçamento entre aspersores de $6,00 \mathrm{~m}$, produziu um raio de alcance molhado de $13,00 \mathrm{~m}$, obtendo intensidades médias de precipitação de 36,90 $\mathrm{mm} / \mathrm{h} ; 29,11 \mathrm{~mm} / \mathrm{h} ; 22,18 \mathrm{~mm} / \mathrm{h} ; 14,03 \mathrm{~mm} / \mathrm{h} ; 7,40 \mathrm{~mm} / \mathrm{h} ; 2,10 \mathrm{~mm} / \mathrm{h}$ e $0,00 \mathrm{~mm} / \mathrm{h}$, determinadas através de medidas com pluviômetros localizados nas distâncias de 2,00 $\mathrm{m} ; 4,00 \mathrm{~m} ; 6,00 \mathrm{~m} ; 8,00 \mathrm{~m} ; 10,00 \mathrm{~m} ; 12,00 \mathrm{~m} \mathrm{e} 13,00 \mathrm{~m}$ da linha de aspersores, obtendo assim como desejado, um gradiente de precipitação na direção perpendicular à linha de aspersores e semelhante ao encontrado por Hanks (1976).

A Figura 11 mostra a distribuição da precipitação do aspersor em função da distância da linha de aspersão, dados estes obtidos no respectivo experimento.

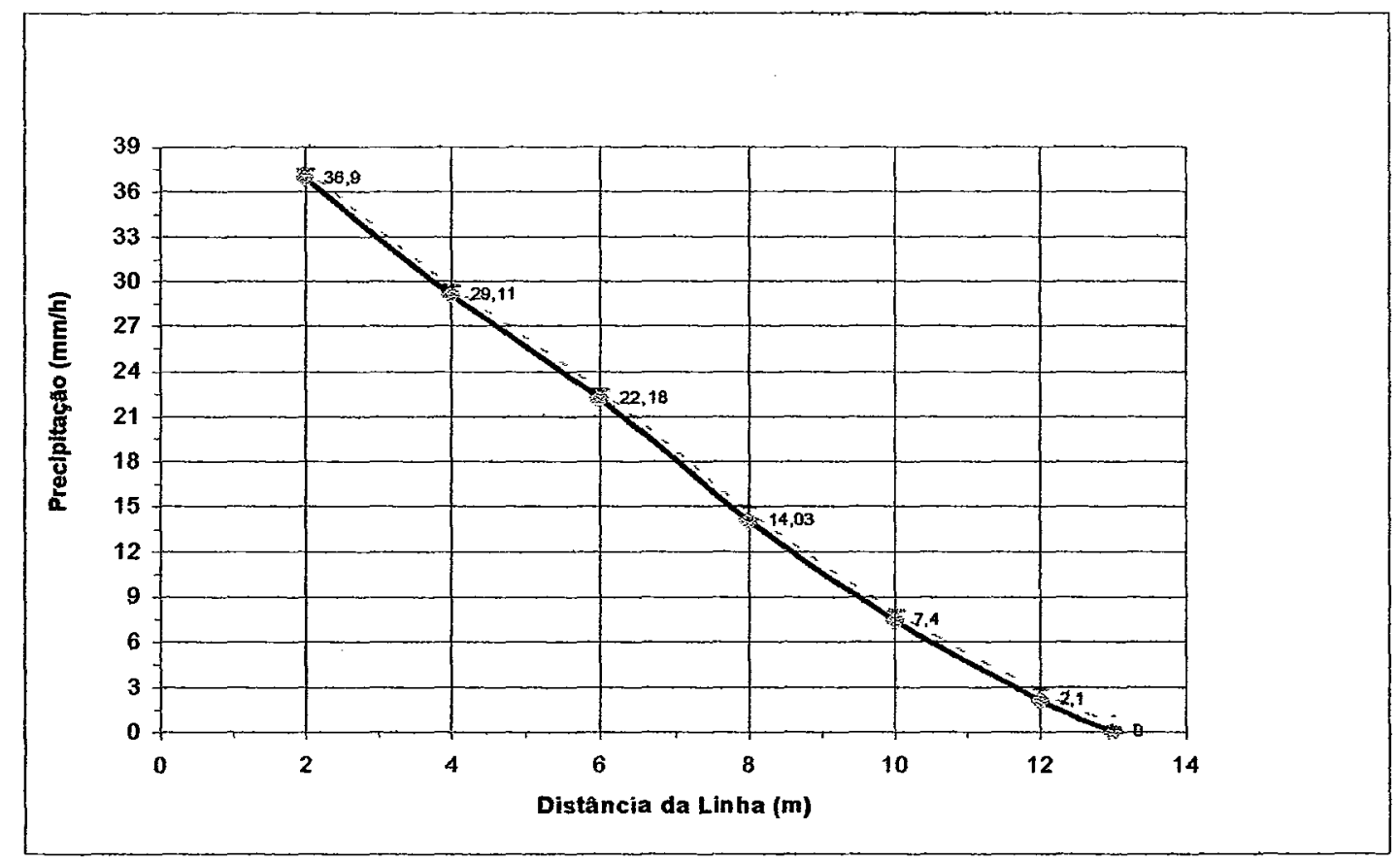

Figura 11 - Distribuição da precipitação do aspersor FABRIMAR / Mod.A1823 (6,0 $\times 4,0 \mathrm{~mm})$, em função da distância da linha de aspersores. 


\subsubsection{Medidas radiométricas sobre o dossel da cultura do feijão}

As medidas radiométricas foram realizadas no desenvolver do experimento através da utilização do espectrorradiômetro portátil SPECTRON SE-590, projetado para medidas em campo e fabricado pela Spectron Engeneering Incorporation, Denver, Colorado, EUA.

Segundo Steffen (1988) e Moreira (1997), o SPECTRON SE-590 consiste de duas unidades básicas: uma controladora (data logger/CE500) e outra detectora (SE390WB), a qual é ligada à unidade controladora por meio de cabos de conexão. A unidade detectora (CE-390), também denominada de cabeça sensora, pode ser ajustada para diversos campos de visada ("field of view "; FOV) através de lentes com diferentes ângulos $\left(1^{\circ}, 6^{\circ}, 15^{\circ}\right.$ ou $\left.180^{\circ}\right)$. Utilizando uma rede de difração, como elemento dispersivo da radiação incidente sobre uma matriz de fotodiodo, a unidade detectora é capaz de registrar, numa fração de tempo que varia de $1 / 60$ s até $64 / 60$ s, informações sobre as características radiométricas do alvo em 256 bandas de aproximadamente $2,7 \mathrm{~nm}$ cada, na faixa espectral de $400 \mathrm{~nm}$ a $1100 \mathrm{~nm}$ do espectro eletromagnético.

A unidade controladora (CE-500) contém um microprocessador que permite programar o sistema, através de um teclado multinível, para a aquisição de espectros simples (uma única medida da radiância espectral do alvo), médios (média de várias medidas da radiância espectral do alvo) ou seqüenciais (medidas da radiância espectral em intervalos pré definidos), bem como, introduzir indicadores tais como data, hora e número de identificação nos dados adquiridos. Possui ainda um gravador digital "12 bit" que permite gravação e leitura dos dados em uma fita cassete digital do tipo miniatura. A unidade controladora é também utilizada na formatação e na transferência dos espectros para periféricos de saídas como: osciloscópio, traçador gráfico e impressora matricial.

Para operar em condições de campo, o sistema utiliza como fonte de energia uma bateria recarregável de $12 \mathrm{v}$. Um conversor AC/DC é usado para o recarregamento da bateria interna ou a operação do sistema à partir da rede de $110 / 220 \mathrm{v}$. Uma via serial RS-232C permitiu a transferência dos dados adquiridos pelo espectrorradiômetro para 
um computador onde os dados foram analisados através de um programa computacional específico denominado "ESPECTRO", programa este desenvolvido em São José dos Campos, no Laboratório de Radiometria do INPE (LARAD), e cujo objetivo é transferir e manipular os dados coletados pelo SPECTRON SE-590. O referido programa também permitiu a geração de arquivos em formato ASCII para tratamento dos dados em outros aplicativos.

No respectivo trabalho foram utilizadas duas unidades detectoras, ligadas a unidade controladora por cabos de conexão. Nesta configuração, pode-se registrar dois espectros de forma quase simultânea, sendo que um dos espectros correspondeu a radiância de uma amostra de área sobre o dossel da cultura do feijão (alvo) e o outro, correspondeu à radiância da placa de referência (Sulfato de Bário). As medidas da radiância quase que simultaneamente, do alvo e da placa, foram utilizadas para obter o fator de reflectância. As unidades detectoras foram montadas num mastro de alumínio a uma altura aproximada de 3 metros acima da cultura. Estas, apresentaram seus eixos ópticos orientados de forma paralela, sendo uma das unidades posicionada para o dossel da cultura, utilizando-se o campo de visada de $15^{\circ}$, e a outra unidade com campo de visada de $6^{\circ}$ foi posicionada sobre a placa de referência, fixada a $15 \mathrm{~cm}$ abaixo da unidade detectora, conforme é ilustrado na Figura 12.

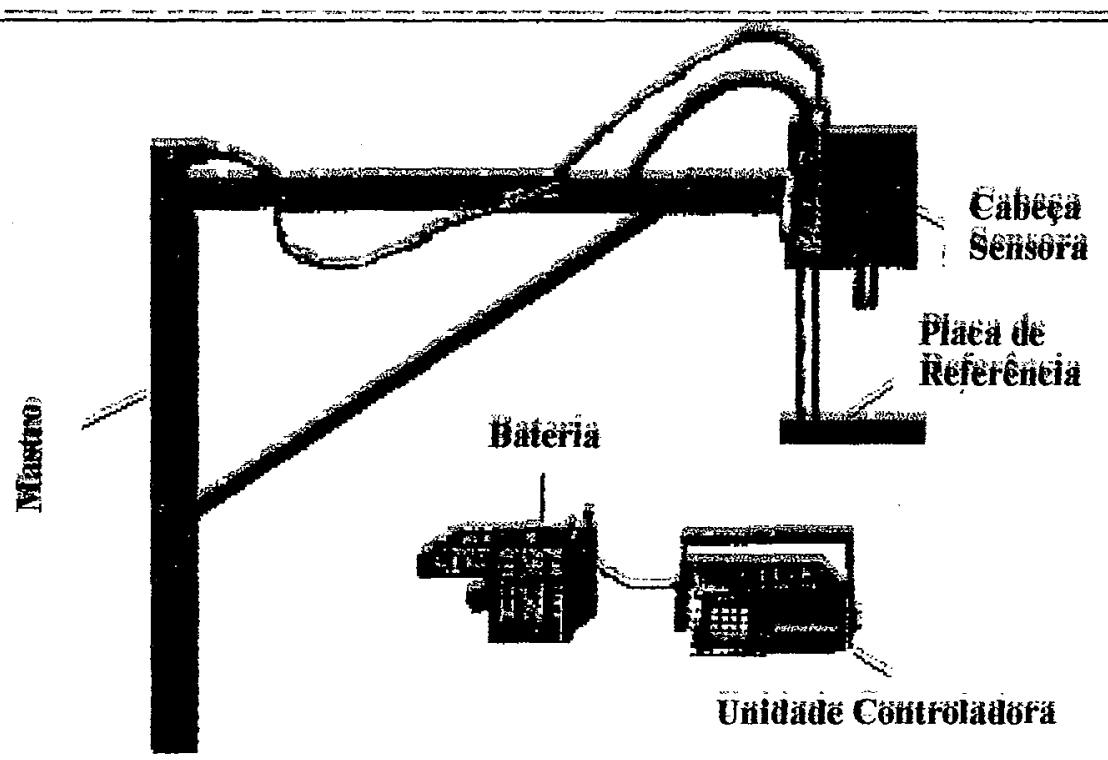

Figura 12 - Esquema de obtenção de medida da radiância para a aquisição do fator de reflectância do feijão em condições de campo. Fonte: Steffen (1995). 


\subsection{MÉTODOS}

\subsubsection{Delineamento experimental}

O delineamento experimental foi em blocos não casualisados, com a utilização de 4 tratamentos e 6 repetições, sendo as repetições em número de 3 de cada lado da linha de aspersores, perfazendo um total de 24 parcelas ( conforme mostra a Figura 13).

Os tratamentos constaram de quatro lâminas de irrigação, denominados de $\mathrm{T}_{\mathbf{4}}$ $(209,00 \mathrm{~mm}), T_{3}(124,00 \mathrm{~mm}) ; T_{2}(42,00 \mathrm{~mm})$ e a testemunha $T_{1}(0,0 \mathrm{~mm})$, correspondentes às parcelas localizadas a distâncias de $0,0 \mathrm{~m}$ a $4,0 \mathrm{~m} ; 4,00 \mathrm{~m}$ a 8,00 $\mathrm{m} ; 8,00 \mathrm{~m}$ a $12,00 \mathrm{~m}$ e $12,00 \mathrm{~m}$ a $16,00 \mathrm{~m}$ da linha de aspersores. Os valores da lâmina total recebida pelos diferentes tratamentos durante todo o período experimental foi $o$ resultado da somatória das aplicações realizadas com o sistema de aspersão em linha, precipitação pluvial acumulada $(114,40 \mathrm{~mm})$ e irrigações uniformes no estágio inicial da cultura $(50,00 \mathrm{~mm})$.

Cada uma das parcelas apresentou dimensões iguais a 4,00 $\mathrm{m}$ de largura por 4,00 $\mathrm{m}$ de comprimento, com área total de $16,00 \mathrm{~m}^{2}$. Considerou-se uma bordadura de $0,40 \mathrm{~m}$ no sentido do comprimento de cada parcela e de $0,40 \mathrm{~m}$ no sentido da largura, resultando em uma parcela útil de 3,20 $\mathrm{m}$ de comprimento por $3,20 \mathrm{~m}$ de largura, com área útil igual a $10,24 \mathrm{~m}^{2}$.

As chuvas e irrigações foram coletadas em pluviômetros, instalados no centro das parcelas $2,5,8,11,14,17,20$ e 23 .

Para o controle da irrigação foram utilizadas baterias de tensiômetros de mercúrio, os quais foram instalados nas profundidades de $20 \mathrm{~cm}, 30 \mathrm{~cm}$ e $40 \mathrm{~cm}$, nas parcelas 7,8,9,16, 17 e 18 (correspondentes ao tratamento $\mathrm{T}_{3}$ ).

A Figura 13 mostra a disposição da linha de aspersores colocada no centro da área, dividindo-a em duas partes e paralela à direção das linhas de plantas, bem como os locais onde foram instalados os pluviômetros e as baterias de tensiômetros. 


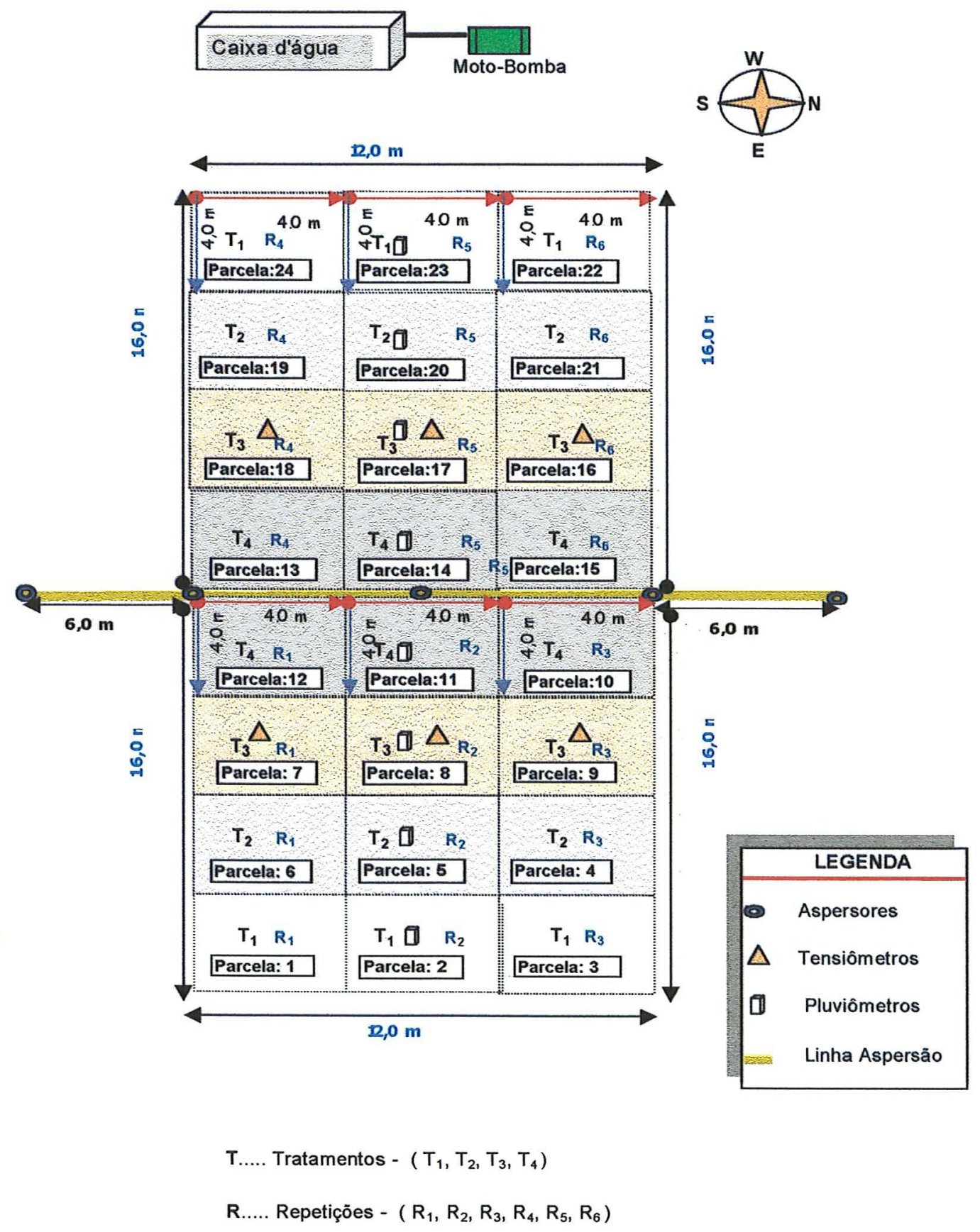

Figura 13 - Esquema do delineamento experimental. 


\subsubsection{Preparo do solo e semeadura}

O preparo do solo constituiu de uma aração realizada em 20/06/99 e de duas gradagens, as quais foram realizadas nas datas de12/07/99 e 14/07/99.

A semeadura foi realizada mecanicamente em 15/07/99, sendo adotado o espaçamento de $60 \mathrm{~cm}$ entre os sulcos e uma densidade de plantio de 15 sementes por metro linear, o que permitiu obter um "stand" da ordem de 200.000 plantas/ha, o que corresponde a aproximadamente 12 plantas por metro linear. A colheita dos tratamentos foi realizada manualmente em 19/10/99, quando a cultura apresentava 96 dias de idade em relação a data de plantio.

Não foi realizada a calagem do solo para o plantio do feijão, devido o valor do índice de saturação em bases (V\%), na profundidade amostrada de $0-20 \mathrm{~cm}$, ser considerado alto $(\mathrm{V} \%=64 \%$ ), conforme mostra a Tabela 2 . Esse procedimento foi baseado nas recomendações da Coordenadoria de Assistência Técnica Integral - CATI (1994), Boletim 216; o qual recomenda a dispensa da calagem do solo para a cultura do feijão, toda vez que o solo acusar um $\mathrm{V} \%>60 \%$.

A adubação de plantio foi feita com base na análise química do solo (Tabela 2), utilizando-se a mistura de adubos na fórmula 04-14-08 e na dose de $270 \mathrm{~kg} / \mathrm{ha}$ em $15 / 07 / 99$, o que corresponde a $10,8 \mathrm{~kg}$ de nitrogênio $(\mathrm{N}), 37,8 \mathrm{~kg}$ de fósforo $\left(\mathrm{P}_{2} \mathrm{O}_{5}\right)$ e $21,6 \mathrm{~kg}$ de potássio $\left(\mathrm{K}_{2} \mathrm{O}\right)$ por hectare.

Após 25 dias do plantio (10/08) fez-se uma adubação em cobertura na dose de $40 \mathrm{~kg} / \mathrm{ha}$ de nitrogênio, na superfície do solo e ao lado da planta, em forma de sulfato de amônia.

\subsubsection{Tratos culturais e controle de pragas e moléstias}

A cultura do feijão foi mantida livre de ervas daninhas até o periodo de florescimento das plantas e através da realização de 4 capinas manuais realizadas nas datas de 04/08, 11/08, 18/08 e 23/08. Após esse período, não mais se realizou qualquer 
cultivo em virtude do estabelecimento da cultura e respectiva cobertura vegetal de boa parte do terreno, o que torna essa prática desnecessária, segundo as recomendações agronômicas.

O controle fitossanitário foi realizado com pulverizações manuais do inseticida Decis (piretróide), na dosagem de $6 \mathrm{ml}$ do produto/ 20 litros de água, em três aplicações preventivas nas datas de 04/08, 18/08 e 01/09, visando o combate de algumas pragas da cultura como a mosca branca e a cigarrinha. Foi ainda utilizado de forma preventiva o fungicida Manzate $\mathrm{D}$, na dosagem de $20 \mathrm{~g}$ do produto/20 litros de água, em pulverizações realizadas nas datas de $11 / 08,25 / 08$ e 10/09, visando um controle preventivo da ferrugem e da antracnose, sendo estas suficientes para manter as plantas isentas de patógenos durante todo o transcorrer do experimento.

\subsubsection{Controle da irrigação}

O fundamento básico do controle de irrigação adotado foi o de que o sistema agrícola deve ser visualizado como um todo, considerando a interação das três fases (solo, planta e atmosfera) entre si e com o meio que as cercam.

Inicialmente, após a semeadura em 15/07/99 e nos primeiros 26 dias, foram feitas irrigações uniformes em todos os tratamentos, a fim de padronizar a emergência das plantas, como recomenda Azevedo (1984). Para este procedimento, utilizou-se um sistema de aspersão disposto dentro de um espaçamento de $12 \mathrm{~m} \times 12 \mathrm{~m}$, aplicando-se uma lâmina total de $50,0 \mathrm{~mm}$ durante este período, em 5 irrigações de $10,0 \mathrm{~mm}$ cada e realizadas nos dias 16/07, 22/07, 28/07, 03/08 e 09/08 (Figura 14).

Efetivamente, em 14/08/99 iniciou-se o controle das lâminas de água irrigadas, utilizando-se o sistema de aspersão em linha e aplicando-se a partir desse momento e até o fim do ciclo da cultura em cada uma das irrigações realizadas, as seguintes lâminas de irrigação: $20,90 \mathrm{~mm} ; 12,40 \mathrm{~mm} ; 4,19 \mathrm{~mm}$ e $0,0 \mathrm{~mm}$, respectivamente nas parcelas correspondentes aos tratamentos $T_{4}, T_{3}$ (controle), $T_{2}$ e $T_{1}$. 
O controle da lâmina aplicada nos vários tratamentos e durante todo o período experimental, foi realizado através de pluviômetros instalados no centro das parcelas 2 , $5,8,11,14,17,20$ e 23, pluviômetro este com capacidade de 1 litro e apresentando área de captação de $53 \mathrm{~cm}^{2}$, resultando assim em uma relação volume/lâmina de $5,3 \mathrm{ml} / \mathrm{mm}$.

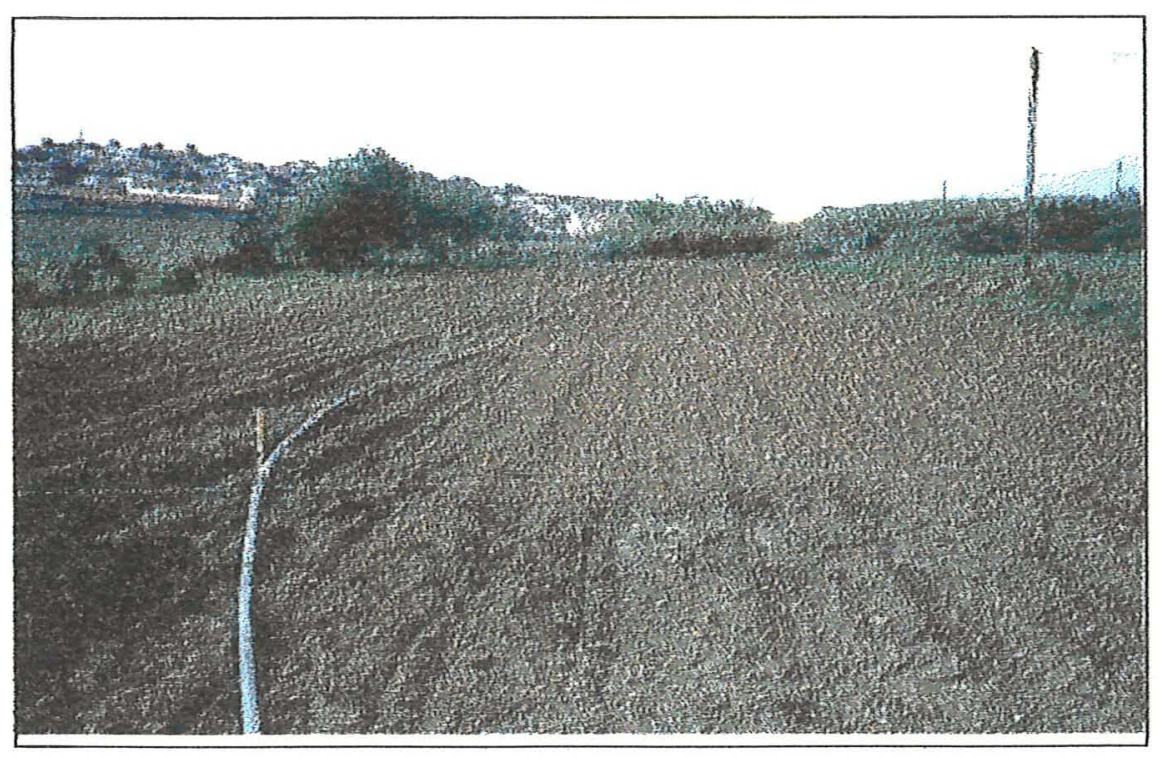

Figura 14 - Sistema de irrigação convencional permitindo irrigações uniformes em todos os tratamentos, visando padronizar a germinação. Cultura aos 3 dias após o plantio.

A lâmina total recebida em cada tratamento durante o ciclo da cultura foi obtida através da somatória das irrigações realizadas e da precipitação ocorrida durante esse período. As lâminas aplicadas em cada tratamento e as datas correspondentes, bem como as precipitações observadas durante o período de condução do ensaio encontram-se na Tabela 6 , onde verifica-se a ocorrência de precipitações consideráveis no período de 08/09 a 15/09, quando o feijão encontrava-se na fase de desenvolvimento reprodutivo e extremamente sensível a qualquer déficit hídrico. Outras três precipitações ocorreram no período de 07/10 a 17/10, precipitações estas que coincidiram com o estágio final de maturação, o que acarretou em um pequeno atraso na colheita. 
Tabela 6. Lâminas aplicadas através da irrigação e precipitação pluvial (mm) ocorrida nos tratamentos $1,2,3$ e 4 .

\begin{tabular}{|c|c|c|c|c|}
\hline \multirow[t]{2}{*}{ DATA } & \multicolumn{4}{|c|}{ TRATAMENTOS } \\
\hline & 1 & 2 & 3 & 4 \\
\hline $16 / 07$ & 10,0 (i) & 10,0 (i) & 10,0 (i) & 10,0 (i) \\
\hline $22 / 07$ & $10,0(\mathrm{i})$ & 10,0 (i) & 10,0 (i) & $10,0(\mathrm{i})$ \\
\hline $28 / 07$ & $10,0(\mathrm{i})$ & 10,0 (i) & $10,0(\mathrm{i})$ & $10,0(\mathrm{i})$ \\
\hline $03 / 08$ & 10,0 (i) & 10,0 (i) & 10,0 (i) & $10,0(\mathrm{i})$ \\
\hline $09 / 08$ & 10,0 (i) & $10,0(\mathrm{i})$ & 10,0 (i) & $10,0(\mathrm{i})$ \\
\hline $14 / 08$ & $* * * * * * * *$ & 4,2 (i) & 12,4 (i) & 20,9 (i) \\
\hline $18 / 08$ & $* * * * * * * *$ & $4,2(\mathrm{i})$ & 12,4 (i) & $20,9(i)$ \\
\hline $23 / 08$ & $* * * * * * * *$ & 4,2 (i) & $12,4(\mathrm{i})$ & $20,9(\mathrm{i})$ \\
\hline $27 / 08$ & $* * * * * * * *$ & 4,2 (i) & 12,4 (i) & $20,9(\mathrm{i})$ \\
\hline $02 / 09$ & $* * * * * * * *$ & $4,2(\mathrm{i})$ & $12,4(\mathrm{i})$ & $20,9(\mathrm{i})$ \\
\hline $07 / 09$ & $* * * * * * * *$ & 4,2 (i) & 12,4 (i) & 20,9 (i) \\
\hline $08 / 09$ & $24,0(p)$ & $24,0(p)$ & $24,0(p)$ & $24,0(\mathrm{p})$ \\
\hline $09 / 09$ & $19,5(\mathrm{p})$ & $19,5(p)$ & $19,5(p)$ & $19,5(p)$ \\
\hline $11 / 09$ & $6,5(p)$ & $6,5(\mathrm{p})$ & $6,5(p)$ & $6,5(p)$ \\
\hline $12 / 09$ & $14,5(p)$ & $14,5(p)$ & $14,5(p)$ & $14,5(\mathrm{p})$ \\
\hline $14 / 09$ & $15,0(p)$ & $15,0(p)$ & $15,0(p)$ & $15,0(p)$ \\
\hline $15 / 09$ & $9,5(p)$ & $9,5(p)$ & $9,5(\mathrm{p})$ & $9,5(p)$ \\
\hline $20 / 09$ & $* * * * * * * *$ & 4,2 (i) & 12,4 (i) & $20,9(\mathrm{i})$ \\
\hline $24 / 09$ & $* * * * * * * *$ & 4,2 (i) & 12,4 (i) & 20,9 (i) \\
\hline $29 / 09$ & $* * * * * * * *$ & 4,2 (i) & 12,4 (i) & 20,9 (i) \\
\hline $02 / 10$ & $* * * * * * * *$ & 4,2 (i) & 12,4 (i) & $20,9(\mathrm{i})$ \\
\hline $07 / 10$ & $11,0(p)$ & $11,0(p)$ & $11,0(p)$ & $11,0(p)$ \\
\hline $16 / 10$ & $4,3(p)$ & $4,3(p)$ & $4,3(\mathrm{p})$ & $4,3(\mathrm{p})$ \\
\hline $17 / 10$ & $10,1(p)$ & $10,1(p)$ & $10,1(p)$ & $10,1(\mathrm{p})$ \\
\hline Vy & 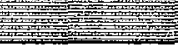 & 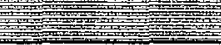 & 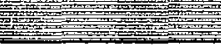 & $8=3$ \\
\hline TOTAL $(\mathrm{mm})$ & 164,4 & 206,4 & 288,4 & 373,4 \\
\hline
\end{tabular}

(i) - irrigação (mm)

(p) - precipitação pluvial $(\mathrm{mm})$

Para controle da irrigação utilizou-se seis baterias de tensiômetros, instaladas nas parcelas $7,8,9,16,17,18$, a uma distância aproximada de 6 metros da linha de aspersão, correspondentes ao tratamento $\mathrm{T}_{3}$, e com a finalidade de acompanhar $o$ potencial matricial da água do solo nos vários estágios de desenvolvimento da cultura. 
A escolha do tratamento $T_{3}$ como controle, foi realizada em função de se monitorar a lâmina média obtida no experimento e possibilitando assim um melhor controle sobre os níveis de irrigação, diminuindo dessa forma a possibilidade de se minimizar ou maximizar a lâmina exigida pela cultura.

Em cada uma dessas baterias, foram utilizados três tensiômetros, os quais utilizaram o mercúrio como líquido indicador manométrico. Estes foram instalados na linha da cultura e de tal forma que o centro geométrico da cápsula porosa estivesse a 20 $\mathrm{cm}, 30 \mathrm{~cm}$ e $40 \mathrm{~cm}$ abaixo da superficie do terreno. As leituras dos tensiômetros foram feitas diariamente as 8:00 horas.

Nos primeiros 35 dias da cultura, utilizou-se os tensiômetros instalados a $20 \mathrm{~cm}$ de profundidade como indicadores do potencial matricial da água do solo. Após esse período, e para a definição do momento de irrigação, foram utilizados os tensiômetros instalados a $30 \mathrm{~cm}$ de profundidade, para informações de umidade e potencial mátrico do solo, visto esta profundidade ser representativa de mais de $90 \%$ do comprimento do sistema radicular da cultura do feijão (Reichardt, 1990).

Os parâmetros obtidos e referentes a determinação da curva de retenção de água do solo nas profundidades de 20 e $30 \mathrm{~cm}$ para o tratamento $T_{3}$ são apresentados na Tabela 7, parâmetros estes que foram extrapolados por meio do método de Dourado Neto et al. (1990).

Tabela 7 - Parâmetros referentes a determinação da curva de retenção de água do solo nas profundidades de 20 e $30 \mathrm{~cm}$ e extrapolados do método de Dourado Neto et al. (1990).

\begin{tabular}{|cccccc|}
\hline $\begin{array}{c}\text { Profundidade } \\
(\mathrm{cm})\end{array}$ & $\begin{array}{c}\text { Umidade } \\
\text { Residual } \\
\left(\theta_{\mathrm{z}}, \mathrm{cm}^{3} / \mathrm{cm}^{3}\right)\end{array}$ & $\begin{array}{c}\text { Umidade } \\
\text { Saturação } \\
\left(\theta_{\mathrm{s}}, \mathrm{cm}^{3} / \mathrm{cm}^{3}\right)\end{array}$ & $\begin{array}{c}\text { Inverso da } \\
\text { Tensão } \\
\left(\alpha, \mathrm{cm}^{-1}\right)\end{array}$ & $\mathbf{n}$ & $\mathrm{m}$ \\
\hline 20 & 0,185 & 0,392 & 0,0048 & 0,8725 & 1,0068 \\
30 & 0,176 & 0,394 & 0,0037 & 0,7690 & 1,2879 \\
\hline
\end{tabular}


De posse dos parâmetros referentes a determinação da curva de retenção de água do solo nas profundidades de 20 e $30 \mathrm{~cm}$ (Tabela 7), realizou-se então o cálculo da umidade do solo $\left(\theta, \mathrm{cm}^{3} / \mathrm{cm}^{3}\right)$ para o tratamento $T_{3}$, correspondente ao potencial mátrico $(\psi, \mathrm{KPa})$, através do modelo proposto por van Genutchen (1980), equação esta que permite o ajuste da curva com base na análise de regressão não linear, minimizando a soma dos quadrados dos desvios residuais. A referida equação é dada abaixo (Eq.6) :

$$
\theta(\psi)=\theta r+\frac{(\theta s-\theta r)}{\left.\left[1+(\alpha \cdot \psi)^{\mathrm{n}}\right]^{\mathrm{m}}\right]}
$$

em que: $\theta \mathrm{r}$ é a umidade residual $\left(\mathrm{cm}^{3} / \mathrm{cm}^{3}\right)$, $\theta$ s é a umidade de saturação $\left(\mathrm{cm}^{3} / \mathrm{cm}^{3}\right)$, $\alpha$ é o inverso da tensão $\left(\mathrm{cm}^{-1}\right), \mathrm{n}$ e $\mathrm{m}$ são parâmetros adimensionais $\mathrm{e}, \psi$ é o potencial mátrico da água no solo $(\mathrm{KPa})$.

Assumindo-se ainda que no exato momento da leitura da altura do mercúrio, no manômetro do tensiômetro, existe um equilíbrio hidrostático não há perda de água do tensiômetro para o solo e vice-versa), calculou-se o potencial mátrico $(\psi, \mathrm{KPa})$ da água do solo, através da seguinte expressão:

$$
\psi=-12,6 \mathrm{~h}+\mathrm{h}_{1}+\mathrm{h}_{2}
$$

em que: $\psi$ é o potencial mátrico da água no solo (KPa), h é a altura da coluna de mercúrio (cm), $h_{1}$ é a altura do nível de mercúrio em relação ao solo $(\mathrm{cm})$ e, $\mathrm{h}_{2}$ é a profundidade de instalação do tensiômetro $(\mathrm{cm})$.

A lâmina líquida de irrigação foi por fim calculada com o auxílio da curva de retenção da água do solo, onde o critério usado foi o de repor a água necessária nas parcelas relativas ao tratamento $T_{3}$ (controle), para que a umidade do solo nestas e quando correspondente a $-21,2 \mathrm{KPa}$ retornasse a umidade correspondente a capacidade 
de campo e igual a $-10,0 \mathrm{KPa}$. Dessa forma, procurou-se trabalhar em uma faixa não inferior a $74 \%$ do total de água disponível para o tratamento $\mathrm{T}_{3}$ e de forma a garantir $\mathrm{o}$ pleno desenvolvimento da cultura.

A equação utilizada para o cálculo da lâmina líquida de irrigação (L) é dada através da Equação 8, a qual é dada abaixo:

$$
L=\frac{[\theta(c c)-\theta(x)] . H}{E_{i}}
$$

em que: $\mathrm{L}$ é a lâmina líquida de irrigação $(\mathrm{mm}), \theta(\mathrm{cc})$ é a umidade volumétrica do solo na tensão correspondente a $-10,0 \mathrm{KPa}\left(\mathrm{cm}^{3}\right.$ água $/ \mathrm{cm}^{3}$ solo), $\theta(\mathrm{x})$ é a umidade volumétrica do solo na tensão correspondente a $-21,2 \mathrm{KPa}\left(\mathrm{cm}^{3}\right.$ água/ $\mathrm{cm}^{3}$ solo), $\mathrm{H}$ é a camada de solo que se deseja irrigar $(30 \mathrm{~cm})$ e, $\mathrm{E}_{\mathrm{i}}$ a eficiência da irrigação considerada $(80 \%)$

Foi também criado um programa computacional específico para realizar os cálculos necessários ao controle da irrigação. Através deste programa, se pode concluir que tendo com referência o tratamento $\mathrm{T}_{3}$ e de acordo com os valores obtidos através da curva de retenção da água do solo e posterior aplicação na equação de van Genutchen (1980), bem como das condições locais referentes a tensiometria, a irrigação se tornaria necessária sempre que a coluna de mercúrio nos tensiômetros instalados a $30 \mathrm{~cm}$ de profundidade, indicassem uma média de altura igual a $20 \mathrm{~cm}$; altura esta correspondente a uma tensão da água no solo igual a $-21,2 \mathrm{KPa}$ e equivalente a $74 \%$ da água disponível presente nas parcelas representativas do tratamento $T_{3}$. Dessa forma, se fez necessária segundo o programa, uma lâmina irrigada igual a $12,38 \mathrm{~mm}$ para elevar a umidade atual do solo $\left(\theta(x)=0,276 \mathrm{~cm}^{3} / \mathrm{cm}^{3}\right)$ e correspondente a uma tensão da água igual a $-21,2$ $\mathrm{KPa}$, para o ponto de capacidade de campo, onde a umidade apresentou um valor igual a $\left(\theta(\mathrm{cc})=0,309 \mathrm{~cm}^{3} / \mathrm{cm}^{3}\right)$ e correspondente a uma tensão de $-10,0 \mathrm{KPa}$. 
Para aplicar essa lâmina, foi calculado pelo referido programa que seria preciso um tempo de funcionamento da linha de aspersão igual a 34 minutos. O programa computacional denominado "Equação de van Genutchen - cálculo da lâmina de irrigação " é apresentado no Anexo B.

\subsubsection{Medidas radiométricas}

Durante os 96 dias em que a cultura do feijão permaneceu no campo, foram realizadas 10 campanhas radiométricas, sendo que a primeira foi feita na data de 19 de julho (4 dias após o plantio), época em que a cultura se encontrava nas etapas de germinação $\left(V_{0}\right)$ e início de emergência $\left(V_{1}\right)$. A última campanha radiométrica foi feita na data de 12 de outubro, quando a cultura se encontrava aos 89 dias após o plantio, em plena maturação e onde foi observada a mudança de cor das vagens em mais de $50 \%$ das plantas (correspondente ao estádio $\mathrm{R}_{9}$ ).

As medidas radiométricas após serem processadas no computador e utilizando o programa "ESPECTRO", programa este desenvolvido pelo Laboratório de Radiometria do INPE (LARAD), foram trabalhadas com o intuito de se obter os valores do fator de reflectância (FR) correspondentes as bandas $\mathrm{TM}_{3}$ e $\mathrm{TM}_{4}$ do satélite Landsat, bem como os valores do índice de vegetação diferença normalizada (NDVI) de cada uma das campanhas realizadas (Anexo $\mathrm{C}$ ), para posterior cálculo da APAR, e tendo em vista as diferentes lâminas de água aplicadas. As respectivas datas onde a radiometria de campo foi realizada e a idade da cultura nestas, podem ser observadas na Tabela 8 .

Tabela 8. Datas em que foram obtidas no campo as medidas radiométricas do dossel da cultura do feijão e respectiva idade da cultura em dias.

\begin{tabular}{|lcccccccccc|}
\hline Data & $19 / 7$ & $5 / 8$ & $13 / 8$ & $26 / 8$ & $3 / 9$ & $13 / 9$ & $21 / 9$ & $28 / 9$ & $5 / 10$ & $12 / 10$ \\
\hline Dia Juliano & 200 & 217 & 225 & 238 & 246 & 256 & 264 & 271 & 278 & 285 \\
\hline Idade (dias) & 4 & 21 & 29 & 42 & 50 & 60 & 68 & 75 & 82 & 89 \\
\hline
\end{tabular}


As medidas radiométricas foram executadas segundo um esquema préestabelecido, em dias claros e sem nuvens, possibilitando condições de céu aberto para que se tivesse o máximo de radiação solar incidente e sempre no período compreendido entre 11:30 e 12:30 horas. Em cada uma das campanhas realizadas foi adotado o mesmo procedimento, isto é: (a) em primeiro lugar foi obtido o par de medidas da radiância da placa de referência (Sulfato de Bário), com as duas unidades detectoras, para realização posterior da intercalibração durante o tratamento dos dados no computador; (b) em seguida, a placa de referência era redirecionada para a cabeça de $6^{\circ}$, onde permaneceria até o final da coleta dos dados; (c) após, o mastro era direcionado em uma posição prédeterminada em cada parcela, de forma que as medidas da radiância do dossel do feijão fossem obtidas em dois locais diferentes dentro da mesma parcela e intercaladas com as medidas tomadas na placa de referência. O local de tomada das medidas em cada parcela foi marcado por piquetes, de forma que as medidas em todas as campanhas foram sempre tomadas nos mesmos locais e de maneira semelhante (Figura 15).

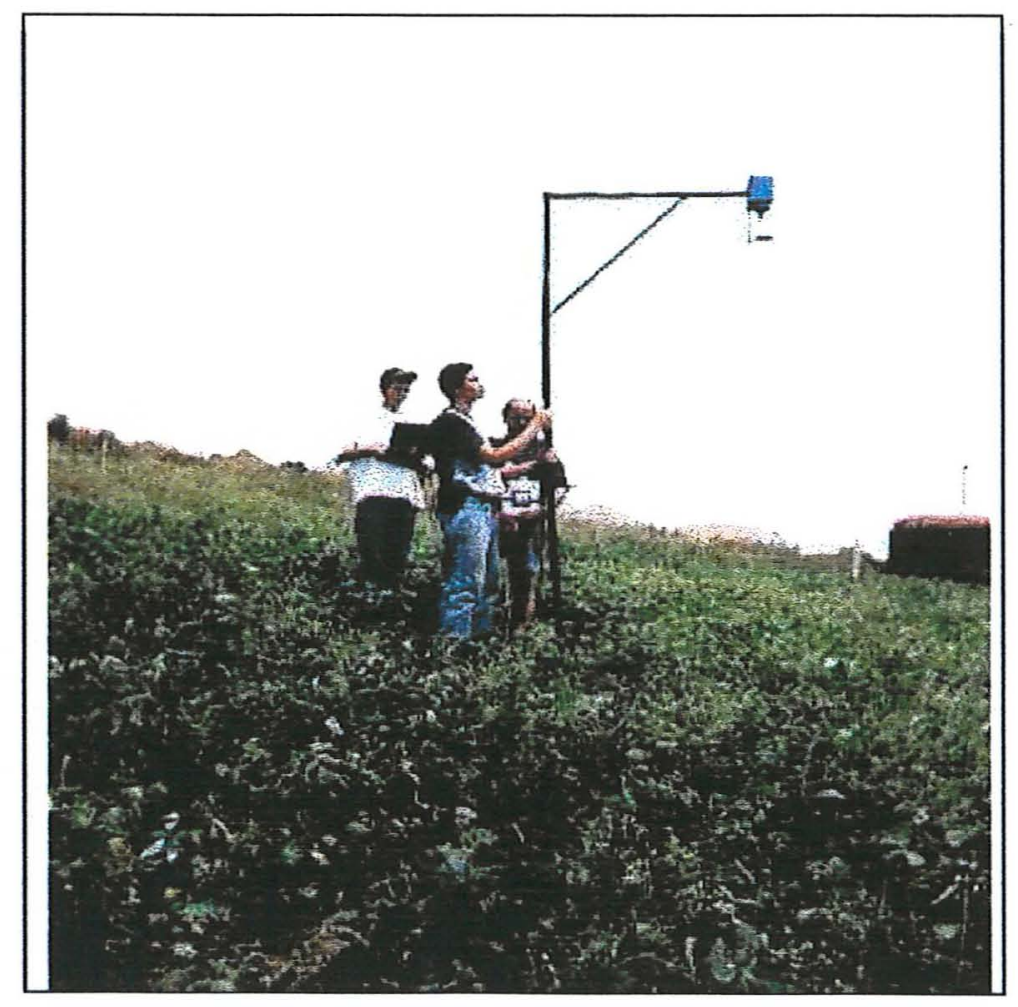

Figura 15 - Tomada de dados radiométricos no campo. 
Após a realização de cada campanha radiométrica, a qual constitui da medição das 24 parcelas, com 2 amostras por parcela, os dados gravados na fita cassete foram transferidos para um microprocessador, através da interface serial RS-232C, utilizandose para isso o programa "ESPECTRO", e tendo como objetivo a transferência e a manipulação dos dados coletados pelo SPECTRON SE-590. Assim sendo, depois da criação do arquivo correspondente a campanha realizada, a cada dado radiométrico transferido da fita para o computador, foi sendo criado pelo programa o espectro correspondente (registro).

Assim, como foram realizadas em cada uma das 24 parcelas um total de 3 leituras, sendo que uma delas correspondente a leitura da cabeça sensora de $6^{\circ}$ na placa de referência e as outras duas leituras referentes a cabeça sensora de $15^{\circ}$ no dossel em questão (alvo), obteve-se ao final do processo de transferência, um total de 72 espectros (correspondentes as leituras nas parcelas) e também mais dois espectros correspondentes as leituras da placa de referência nas duas cabeças sensoras, perfazendo assim um total de 74 espectros para cada uma das campanhas realizadas.

\subsubsection{Cálculo do fator de reflectância (FR)}

Após a transferência de todos os espectros obtidos no campo e utilizando-se ainda do programa "ESPECTRO", calculou-se então o fator de reflectância (FR) médio, representativo de cada uma das parcelas, bem como a simulação posterior desses fatores se relativos às duas bandas do sensor $\mathrm{TM}$ do Landsat $\left(\mathrm{TM}_{3}\right.$ e $\left.\mathrm{TM}_{4}\right)$. Para isso foi empregado o seguinte procedimento:

1)- Calibração dos dados: esta opção permitiu calibrar os espectros referentes ao alvo com aqueles obtidos na placa de referência, por meio da divisão da medida da radiância obtida sobre o dossel do feijão (alvo), pela medida da radiância na placa de referência, obtendo-se assim o fator de reflectância (FR) de cada ponto amostral, como pode ser visto na Equação 9. 


$$
R\left(\theta_{\mathrm{i}}, \varphi_{\mathrm{i}} ; \theta_{\mathrm{r}}, \varphi_{\mathrm{r}} \lambda\right)=\frac{\mathrm{dL}_{\mathrm{a}}\left(\theta_{\mathrm{r}}, \varphi_{\mathrm{r}} \lambda\right)}{\mathrm{dL}_{\mathrm{p}}\left(\theta_{\mathrm{i}}, \varphi_{\mathrm{i}} \lambda\right)} \times \mathrm{k}\left(\theta_{\mathrm{i}}, \varphi_{\mathrm{i}} ; \theta_{\mathrm{r}}, \varphi_{\mathrm{r}} \lambda\right)
$$

em que: $R\left(\theta_{i}, \varphi_{i} ; \theta_{r}, \varphi_{r} \lambda\right)$ é o fator de reflectância bidirecional espectral, $d_{L}\left(\theta_{r}, \varphi_{r} \lambda\right)$ é a radiância espectral do alvo, $\mathrm{dL}_{\mathrm{p}}\left(\theta_{\mathrm{i}}, \varphi_{\mathrm{i}} \lambda\right)$ é a radiância espectral da placa de referência e, $\mathrm{k}\left(\theta_{\mathrm{i}}, \varphi_{\mathrm{i}}, \theta_{\mathrm{r}}, \varphi_{\mathrm{r}} \lambda\right)$ o fator de calibração da placa de referência.

Como foram feitas duas leituras do alvo em cada uma das 24 parcelas, obtivemos ao final um total de 48 espectros calibrados e referentes às leituras dos alvos nas parcelas. Foi feita também a divisão de placa por placa com a finalidade de corrigir a diferença de sensibilidade existente nos dois sensores, obtendo-se assim um outro espectro; esta razão das radiâncias medidas com as duas cabeças sensoras no início da cada campanha radiométrica, é denominada de fator $\mathrm{K}_{\mathrm{i}}$, como mostra a Equação 10 . Assim sendo, ao final de todo o processo de calibração, um total de 49 espectros foram obtidos.

$$
K_{i}=\frac{L_{p 1}(\lambda)}{L_{p 2}(\lambda)}
$$

em que: $K_{i}$ é o fator de intercalibração entre as duas cabeças sensoras, $L_{p 1}(\lambda)$ é a radiância da placa de referência medida no sensor $1\left(\mathrm{~W} \mathrm{~m}^{-2} \mathrm{sr}^{-1}\right)$ e, $\mathrm{L}_{\mathrm{p} 2}(\lambda)$ a radiância da placa de referência medida no sensor $2\left(\mathrm{~W} \mathrm{~m}^{-2} \mathrm{sr}^{-1}\right)$.

2)- Intercalibração: após a calibração, foi feita a intercalibração, para corrigir a diferença de sensibilidade entre os dois sensores nos dados já calibrados. Para tal, dividiu-se o fator reflectância calibrado anteriormente pelo fator $\mathrm{Ki}$. Ao final do processo de intercalibração, permaneceram um total de 48 espectros intercalibrados.

3)- Fator de reflectância médio: feita a intercalibração, havia ainda dois espectros representativos de cada parcela. Com o intuito de se obter um único espectro que 
represente perfeitamente a medida da referida parcela, se tornou necessária a obtenção da média das medidas da reflectância realizadas nessa parcela, obtendo-se assim uma única curva espectral do fator de reflectância da parcela e com valores situados entre 400 a $1100 \mathrm{~nm}$.

4)- Simulação das bandas $\mathrm{TM}_{3}$ e $\mathrm{TM}_{4}$ do Landsat : em seguida, tornou-se necessário simular as bandas do vermelho e do infravermelho próximo, presentes no sensor TM do Landsat, por meio de uma das opções existentes no programa "ESPECTRO". Assim, a partir do fator de reflectância médio de cada parcela obtido anteriormente, foram calculados os valores do FR relativos às duas bandas do sensor TM do Landsat (TM, 630 a $700 \mathrm{~nm} \mathrm{e} \mathrm{TM}_{4}, 760$ a $900 \mathrm{~nm}$ ), com o objetivo de se determinar posteriormente o valor do Índice de Vegetação Diferença Normalizada (NDVI).

\subsubsection{Cálculo do índice de vegetação diferença normalizada (NDVI)}

Após obter os valores de FR relativos as bandas $\mathrm{TM}_{3}$ e $\mathrm{TM}_{4}$ do sensor $\mathrm{TM}$ do Landsat, foi determinado o valor do índice de vegetação diferença normalizado (NDVI), que é um índice com significado físico e usado para caracterizar e quantificar parâmetros biofísicos da vegetação, tais como a radiação fotossinteticamente ativa absorvida (APAR). No presente experimento, os valores encontrados para o NDVI (Anexo C), foram utilizados para a estimativa da radiação fotossinteticamente ativa absorvida pelo dossel da cultura do feijão (APAR). O NDVI foi definido no presente experimento através da expressão (Eq.11) :

$$
\mathrm{NDVI}=\frac{\left(\mathrm{TM}_{4}-\mathrm{TM}_{3}\right)}{\left(\mathrm{TM}_{4}+\mathrm{TM}_{3}\right)}
$$

em que: $\mathrm{TM}_{4}$ é o fator de reflectância medida na faixa espectral do infravermelho próximo (760 a $900 \mathrm{~nm})$ e, $\mathrm{TM}_{3}$ é o fator de reflectância medida na faixa espectral do vermelho $(630$ a $700 \mathrm{~nm})$. 


\subsubsection{Estimativa da radiação fotossinteticamente ativa absorvida ( APAR)}

Após o cálculo do NDVI, procedeu-se a estimativa da radiação fotossinteticamente ativa absorvida pelo dossel da cultura do feijão (APAR), que é a soma algébrica de toda a radiação fotossinteticamente ativa (PAR). A radiação PAR representa a quantidade de radiação solar potencialmente disponível para os processos fotossintéticos e para o consumo da planta; corresponde à radiação solar na faixa de comprimento de onda entre $400 \mathrm{~nm}$ e $700 \mathrm{~nm}$ (visível).

Vários estudos mostram que em plantas sadias e adequadamente supridas de água e nutrientes, existe uma relação linear entre a produção de fitomassa, bem como produção de grãos e a quantidade da PAR absorvida pelo dossel (Gallo et al., 1985; entre outros).

O procedimento utilizado neste trabalho para o cálculo da APAR (radiação fotossinteticamente ativa absorvida), foi o seguinte:

(a) Estimativa de uma fração da radiação fotossinteticamente ativa absorvida $\left(f_{A}\right)$ pelo dossel da cultura do feijão: através de equação empírica proposta por Daughtry et al. (1992), com base no valor do NDVI (Equação 12 ).

$$
f_{\mathrm{A}}=-0,205+1,254 \mathrm{NDVI}
$$

em que: $f_{\mathrm{A}}$ é a fração da radiação fotossinteticamente ativa absorvida e, NDVI é o índice de vegetação com diferença normalizada.

(b) Estimativa da PAR diária: estimativa da radiação fotossinteticamente ativa (PAR) incidente na região de Piracicaba e proximidades durante o período do experimento (julho a outubro de 1999), estimada em função da radiação solar global (Rg) incidente e da razão da insolação (r), razão esta que foi obtida segundo a Equação 13. 


$$
\mathrm{r}=\mathrm{n} / \mathrm{N}
$$

em que: $\mathrm{r}$ é a razão da insolação, $\mathrm{n}$ é o numero de horas de brilho solar diário e, $\mathrm{N}$ é o número de horas possível de brilho solar.

Os respectivos valores usados no presente trabalho, foram obtidos do Posto Agrometeorológico pertencente ao Departamento de Ciências Exatas da ESALQ/ USP (Anexo A).

As estimativas da PAR diária foram feitas segundo as equações de regressão propostas por Assunção (1994), para a respectiva região. Essas estimativas são apresentadas a seguir $\left(\mathrm{MJ} \mathrm{m}^{-2} \mathrm{~d}^{-1}\right)$ :

I) $\mathrm{PAR}=0,417 \mathrm{Rg}$, para dias em que: $\mathrm{r} \leq 0,1 \quad\left(\mathrm{R}^{2}=0,990\right)$

II) $\operatorname{PAR}=0,429 \mathrm{Rg}$ para dias em que: $0,1 \leq \mathrm{r} \leq 0,9 \quad\left(\mathrm{R}^{2}=0,965\right)$

III) PAR $=0,496 \mathrm{Rg}$, para dias em que: $r \geq 0,9 \quad\left(\mathrm{R}^{2}=0,990\right)$

(c) Estimativa da APAR diária - (radiação fotossinteticamente ativa absorvida diária): após a estimativa da fração da radiação fotossinteticamente ativa absorvida $\left(f_{\mathrm{A}}\right)$ pelo dossel da cultura do feijão, e após a estimativa da PAR diária (radiação fotossinteticamente ativa diária) por intermédio de equações de regressão proposta por Assunção (1994) e como já descrito nos itens (a) e (b), procedeu-se a estimativa da APAR diária, isto é, a quantidade da PAR absorvida pelo dossel da cultura do feijão durante cada dia do seu ciclo $\left(\mathrm{MJ} \mathrm{m}^{-2}\right)$. Para isso foi empregada a Equação 17 , como vista a seguir :

$$
\mathrm{APAR}=f_{\mathrm{A}} \times \mathrm{PAR}
$$


em que: $f_{\mathrm{A}}$ é a fração da radiação fotossinteticamente ativa absorvida e estimada através de equação empírica definida e, PAR é a radiação fotossinteticamente ativa diária estimada através de equações de regressão propostas por Assunção (1994), (MJ m ${ }^{-2} \mathrm{~d}^{-1}$ ).

(d) Estimativa da APAR acumulada $\left(\mathrm{APAR}_{\mathrm{ac}}\right)$ durante todo o ciclo da cultura do feijão: após a determinação da APAR diária, calculou-se a APAR acumulada durante o ciclo da cultura, isto é, da germinação até a maturidade fisiológica (Anexo E). Essa estimativa foi obtida pelo somatório da APAR diária e expressa pela seguinte expressão:

$$
\mathrm{APAR}_{\mathrm{ac}}=\Sigma\left(f_{\mathrm{A}} \times \mathrm{PAR}\right)
$$

em que: APAR $_{\text {ac }}$ é a APAR acumulada durante todo o ciclo $\left(\mathrm{MJ} \mathrm{m}^{-2}\right)$ e, $f_{\mathrm{A}} \times$ PAR é considerada como sendo a APAR diária $\left(\mathrm{MJ} \mathrm{m}^{-2}\right)$.

\subsubsection{Cálculo do uso eficiente da radiação}

Segundo Moreira (1997), a eficiência fotoquímica ou uso eficiente da radiação (ع), é resultante do quociente entre a matéria seca (fitomassa ou grão) pela $\operatorname{APAR}_{\mathrm{ac}}$ (APAR acumulada da emergência até a maturidade fisiológica da cultura). Neste trabalho foi calculada a eficiência do uso da radiação para a produção de grãos $\left(\varepsilon_{\mathrm{G}}\right)$, e segundo a seguinte equação (Eq.19):

$$
\varepsilon_{\mathrm{G}}=\text { Produção de grãos }(\mathrm{g}) / \operatorname{APAR}_{\mathrm{ac}}\left(\mathrm{MJ}^{-1}\right)
$$

em que: $\varepsilon_{G}$ é a eficiência fotoquímica calculada para a produção de grãos $\left(\mathrm{g} \mathrm{MJ}^{-1}\right)$.

Moreira (1997), cita ainda que é importante conhecer os valores dessa eficiência para cada tipo de cultura e sua variação em relação aos fatores ambientais, culturais e de manejo, pois ela é uma das variáveis de muitos modelos de crescimento e 
produção de culturas agrícolas, os quais levam em consideração a radiação incidente total, a PAR incidente, a fração PAR absorvida ou interceptada pelo dossel e a eficiência média do uso da radiação num determinado intervalo de tempo.

\subsubsection{Produção e componentes de produção}

Com a finalidade de se estudar o efeito dos níveis de irrigação sobre a produção e sobre alguns componentes de produção, determinou-se por ocasião da colheita os seguintes fatores de cada parcela (Anexo E): a) produtividade de grãos (kg/ha); b) altura

da planta; c) número de vagens por planta; d) comprimento das vagens e; e) número de grãos por vagem. Para a obtenção dos parâmetros acima citados, adotou-se o seguinte procedimento:

a) Produtividade de grãos por hectare: os grãos colhidos na área útil de cada parcela $\left(10,24 \mathrm{~m}^{2}\right)$ foram pesados em balança de precisão de $0,001 \mathrm{~kg}$. Os dados foram a seguir transformados em $\mathrm{kg} / \mathrm{ha}$ e corrigidos para $12 \%$ de umidade, segundo a metodologia indicada por Azevedo (1984).

b) Altura da planta: foi medida a altura de 10 plantas na área útil de cada parcela no momento da colheita. Considerou-se como referência o nível do solo e mediu-se a altura até a inserção do último nó superior da planta. As medidas foram tomadas nas 2 linhas centrais da parcela e em 5 pontos escolhidos ao acaso por linha, medindo-se assim 1 planta por ponto e obtendo-se ao final do processo a altura de 10 plantas, conforme a metodologia proposta pela EMBRAPA (1976).

c) Número de vagens por planta: foram contadas após a colheita, as vagens de 5 plantas de cada uma das parcelas, plantas estas tomadas ao acaso e segundo a metodologia adotada por Loureiro et al. (1990).

d) Comprimento das vagens: foram medidas após a colheita, 10 vagens colhidas ao acaso em cada uma das parcelas, as quais foram retiradas de 5 plantas também escolhidas ao acaso e cujas vagens foram destacadas e misturadas para este fim, segundo a metodologia recomendada pela EMBRAPA (1976). 
e) Número de grãos por vagem: foram contados após a colheita, os grãos de 10 vagens colhidas ao acaso nas plantas de cada parcela. Para o cálculo deste fator, usou-se a metodologia empregada por Loureiro et al. (1990), sendo que as vagens que forneceram os grãos eram as mesmas usadas na avaliação do parâmetro denominado comprimento das vagens.

Como observação, pode-se ainda citar que o teor de umidade de grãos, foi determinado através de amostras com 90 gramas cada e com o auxílio de uma estufa a $105^{\circ} \mathrm{C}$ e durante 24 horas.

O teor de umidade dos grãos foi calculado através da expressão (Eq.20):

$$
U=\frac{P u-P s}{P u} \times 100
$$

em que:

U é a umidade percentual com base no peso úmido (\%),

$\mathrm{Pu}$ é o peso úmido da amostra $(\mathrm{g})$,

Ps é o peso seco da amostra $(\mathrm{g})$.

Para efetuar a correção de umidade dos grãos e vagens para $12 \%$, a fim de se permitir uma maior uniformidade aos dados de produção e seus componentes, utilizouse a seguinte equação recomendada por Azevedo (1984) e dada a seguir (Eq.21):

$$
P_{12}=\frac{P c(1-U a)}{(1-U c)}
$$

em que: $P_{12}=$ peso dos grãos com $12 \%$ de umidade (base no peso úmido), Pc é o peso de campo observado (g), Ua é a umidade observada com base no peso úmido e, Uc é a umidade dos grãos com base no peso úmido após a correção. 


\subsubsection{Análise estatística}

Os resultados obtidos para a radiação fotossinteticamente ativa absorvida acumulada (APAR $\left.{ }_{a c}\right)$, para a eficiência do uso da radiação para a produção de grãos $\left(\varepsilon_{G}\right)$ e para as variáveis agronômicas, foram submetidos à uma análise de variância (ANOVA) utilizando-se para isso o teste $F$ e os níveis de significância de 1 e $5 \%$. As hipóteses testadas para cada uma das variáveis foram:

Hipótese da nulidade $\left(\mathrm{H}_{0}\right)$; Hipótese alternativa $\left(\mathrm{H}_{\mathrm{a}}\right)$

$H_{0}: t_{i}=0$, para todo $i$ (tratamentos não diferem entre si)

$H_{\mathbf{a}}: t_{\mathbf{i}} \neq 0$

em que: $\mathrm{H}_{0}$ é a hipótese da nulidade, $\mathrm{H}_{\mathrm{a}}$ é a hipótese alternativa e, $\mathrm{t}_{\mathrm{i}}$ corresponde as médias dos tratamentos.

As expressões necessárias e usadas para testar $\mathbf{H}_{0}$ são apresentadas no quadro a seguir (Quadro 1):

Quadro 1 - Análise de variância com aplicação do teste F.

\begin{tabular}{lcccc}
\hline Causas de Variação & G.L. & S.Q. & Q.M. & F. \\
\hline Tratamento & 3 & SQtratamento & SQtrat/3 & QMtrat / QMres \\
Resíduo & 20 & SQresiduo & SQres/20 & \\
\hline Total & 23 & SQtotal & & \\
\hline
\end{tabular}

Rejeita-se a hipótese de nulidade $\left(\mathrm{H}_{0}\right)$ se $\mathrm{F}_{\text {calculado }}>\mathrm{F}_{\text {tabelado }}$.

Sempre que o valor de $\mathrm{F}$ encontrado foi significativo ao nível de probabilidade de $1 \%$; isto é, rejeitou-se $\mathrm{H}_{0}$ (hipótese de nulidade) ao nível de $1 \%$ de probabilidade, ou seja, estatisticamente pelo menos 2 tratamentos diferiam entre si a este nível de 
probabilidade, procedeu-se então à análise da diferença entre as médias dos tratamento pelo teste de Tukey, teste este considerado exato e indicado para este tipo de análise.

Através do teste de Tukey, tornou-se possível comparar as médias encontradas e de todos os modos possíveis, como também obter os intervalos de confiança para a diferença entre duas médias. Assim sendo, procedeu-se ao cálculo da diferença mínima significativa (d.m.s.) pela amplitude total estudentizada, e cuja equação é apresentada a seguir (Eq.22).

$$
\text { d.m.s. }=q \frac{s}{\sqrt{r}}
$$

em que:

d.m.s. é a diferença mínima significatica calculada pela prova de Tukey,

$q$ é a amplitude total estudentizada ao nível de $5 \%$ de probabilidade,

$\mathrm{s}$ é a estimativa do desvio padrão,

r é o número de repetições de cada um dos tratamentos.

Todas as análises estatísticas foram ainda realizadas usando o pacote estatístico denominado “ Statistical Analysis System “ (SAS Institute, 1985). 


\section{RESULTADOS E DISCUSSÃO}

4.1. Análise do fator de reflectância das bandas $\mathbf{T M}_{3}$ e $T M_{4}$ e do índice de vegetação diferença normalizada (NDVI) .

$\mathrm{O}$ comportamento observado do fator de reflectância (FR) nas bandas $\mathrm{TM}_{3} \mathrm{e}$ $\mathrm{TM}_{4}$ ao longo do desenvolvimento da cultura, e tendo em vista os quatro tratamentos utilizados, são apresentados através das respectivas curvas de tendência nas Figuras 16 e 17 , e discutidos a seguir.

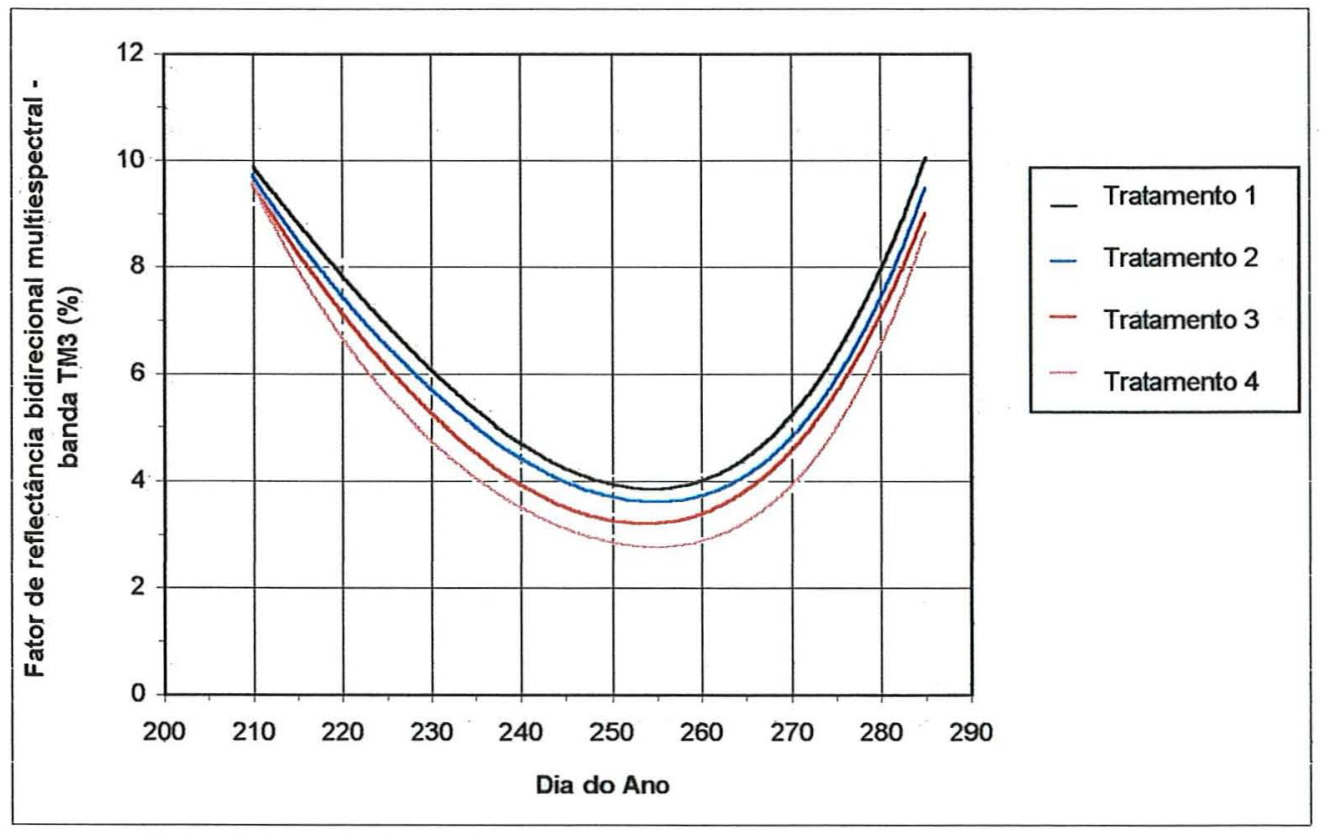

Figura 16 - Fator de reflectância na banda $\mathrm{TM}_{3}$, obtido ao longo do ciclo da cultura do feijão, para os diferentes tratamentos utilizados. 
Observa-se na Figura 16 que os valores do fator de reflectância (FR) na banda $\mathrm{TM}_{3}$ e para os diferentes tratamentos, apresentaram um comportamento semelhante entre si, assemelhando-se a uma "parábola invertida". De uma forma geral observa-se que no início da cultura em função da baixa porcentagem de cobertura verde e devido ainda a grande influência da reflectância do solo, o fator de reflectância é máximo na banda $\mathrm{TM}_{3}$ e em torno de $9 \%$. A medida que a cultura vai se desenvolvendo, nota-se um aumento da quantidade de fitomassa e do índice de área foliar, o qual proporciona um aumento da quantidade de clorofila nas folhas e consequentemente uma maior absorção de radiação por estas. Assim sendo, em virtude desse fato, observa-se um decréscimo no valor do fator de reflectância, tal como observado por Formaggio (1989). Aumentando a absorção, nota-se então um decréscimo do FR na banda $\mathrm{TM}_{3}$ até próximo de $3 \%$, onde permanece nesse patamar entre os dias julianos 248 a 258 , correspondentes a 52 dias após o plantio ( época correspondente a floração) e 62 dias após o plantio (época de enchimento das vagens de sementes). Após esse período, o qual corresponde ao final do enchimento das vagens e o início da maturação das sementes, o FR aumentou gradativamente até atingir um valor máximo em torno de $10 \%$, valor este encontrado quando a cultura se encontrava próxima do dia juliano 284 ( 88 dias de idade e cerca de $90 \%$ das vagens já maduras). Esse aumento no valor do fator de reflectância (FR) é explicado pela senescência da maioria das folhas, as quais se encontravam amarelecidas devido a degradação das clorofilas. Assim sendo, com a diminuição da clorofila e conseqüente diminuição da absorção da radiação solar pelo dossel da cultura do feijão, observa-se um aumento progressivo do fator de reflectância na banda $\mathrm{TM}_{3}$, o qual também foi influenciado pelo aumento da reflectância do solo, tal qual ocorreu no início do ciclo da cultura.

Verifica-se também que o tratamento 1 (testemunha), devido estar submetido a menor lâmina de água e tendo como resultado um menor desenvolvimento vegetativo e maior influência da exposição do solo, foi o que apresentou os maiores valores do FR na banda $\mathrm{TM}_{3}$, quando comparado com os outros tratamentos. A medida em que as lâminas de água foram acrescidas, houve um maior desenvolvimento vegetativo da cultura, maior índice foliar e menor exposição do solo, com diminuição dos valores do FR na 
banda $\mathrm{TM}_{3}$ (maior absorção). Esse aumento da reflectância na região do visível e no final do ciclo da cultura, está de acordo com o observado por Formaggio (1989) e Moreira (1997).

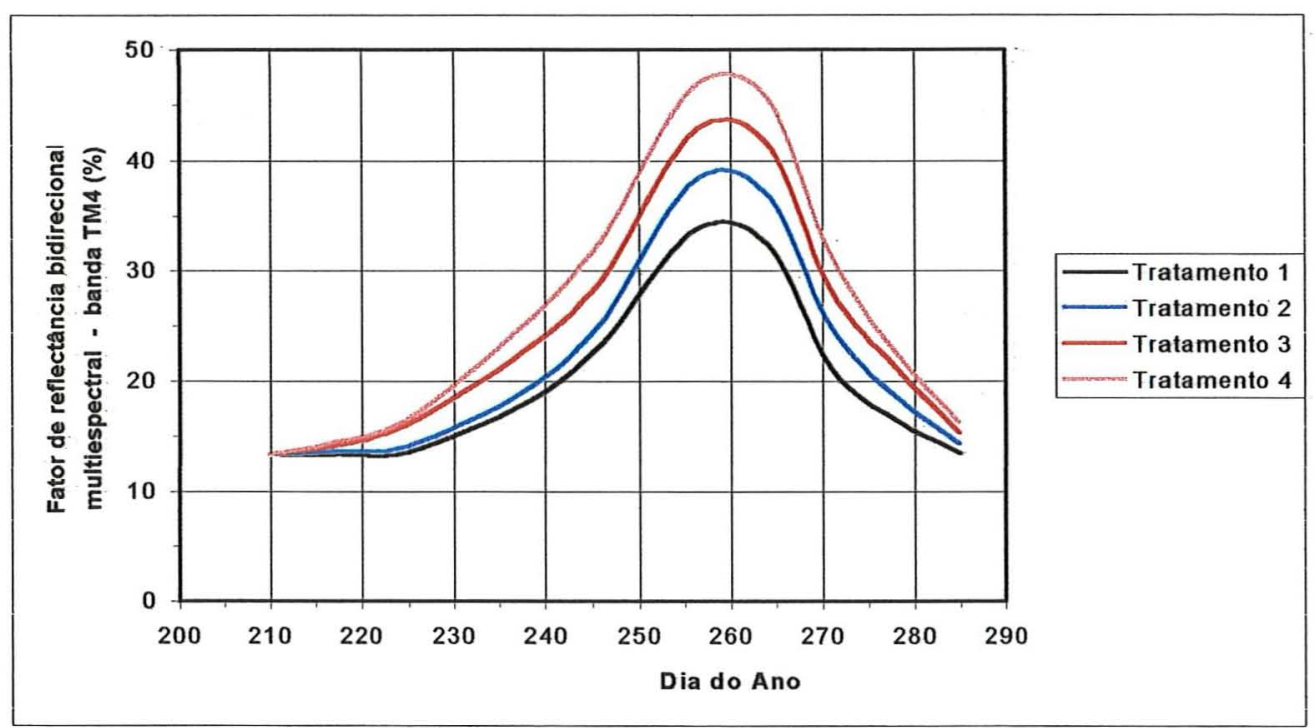

Figura 17 - Fator de reflectância na banda $\mathrm{TM}_{4}$, obtido ao longo do ciclo da cultura do feijão, para os diferentes tratamentos utilizados.

Analisando os valores do fator de reflectância (FR) na banda $\mathrm{TM}_{4}$ e segundo a Figura 17 dada acima, observa-se que para os quatro tratamentos utilizados, o comportamento espectral foi muito parecido entre si durante todo o desenvolvimento da cultura do feijão. As reflectâncias foram maiores à medida em que a quantidade de camadas de folhas foi aumentando, refletindo assim na porcentagem de cobertura vegetal sobre o terreno, o que permitiu um crescimento dos efeitos multiplicativos da reflexão até se atingir um determinado ponto máximo, como observado por Formaggio (1989). O desenvolvimento da cultura do feijão em termos de emissão foliar é lento no início do seu ciclo, e cresce geometricamente a partir das primeiras folhas até o início da maturação; assim sendo, observa-se um constante aumento da quantidade de folhas fotossinteticamente ativas e conseqüente aumento no fator de reflectância na banda $\mathrm{TM}_{4}$. 
É interessante observar que ao aumentar o vigor da vegetação, aumentaram os valores de reflectância na banda $\mathrm{TM}_{4}$, ocorrendo o inverso com os valores de $\mathrm{TM}_{3}$. Porém, a faixa de valores dentro dos quais ocorrem as reflectâncias na banda $\mathrm{TM}_{4}$ (cerca de 13 a $48 \%$ ) é muito mais ampla do que para a banda $\mathrm{TM}_{3}$ (cerca de 3 a 10\%).

A curva espectral (Figura 17), mostra o comportamento espectral da cultura do feijão na banda $\mathrm{TM}_{4}$ para os quatro tratamentos e de forma bastante semelhante verificase a fase de solo praticamente exposto (até cerca do dia 226 do ano, ou 30 dias de idade da cultura), com valores mínimos do FR, passando a seguir por fases intermediárias (solo exposto mais massa verde da cultura) e assumindo finalmente o comportamento espectral típico de vegetação verde vigorosa por volta do dia juliano 234 (38 dias do ciclo a contar da data de plantio), permanecendo nessa tipicidade espectral até por volta do dia do ano $284\left(88^{\circ}\right.$ dia do seu ciclo), isto é, por aproximadamente 50 dias, tal como observado por Formaggio (1989). O valor máximo do fator de reflectância na banda $\mathrm{TM}_{4}$ é notado para os quatro tratamentos por volta do dia juliano 258 (62 dias de idade), época em que a cultura apresentou a máxima absorção da radiação solar na região do vermelho do espectro eletromagnético. A partir dessa fase, observa-se a diminuição do fator de reflectância de forma quase linear e devido ao início da fase de senescência da cultura do feijão, onde ocorre o amarelecimento, secamento e a queda acentuada das folhas, voltando-se por fim no final do ciclo, quando as folhas já secaram e cairam e restando apenas os tecidos de sustentação e as vagens, a expor grande porcentagem do solo e com comportamento espectral semelhante ao início do ciclo.

Analisando os quatro tratamentos de forma particular, pode-se afirmar que todos eles apresentaram um valor máximo do fator de reflectância na banda $\mathrm{TM}_{4}$ aproximadamente no dia 258 (62 dias após o plantio da cultura). 0 tratamento 4 devido ter sido submetido a maior lâmina de água $(373,40 \mathrm{~mm})$, foi o que apresentou o melhor desenvolvimento vegetativo em relação aos demais tratamentos, apresentando assim uma maior produção de fitomassa e maiores valores do fator de reflectância (atingindo um valor máximo próximo de $48 \%$ ). O tratamento 3 , o qual recebeu uma lâmina correspondente a $288,40 \mathrm{~mm}$, apresentou durante todo o ciclo, uma menor quantidade de 
fitomassa do que o tratamento anteriormente descrito e conseqüentemente menores valores do fator de reflectância, atingindo um valor máximo em torno de $43 \%$. Em seguida, observa-se o tratamento 2 , o qual foi submetido a uma lâmina de água correspondente a $206,40 \mathrm{~mm}$ e com um valor do fator de reflectância máximo próximo de $40 \%$. Por fim, observa-se ainda o tratamento 1 (testemunha), submetido a menor lâmina de água e igual a $164,40 \mathrm{~mm}$ no seu ciclo total e, apresentando, o menor valor do fator de reflectância se comparado com os outros tratamentos (cerca de 35\%). Assim, é possível estabelecer que a partir do momento em que a vegetação começou a revelar comportamento espectral típico de vegetação verde vigorosa (dia do ano 234), as maiores lâminas empregadas corresponderam as maiores fitomassas; como conseqüência, maiores valores do fator de reflectância na banda $\mathrm{TM}_{4}$ foram observados.

Os valores dos índices de vegetação diferença normalizada (NDVI), obtidos a partir dos fatores de reflectância nas bandas $\mathrm{TM}_{3}$ e $\mathrm{TM}_{4}$, também foram calculados e graficamente representados, conforme pode ser visto na Figura 18.

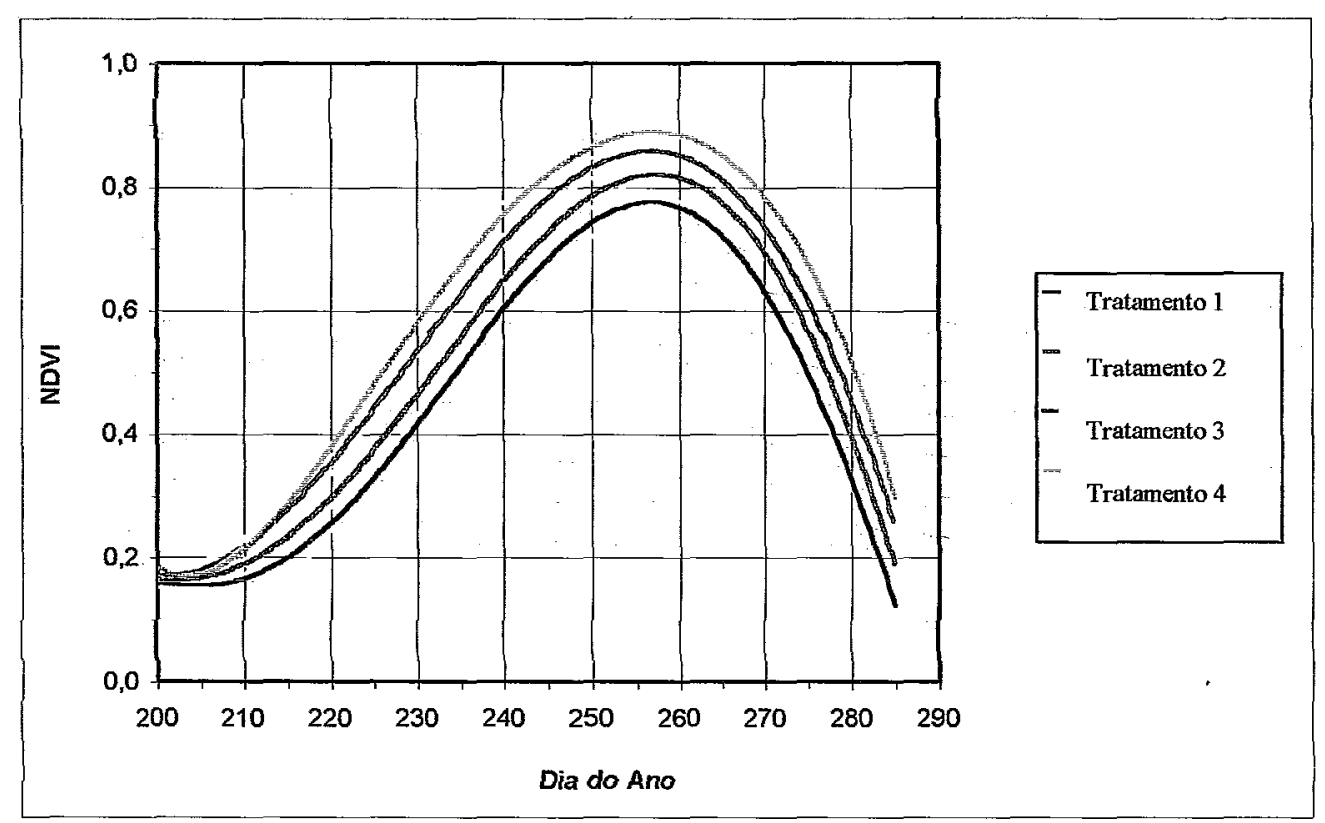

Figura 18 - Índice de vegetação diferença normalizada (NDVI), obtido ao longo do ciclo da cultura do feijã̃o e para os diferentes tratamentos. 
Analisando a trajetória do NDVI na Figura 18, nota-se que independente da lâmina de água a que foi submetida a cultura, o comportamento ao longo do seu ciclo foi semelhante para os quatro tratamentos, ou seja, todos eles apresentaram um mesmo comportamento em forma de parábola, tal qual observado por Formaggio (1989) e Moreira (1997). Os valores correspondentes as fases inicial e final do ciclo da cultura se situaram em torno de 0,2 , sendo que um valor máximo de 0,9 foi observado aproximadamente aos 62 dias após o plantio da cultura (dia juliano 258) e para o tratamento 4 (submetido a maior lâmina de água).

Observa-se na Figura 18, o comportamento parabólico do NDVI ao longo do ciclo do feijão, sendo que há um crescimento constante dos valores até por volta do dia juliano 258 (62 dias do pantio), atingindo-se então um pico, após o que se inicia um decaimento contínuo até o final do ciclo, sendo que os valores voltam então a se situar próximos aos do início.

O mesmo comportamento parabólico é observado quando se analisa o fator de reflectância na banda $\mathrm{TM}_{4}$, podendo-se afirmar que os valores do NDVI estão mais relacionados com as diferenças observadas nos valores do $\mathrm{FR}$ na banda $\mathrm{TM}_{4}$ do que na banda $\mathrm{TM}_{3}$, conforme cita Moreira (1997). Assim sendo, observou-se que quanto maior a lâmina de água a que foi submetido o tratamento, maior foi a fitomassa produzida $\mathrm{e}$ conseqüentemente maior foi o FR na banda $\mathrm{TM}_{4}$; dessa forma, maiores valores máximos do NDVI foram encontrados para as maiores lâminas aplicadas.

Pode-se ainda dizer que o NDVI, por considerar as reflectâncias observadas nas bandas $\mathrm{TM}_{3}$ e $\mathrm{TM}_{4}$ (razão normalizada entre as duas bandas), parece ser um melhor estimador dos efeitos das várias lâminas de água no desenvolvimento e produção de fitomassa na cultura do feijão, do que quando procedemos a análise das bandas individualmente para esse fim. 


\subsection{Estimativa da radiação fotossinteticamente ativa absorvida acumulada, e do uso eficiente da radiação para a produção de grãos.}

Após se obter os valores de FR relativos as bandas $\mathrm{TM}_{3}$ e $\mathrm{TM}_{4}$ do sensor $\mathrm{TM}$ do Landsat, foram determinados os valores do índice de vegetação diferença normalizado (NDVI) relativos ao período correspondente da emergência até a maturidade fisiológica da cultura. Nas datas em que não foram realizadas as campanhas radiométricas, obtevese o NDVI através de interpolação linear dos valores das medidas radiométricas de duas datas adjacentes.

Em seguida, estimou-se a fração da radiação fotossinteticamente ativa absorvida $\left(f_{\mathrm{A}}\right)$ através da Eq.(12), e a PAR diária incidente na região através da Eq.(15). Obtido esses valores, procedeu-se a estimativa da APAR diária através da Eq.(17), para então estimar a radiação fotossintéticamente ativa absorvida acumulada (APAR ${ }_{a c}$ ), através do somatório da APAR diária (Eq.18) e cujos valores médios encontrados para os tratamentos $1,2,3$ e 4 , se encontram na Tabela 10.

Com os valores da $\mathrm{APAR}_{\mathrm{ac}}$ e da produção de grãos referentes a cada um dos 4 tratamentos realizados, determinou-se a eficiência do uso da radiação para a produção de grãos $\left(\varepsilon_{\mathrm{G}}\right)$ através da Eq. (19) e conforme consta na Tabela 12.

Os resultados encontrados e referentes a $\operatorname{APAR}_{a c}$ e a eficiência do uso da radiação para a produção de grãos $\left(\varepsilon_{G}\right)$, foram por fím submetidos a uma análise de variância e sempre que o valor de $\mathrm{F}$ se mostrou significativo, aplicou-se o teste de Tukey.

Para a radiação fotossinteticamente ativa absorvida acumulada $\left(\operatorname{APAR}_{\mathrm{ac}}\right)$, a análise de variância indicou uma diferença estatística entre os tratamentos ao nível de significância de $1 \%$ de probabilidade (Tabela 9). Comparando-se ainda através do teste de Tukey, as médias obtidas da $\mathrm{APAR}_{\mathrm{ac}}$ (Tabela 10), percebe-se que todos os tratamentos diferiram estatisticamente entre si ao nível de $5 \%$ de probabilidade; assim sendo, pode-se inferir que no decorrer do experimento, a $A \mathrm{PAR}_{\mathrm{ac}}$ foi influenciada pelos diferentes tratamentos utilizados. 
Tabela 9 - Resumo da análise de variância da radiação fotossinteticamente ativa absorvida acumulada ( $\mathrm{APAR}_{\mathrm{ac}}$ ).

\begin{tabular}{lcccc}
\hline Causas de Variação & G.L. & S.Q. & Q.M. & F. \\
\hline Tratamentos & 3 & 33737,3636 & 11245,7878 & $221,06^{* *}$ \\
Resíduo & 20 & 1017,4320 & 50,8716 & \\
\hline Total & 23 & 34754,7956 & & \\
\hline
\end{tabular}

C.V. $\%=2,48$

** = significativo ao nível de $1 \%$ de probabilidade.

A seguir (Tabela 10), é apresentado o teste de Tukey, e tendo em vista os resultados da radiação fotossinteticamente ativa absorvida acumulada (APAR $\mathbf{R}_{\mathrm{ac}}$ ).

Tabela 10 - Teste de Tukey para os resultados da média da radiação fotossinteticamente ativa absorvida acumulada $\left(\mathrm{APAR}_{\mathrm{ac}}\right)$.

\begin{tabular}{cccccc}
\hline Ordem & Tratamento & N. Repet. & Média $\left(\mathrm{MJm}^{-2}\right)$ & D.R (\%) & Signif: 5\% \\
\hline 1 & 4 & 6 & 335,689 & 42,08 & $\mathrm{a}$ \\
2 & 3 & 6 & 307,308 & 30,08 & $\mathrm{~b}$ \\
3 & 2 & 6 & 270,704 & 14,58 & $\mathrm{c}$ \\
4 & 1 & 6 & 236,253 & $-\cdots$ & $\mathrm{d}$ \\
\hline
\end{tabular}

Obs.: médias seguidas da mesma letra não diferem entre si estatisticamente pelo teste de Tukey, ao nível de $5 \%$ de probabilidade.

D.R. = diferença relativa à testemunha.

D.M.S. $(5 \%)=11,526$ 
Observando-se as médias de tratamento apresentadas na Tabela 10, nota-se que de maneira geral, a medida em que se diminuíram as lâminas de água aplicadas, reduziuse também a APAR

O maior valor médio da $\mathrm{APAR}_{\mathrm{ac}}$ é observado no tratamento 4, correspondente a maior lâmina total $(373,40 \mathrm{~mm})$ e apresentando um valor igual a $335,689 \mathrm{MJm}^{-2}$. O tratamento 4 , também apresentou a maior diferença percentual significativa relativa à testemunha (tratamento 1) e igual a $42,08 \%$.

$\mathrm{O}$ menor valor médio da $\operatorname{APAR}_{\mathrm{ac}}\left(236,253 \mathrm{MJm}^{-2}\right)$, é notado no tratamento 1 (testemunha), o qual foi submetido a menor lâmina de água $(164,40 \mathrm{~mm})$. Este fato pode também ser associado a observação feita no campo, onde se notou que este tratamento apresentou ao final do experimento, o menor número de plantas por metro quadrado e conseqüente menor absorção da radiação.

Valores intermediários da $\mathrm{APAR}_{\mathrm{ac}}$ são observados para os tratamentos 2 e 3 , sendo que o tratamento 3, o qual foi submetido a uma lâmina de água de $288,40 \mathrm{~mm}$, apresentou um maior valor da $\operatorname{APAR}_{\mathrm{ac}}\left(307,308 \mathrm{MJm}^{-2}\right)$, se comparado com o tratamento $2\left(270,704 \mathrm{MJm}^{-2}\right)$ e submetido a uma lâmina de água igual a 206,40 mm.

Nota-se ainda através da Tabela 10, que os tratamentos 2 e 3, apresentam uma significativa diferença percentual em relação ao tratamento testemunha de $14,58 \% \mathrm{e}$ $30,08 \%$, respectivamente.

Concluindo, pode-se afirmar que diferentes lâminas de água influenciaram significativamente a $5 \%$ de probabilidade a $\mathrm{APAR}_{\mathrm{ac}}$ durante o ciclo da cultura do feijão, e que as maiores lâminas, por apresentarem o maior número de plantas por metro quadrado e consequentemente uma maior absorção da radiação, foram as que corresponderam a maiores valores da $\mathrm{APAR}_{\mathrm{ac}}$. Esta conclusão está de acordo com Gallo et al. (1985) e Asrar (1989).

Analisando os resultados da análise de variância da eficiência do uso da radiação para a produção de grãos $\left(\varepsilon_{G}\right)$, apresentados na Tabela 11 , observa-se a existência de diferença estatística entre os tratamentos ao nível de significância de $1 \%$. 
Tabela 11 - Resumo da análise de variância da eficiência do uso da radiação para a produção de grãos $\left(\varepsilon_{\mathrm{G}}\right)$.

\begin{tabular}{lcccc}
\hline Causas de Variação & G.L. & S.Q. & Q.M. & F. \\
\hline Tratamentos & 3 & 1,11697 & 0,37232 & $3366,37^{* *}$ \\
Resíduo & 20 & 0,00221 & 0,00011 & \\
\hline Total & 23 & 1,11918 & & \\
\hline
\end{tabular}

C.V. $\%=2,35$

** = significativo ao nível de $1 \%$ de probabilidade.

A Tabela 12 apresentada a seguir, apresenta os resultados obtidos para o teste de Tukey, e tendo em vista a variável denominada eficiência do uso da radiação para a produção de grãos $\left(\varepsilon_{G}\right)$.

Tabela 12 - Teste de Tukey para os resultados da eficiência do uso da radiação para a produção de grãos $\left(\varepsilon_{G}\right)$.

\begin{tabular}{cccccc} 
Ordem & Tratamento & N. Repet. & Média $\left(\mathrm{g} \mathrm{MJ}^{-1}\right)$ & D.R (\%) & Signif: 5\% \\
\hline 1 & 4 & 6 & 0,75691 & 232,19 & $\mathrm{a}$ \\
2 & 3 & 6 & 0,53726 & 135,79 & $\mathrm{~b}$ \\
3 & 2 & 6 & 0,26274 & 15,31 & $\mathrm{c}$ \\
4 & 1 & 6 & 0,22785 & $-\cdots$ & $\mathrm{d}$ \\
\hline
\end{tabular}

Obs.: médias seguidas da mesma letra não diferem entre si estatisticamente pelo teste de Tukey, ao nível de $5 \%$ de probabilidade.

D.R. = diferença relativa à testemunha.

D.M.S. $(5 \%)=0,017$ 
Fazendo-se a comparação entre as médias da eficiência do uso da radiação para a produção de grãos $\left(\varepsilon_{G}\right)$ pelo teste de Tukey, contidas na Tabela 12, pode-se afirmar que todos os tratamentos diferiram estatisticamente entre si ao nível de $5 \%$ de probabilidade; dessa forma, é possível concluir que a eficiência do uso da radiação para a produção de grãos $\left(\varepsilon_{\mathrm{G}}\right)$ foi influenciada pelos diferentes tratamentos utilizados.

Observando-se as médias de tratamento apresentadas na Tabela 12, nota-se que a medida em que diminuíram as lâminas de água aplicadas, reduziu-se a $\varepsilon_{\mathrm{G}}$. Nota-se também que os tratamentos 2,3 e 4, apresentam diferença ao nível de significância de $5 \%$ em relação ao tratamento testemunha (tratamento 1 ). Observa-se que o maior valor da eficiência do uso da radiação para a produção de grãos é encontrada no tratamento 4 , correspondente a maior lâmina aplicada e valor de $0,75691 \mathrm{~g} \mathrm{MJ}^{-1}$. Esta ocorrência, pode ser associada ao fato deste tratamento ter apresentado ao final do ciclo, os maiores valores de produtividade de grãos, se comparado com os demais tratamentos. $\mathrm{O}$ tratamento 4 apresenta ainda e segundo a Tabela 12 , a maior diferença percentual significativa relativa à testemunha (tratamento 1), e igual a $232,10 \%$.

O menor valor médio da eficiência do uso da radiação para a produção de grãos $\left(0,22785 \mathrm{~g} \mathrm{MJ}^{1}\right)$ é notado no tratamento 1 (testemunha), o qual por sua vez foi aquele submetido a menor lâmina de água $(164,40 \mathrm{~mm})$ e também apresentou os menores valores finais de produtividade de grãos, se comparado com os demais tratamentos.

Nota-se também pela Tabela 12, que o tratamento 3, o qual foi submetido a uma lâmina de água de $288,40 \mathrm{~mm}$, apresentou um maior valor da $\varepsilon_{\mathrm{G}}\left(0,53726 \mathrm{~g} \mathrm{MJ}^{1}\right)$, se comparado com o tratamento $2\left(0,26274 \mathrm{~g} \mathrm{MJ}^{-1}\right)$, o qual foi submetido a uma lâmina de água menor e igual a $206,40 \mathrm{~mm}$.

Por fim, pode-se concluir que, diferentes lâminas de água influenciaram significativamente a $5 \%$ de probabilidade a eficiência do uso da radiação para a produção de grãos, e que foram as maiores lâminas que corresponderam aos maiores valores observados, concordando com Rawson et al. (1984) e Squire et al. (1984). 


\subsection{Análise da produção e dos componentes de produção}

Na Tabela 13 estão contidos os resultados referentes a análise de variância para as médias relacionadas a produção e aos componentes de produção, considerando a cultura do feijão e tendo em vista os diferentes tratamentos empregados (lâminas de água). Assim sendo, são apresentados os valores médios obtidos no experimento, em relação a produtividade de grãos ( $\mathrm{kg} / \mathrm{ha})$, altura da planta, número de vagens por planta, comprimento das vagens e número de grãos por vagem, para cada tratamento.

Observa-se assim, os tratamentos 1,2,3 e 4, os quais correspondem as lâminas totais aplicadas de $164,40 \mathrm{~mm} ; 206,40 \mathrm{~mm} ; 288,40 \mathrm{~mm}$ e $373,40 \mathrm{~mm}$ respectivamente, valores estes resultado da somatória das aplicações realizadas com o sistema de aspersão em linha, chuvas e irrigações uniformes no estágio inicial da cultura.

De acordo com os resultados estatísticos contidos na Tabela 13, pode-se afirmar que diferentes lâminas de água influenciaram significativamente com diferentes intensidades, cada uma das variáveis agronômicas analisadas, sendo que o tratamento 4 correspondente a maior lâmina total $(373,40 \mathrm{~mm})$, foi o que propiciou os melhores resultados em todos os componentes estudados.

Nota-se também, um efeito significativo com o aumento das lâminas totais de água sobre a variável produtividade de grãos e a totalidade dos componentes de produção analisados, tais como: altura da planta, número de vagens por planta, comprimento das vagens e número de grãos por vagem.

Verifica-se através da Tabela 13, que a irrigação possibilitou um aumento de cerca de $372 \%$ na produtividade de grãos em relação à testemunha, revelando o efeito altamente positivo dos tratamentos de irrigação na produção. As maiores produtividades variaram de $1650,83 \mathrm{~kg} / \mathrm{ha}$ (tratamento 3) a $2540,00 \mathrm{~kg} / \mathrm{ha}$ (tratamento 4) e foram observadas ao nível situado entre $288,40 \mathrm{~mm}$ e $373,40 \mathrm{~mm}$ de lâmina total. 


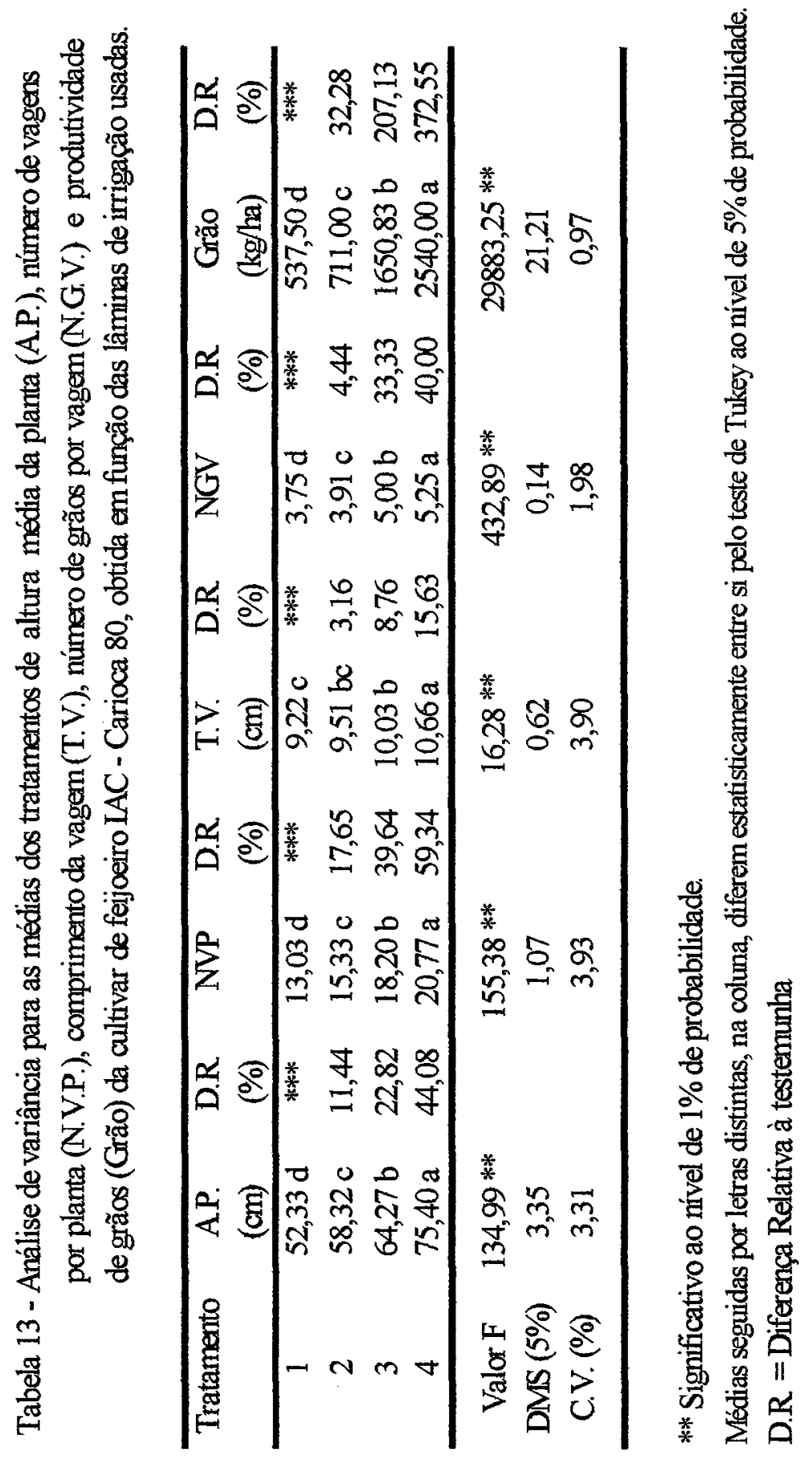


Por sua vez, nota-se também que esses dois tratamentos apresentaram um diferença percentual bastante significativa de 372\% (tratamento 4) e $207 \%$ (tratamento 3) na média de produtividade de grãos e em relação à testemunha $(p<0,05)$.

As menores lâminas correspondentes aos tratamentos 1(testemunha) e 2, e equivalentes a $164,40 \mathrm{~mm}$ e $206,40 \mathrm{~mm}$ de lâmina total, foram as que propiciaram as menores produtividade de grãos e iguais a $537,50 \mathrm{~kg} / \mathrm{ha}$ e $711,00 \mathrm{~kg} / \mathrm{ha}$. Comportamento semelhante foi encontrado por Mack \& Bonanno (1981), Azevedo (1984), Silveira et al. (1984), Frizzone (1986), Fancelli (1987), Loureiro et al. (1990), Libardi et al. (1994) e Paz et al. (1997). As variáveis que mais influenciaram o incremento de produtividade no respectivo experimento, podem ser definidas como o número de vagens por planta e o número de sementes por vagem, variáveis estas que apresentaram valores crescentes a medida em que as lâminas totais de água foram acrescidas, e tal qual observado por Turner \& Begg (1981), Costa (1987), Moreira et al. (1996) e Paz et al. (1997).

Com relação ao componente altura média da planta, a análise de variância indica uma diferença estatística entre os tratamentos ao nível de significância de $1 \%$ e pelo teste de Tukey, pode-se concluir que todos os tratamentos diferem entre si ao nível de $5 \%$ de probabilidade. Através da Tabela 13, constata-se que houve uma diferença de altura igual a $44,08 \%$ do tratamento submetido a maior lâmina total de água (tratamento 4) em relação a testemunha (tratamento 1) e de $22,82 \%$ do tratamento 3 em relação a mesma testemunha $(p<0,05)$. $O$ tratamento 2 apresentou a menor variação percentual $\mathrm{e}$ correspondente a $11,44 \%$, dentre todos analisados. Dessa forma, pode-se concluir que os tratamentos mais úmidos apresentaram maior altura de plantas no final do experimento, demonstrando assim o efeito significativo da umidade no crescimento em altura para o feijão. Essa constatação está de acordo com Loureiro et al. (1990), os quais definem que a lâmina de água de irrigação apresenta efeito significativo sobre a altura da planta do feijão.

Quanto ao número de vagens por planta, nota-se através da análise de variância desse fator, presente na Tabela 13, que ocorreu um efeito significativo da lâmina de água sobre esse componente de produção. Assim sendo, o tratamento 4 e correspondente a 
maior lâmina irrigada, apresentou também o maior acréscimo percentual correspondente a 59,34\% e em relação à testemunha. Os tratamentos 3 e 2 , e correspondentes as lâminas de $288,40 \mathrm{~mm}$ e $206,40 \mathrm{~mm}$, revelaram incrementos percentuais de $39,64 \%$ e $17,65 \%$, em relação à mesma testemunha $(p<0,05)$, indicando por fim que diferentes lâminas de água influenciaram de forma significativa o número de vagens por planta no presente experimento, tal como descrito por Paz et al. (1990), ao concluirem que o número de vagens por planta é um dos parâmetros que apresenta maior sensibilidade aos diferentes níveis de disponibilidade de água. Essa observação está também de acordo com Mack \& Bonanno (1981) e Loureiro et al. (1990), os quais afirmam que qualquer deficiência hídrica nas fases críticas de florescimento e formação dos grãos, compromete em muito o rendimento produtivo da cultura e principalmente devido à redução do número de vagens por planta.

Com relação ao comprimento das vagens, a análise de variância contida na Tabela 13, indica uma diferença estatística entre os tratamentos ao nível de significância de $1 \%$ e pelo teste de Tukey, percebe-se que os tratamentos 2 e 3 são estatisticamente semelhantes entre si, o mesmo ocorrendo entre os tratamentos 1 e 2 , os quais não diferem estatisticamente entre si ao nível de $5 \%$ de probabilidade. Observa-se ainda pela mesma tabela, que ocorreu um pequeno incremento percentual relativo as médias, a medida que maiores lâminas foram aplicadas. Assim sendo, os maiores tamanhos médios das vagens foram observados no tratamento 4 , o qual representa a maior lâmina de água empregada e com um incremento percentual significativo de $15,63 \%$, quando comparado com o tratamento testemunha $(p<0,05)$. Em seguida, nota-se o tratamento 3 com um incremento significativo de $8,76 \%$ em relação a mesma testemunha $(p<0,05)$ e não diferindo estatisticamente ao nível de $5 \%$ de probabilidade do tratamento 2 , o qual por sua vez apresentou uma variação percentual igual a $3,16 \%$ em relação ao tratamento testemunha, e não diferindo deste em termos estatísticos. Conclui-se por fim, ao se analisar as médias relativas ao parâmetro comprimento das vagens e as respectivas análises estatísticas, que apenas os tratamentos $3(288,40 \mathrm{~mm})$ e $4(373,40 \mathrm{~mm})$ foram afetados significativamente pelas lâminas de água, em relação ao tratamento testemunha $(p<0,05)$. Comportamento semelhante foi observado por Cardoso et al. (1997). 
Para o componente de produção número de grãos por vagem, a análise de variância indica uma diferença estatística entre os tratamentos ao nível de significância de $1 \%$ e pelo teste de Tukey, pode-se concluir que todos os tratamentos diferem entre si ao nível de $5 \%$ de probabilidade. Para este componente, as médias observadas, mostram valores que podem ser considerados significativos para os tratamentos de irrigação utilizados, notando-se assim um acréscimo percentual do número de grãos por vagem em relação à testemunha, a medida em que as lâminas foram acrescidas. As médias apresentadas na Tabela 13, mostram maior número de grãos por vagem no tratamento mais irrigado (tratamento 4), o qual difere em 40,00\% do tratamento testemunha (tratamento 1$)(p<0,05)$. Percebe-se a seguir o tratamento 3 , com um acréscimo percentual em torno de $33,33 \%$ em relação à testemunha e variando cerca de $7 \%$ do tratamento 4, não havendo assim diferença percentual acentuada entre esses dois tratamentos. Por fim, observa-se o tratamento 2 , o qual pouco difere do tratamento 1 (testemunha) na análise percentual, e apresentando um pequeno incremento de 4,44\% em relação a este, apesar de diferirem estatisticamente entre si ao nível de $5 \%$ de probabilidade.

A tendência estabelecida no experimento, de um acréscimo do número de grãos por vagem e por efeito do incremento da lâmina total, foi também percebida e relatada por Azevedo (1984) e por Moreira et al. (1996), sendo que os últimos afirmam que o número de sementes por vagem é o componente do rendimento de grãos do feijão mais afetado pelo tamanho da lâmina de água e, principalmente, quando se considera $o$ período reprodutivo da cultura; assim sendo, a ocorrência de deficiência hídrica durante esse período irá provocar uma alta percentagem de abcisão das flores e abortamento de óvulos, reduzindo assim o número de grãos por vagem da cultura.

Como observação, pode-se citar que foi também avaliado o peso da matéria seca total da parte aérea da cultura obtido no momento da colheita de cada uma das parcelas experimentais, e relacionado os valores encontrados para esse fator, com as respectivas lâminas utilizadas. As médias relativas a cada um dos tratamentos empregados não foram submetidas a um teste estatístico, motivo pelo qual esses valores 
não estão contidos na Tabela 13. Assim sendo, foram obtidas as médias de 131,04 gramas, 178,34 gramas, 281,52 gramas e 385,14 gramas, para os tratamentos 1 (testemunha), 2, 3 e 4 respectivamente. Percebe-se por essas médias um acentuado crescimento do peso da matéria seca com o aumento da lâmina de irrigação empregada. Observa-se ainda que, o tratamento 4 , correspondente a maior lâmina $(373,40 \mathrm{~mm})$, foi o que apresentou o maior incremento percentual em relação a testemunha e igual a 193,90 $\%$, variação esta que pode ser considerada bastante alta. Em seguida, observamos o tratamento 3 , também com uma grande diferença percentual em relação à testemunha $\mathrm{e}$ igual a $114,83 \%$. Já o tratamento 2 , representativo de uma lâmina total menor e igual a $206,40 \mathrm{~mm}$, apresentou um incremento percentual menor e igual a $36,09 \%$ quando comparado com o tratamento testemunha. 


\section{CONCLUSÕES}

A proposta desta pesquisa foi submeter a cultura do feijão a diferentes lâminas de água durante o seu desenvolvimento, e assim observar o efeito destas no comportamento espectral da cultura, utilizando para isso a radiometria de campo e posteriores simulações das bandas $\mathrm{TM}_{3}$ e $\mathrm{TM}_{4}$ do satélite Landsat, bem como a influência destas no NDVI, na eficiência do uso da radiação para a produção de grãos e em algumas características agronômicas observadas no decorrer do experimento. De acordo com a análise dos resultados encontrados, o trabalho permite enunciar as seguintes conclusões:

- As diferentes lâminas de água alteraram o comportamento espectral da cultura do feijão nas bandas $\mathrm{TM}_{3}$ e $\mathrm{TM}_{4}$ e nos valores do NDVI, de forma bastante significativa e em diversas fases do crescimento e desenvolvimento dessa cultura.

- A cultura do feijão apresentou comportamento espectral típico de vegetação verde vigorosa em torno de 38 dias do seu ciclo (a contar da data de plantio), permanecendo nessa tipicidade espectral até por volta do $88^{\circ}$ dia do seu ciclo, isto é, por aproximadamente 50 dias.

- A fase do ciclo do feijão em que as correlações entre variáveis agronômicas e variáveis espectrais são maiores, está localizado na parte intermediária do seu ciclo, entre 52 e 62 dias após o plantio, sendo que após esse período as correlações diminuem significativamente. Indica-se esse período como sendo o melhor para monitorar espectralmente a cultura. 
- Ao aumentar o vigor da vegetação da cultura do feijão, aumentaram os valores de reflectância na banda $\mathrm{TM}_{4}$, ocorrendo o inverso com os valores de $\mathrm{TM}_{3}$. Porém, a faixa de valores dentro dos quais ocorreram as reflectâncias na banda $\mathrm{TM}_{4}$ (cerca de 13 a $48 \%$ ), foi muito mais ampla do que para a banda $\mathrm{TM}_{3}$ (cerca de 3 a 10\%).

- O uso do NDVI para avaliar os efeito das várias lâminas de água aplicadas na cultura do feijão, foi mais consistente do que a simples análise das informações obtidas através de bandas individuais e tornou possível, a observância de diferenças nos valores do fator de reflectâcia, tanto na banda $\mathrm{TM}_{3}$, quanto na banda $\mathrm{TM}_{4}$, as quais ocorreram em datas distintas. Por ser derivado das informações espectrais no vermelho e no infravermelho próximo, constituiu em excelente indicador das condições presentes no dossel vegetativo dessa cultura.

- As diferentes lâminas de água influenciaram significativamente a $5 \%$ de probabilidade, a eficiência do uso da radiação para a produção de grãos $\left(\varepsilon_{\mathrm{G}}\right)$ da cultura do feijão, e foram as maiores lâminas que corresponderam aos maiores valores encontrados. Esse comportamento foi coerente com o observado no parâmetro rendimento de grãos, onde as maiores lâminas corresponderam também aos maiores rendimentos.

- A irrigação possibilitou um aumento de cerca de $372 \%$ na produtividade de grãos, se comparado o tratamento submetido a maior lâmina de água $(373,40 \mathrm{~mm}) \mathrm{em}$ relação à testemunha $(164,40 \mathrm{~mm})$. A medida em que as lâminas foram diminuídas, a produtividade de grãos também diminuiu e de forma significativa. As maiores produtividades variaram de 1650,00 a $2540,00 \mathrm{~kg} / \mathrm{ha}$ e ocorreram ao nível de 280 a 370 $\mathrm{mm}$ de lâmina total aplicada. 
- Em relação aos componentes de produção analisados no experimento, pode-se concluir que os tratamentos de irrigação apresentaram maior efeito significativo sobre os componentes altura da planta e número de vagens por planta a $5 \%$ de probabilidade. Maiores valores destes parâmetros foram observados no tratamento correspondente a maior lâmina de água aplicada $(373,40 \mathrm{~mm})$. A lâmina de água de irrigação propiciou também efeito significativo sobre o número de grãos por vagem a $5 \%$ de probabilidade; o componente de produção denominado comprimento da vagem foi o que apresentou a menor influência da lâmina de irrigação.

- Como recomendação final e baseada nos dados obtidos nesta pesquisa, sugerese que outras cultivares de feijão sejam estudadas e em locais diferentes, a fim de que informações mais precisas acerca do efeito de lâminas de água sobre a eficiência do uso da radiação para produção de grãos nesta cultura sejam obtidas, bem como melhor compreendida a influência destas lâminas na sua produção e demais componentes. 


\section{REFERÊNCIAS BIBLIOGRÁFICAS}

ASRAR, G.; MYNENI, R.B.; KANEMASU, E.T. Estimation of plant-canopy attributes from spectral reflectance measurements. In: ASRAR, G., (Ed.). Theory and applications of Optical Remote Sensing. New York: John Wiley, 1989. cap.7, p.252-296.

ASRAR, G.; FUCHS, M; KANEMASU, E.T; HATFIELD, J.L. Estimating absorved photosynthetic radiation and leaf area index from spectral reflectance in wheat. Agronomy Journal, v.76, n.2, p.300-306, Mar./Abr. 1984.

ASSUNÇÃO, H.F. da. Relações entre a radiação fotossinteticamente ativa e a radiação global em Piracicaba - SP. Piracicaba, 1994. 57p. Dissertação (Mestrado) - Escola Superior de Agricultura "Luiz de Queiroz", Universidade de São Paulo.

AZEVEDO, J.A. Efeito de diferentes lâminas de água e doses de adubação nitrogenada na cultura do feijoeiro (Phaseolus vulgaris L.). Piracicaba, 1984. 85 p. Dissertação (Mestrado) - Escola Superior de Agricultura "Luiz de Queiroz", Universidade de São Paulo.

BARET, F.; GUYOT, G.; MAJOR, D.J. Crop biomass evaluation using radiometric measurements. Photogrametria, v.43, n.5, p.241-256, Jun. 1989. 
BATISTA, G.T.; RUDORFF, B.F.T.; OVIEDO, A.F.P. Resposta espectral da soja e sua relação com parâmetros agronômicos. In: SIMPÓSIO BRASILEIRO DE SENSORIAMENTO REMOTO, 5., Natal, 1988. Anais. Natal, CNPq/INPE, 1988. p.406-413.

BAUER, M.E.; VANDERBILT, V.C.; ROBINSON, B.F. et al. Spectral properties of agricultural crops and soils measured from space, aerial, field and laboratory sensors. In: CONGRESS OF INTERNATIONAL SOCIETY PHOTOGRAMETRY, 16. Hamburg, 1980. Proceedings. Hamburg, 1980. p.56-73.

BLAUTH, R.L. Vantagens da irrigação por aspersão. In: Irrigação básica: técnica de irrigação por aspersão. Barueri: Dantas Aspersores, 1982. 30p.

CAIXETA, T.J. Irrigação do Feijoeiro. Informe Agropecuário, v.4, n.46, p.36-40, Out. 1978.

CARDOSO, M.J.; MELO, F.B.; ANDRADE JÚNIOR, A.S. Densidade de plantas de caupi em regime irrigado. Pesquisa Agropecuária Brasileira, v.32, n.4, p. 399-405, 1997.

CARDOSO, P. C. S.; PONZONI, F. J. Considerações sobre a caracterização espectral de folhas extraídas de cinco diferentes espécies. In: SIMPÓSIO BRASILEIRO DE SENSORIAMENTO REMOTO, 8., Salvador, 1996. Anais. Salvador: CNPq/INPE, 1996. p.42-62.

CHOUDHURY, B.J. Relation ships between vegetation indices, radiation and net photosynthesis evaluated by a sensitivity analysis. Remote Sensing Environment, v.22, n.2, p.209-234, Jul. 1987.

COSTA, B. Água no Feijão. Guia Rural Abril, v.1, n.2, p.61-64, 1987. 
DAUGHTRY, C.S.T; GALLO, K.P.; GOWARD, S.N.; et al. Spectral estimates of absorbed radiation and phytomass production in corn and soybean canopies. Remote Sensing of Environment, v.39, n.2, p.141-152, Feb.1992.

DEERING, D.W. Field measurements of bidirecional reflectance. In: Theory and applications of optical remote sensing. New York: John Wiley, 1980. p.14-61.

DOURADO NETO, D; JONG-VAN-LIER, Q; BOTREL, T.A; LIBARDI, P.L. Curva de retenção de água no solo: algoritmo em quickbasic para estimativa dos parâmetros empíricos do modelo de Genutchen: manual de instruções ao usuário. Piracicaba; ESALQ, 1990. 33 p. + disquete.

EMBRAPA. Manual de métodos de pesquisa em feijão. Goiânia: CNPAF, 1976. 81p.

EPIPHANIO, J.C.N. Dados TM Landsat-5 no estudo das culturas do trigo e feijão. Piracicaba, 1988. 140p. Tese (Doutorado) - Escola Superior de Agricultura "Luiz de Queiroz", Universidade de São Paulo.

EPIPHANIO, J.C.N. Metodologia de aquisição de dados ao nível terrestre. In: Sensoriamento remoto na agricultura: conceitos básicos, metodologia e aplicações. São José dos Campos, INPE, 1989. p.53-73.

FANCELli, A.L. Cultura do Feijão. Piracicaba: FEALQ/ESALQ, 1987. 138 p.

FANCELLI, A.L. Feijão Irrigado. In: FANCELLI, A.L.; DOURADO NETO, D. 3 ed. Piracicaba: ESALQ, Departamento de Agricultura, 1992. 177p.

FARIA, R.T. Estudo da lâmina de irrigação na cultura do trigo utilizando o sistema de aspersão em linha. Piracicaba,1981. 120p. Dissertação (Mestrado) - Escola Superior de Agricultura "Luiz de Queiroz", Universidade de São Paulo. 
FOLEGATTI, M.V. Avaliação do desempenho de um "SCHEDULES" na detecção do estresse hídrico em cultura do feijoeiro (Phaseolus vulgaris,L) irrigada com diferentes lâminas. Piracicaba, 1988. 188p. Tese (Doutorado) - Escola Superior de Agricultura 'Luiz de Queiroz", Universidade de São Paulo.

FORMAGGIO, A.R. Características agronômicas e espectrais para sensoriamento temoto de trigo e de feijão. Piracicaba, 1989. 161p. Tese (Doutorado) - Escola Superior de Agricultura "Luiz de Queiroz", Universidade de São Paulo.

FORMAGGIO, A.R; EPIPHANIO, J.C. Reflectância multiespectral TM/Landsat-5 para o sensoriamento remoto das condições de vigor da cultura de feijão. In: SIMPÓSIO BRASILEIRO DE SENSORIAMENTO REMOTO, 6., Manaus, 1990. Anais. Manaus: CNPq/INPE, 1990a. v.3, p.806-813.

FORMAGGIO, A.R; EPIPHANIO, J.C. Relações entre PVI e diferença normalizada e índice de área foliar, cobertura de solo e densidade de clorofila de trigo e de feijão. In: SIMPÓSIO BRASILEIRO DE SENSORIAMENTO REMOTO, 6., Manaus, 1990. Anais. Manaus: CNPq, 1990b. v.3, p.797-805.

FRIZZONE, J.A. Funções de resposta do feijoeiro (Phaseolus vulgaris L.) ao uso de nitrogênio e lâmina de irrigação. Piracicaba, 1986. 133p. Tese (Doutorado) - Escola Superior de Agricultura "Luiz de Queiroz", Universidade de São Paulo.

GALETI, P.A. Conservação do solo; reflorestamento; clima. Campinas: Instituto Campineiro de Ensino Agrícola, 1982. 286p.

GALLO, K.P.; DAUGHTRY, C.S.T.; BAUER, M.F. Spectral estimation in corn canopies. Agronomy Journal, v.78, n.5, p.752-756, Sept./Oct. 1985. 
GALLO, K.P.; DAUGHTRY, C.S.T.; WIEGAND, C.L. Errors in measuring absorved radiation and computing crop radiation use efficiency. Agronomy Journal, v.85, n.6, p. 1222-1228, 1993.

GARDNER, P.F.; PEARCE, R.B.; MITCHELL, R.L. Phisiology of crop plants. Ames: Iowa State University Press, 1985. 337p.

GARRIDO, M.A.T.; PURCINO, J.R.C.; LIMA, C.A.S. Efeito de diferentes regimes de irrigação sobre o rendimento do feijoeiro na região norte de Minas Gerais. In: EMPRESA DE PESQUISA AGROPECUÁRIA DE MINAS GERAIS. Projeto Feijão: relatório 77/78. Belo Horizonte, 1979. p.28-30.

GATES, D.M. Biophysical ecology. New York: Springer-Verlag, 1980. 611p.

GEPTS, P.; FERNANDÉZ, F. Etapas de desarrollo de la planta de frijol comum (Phaseolus vulgaris L.). Cali: CIAT, 1982. 10p.

GLERIANI, J.M. Influência do solo de fundo e da geometria da radiação na resposta espectral da cultura do feijão. São José dos Campos, 1994. 87p. Dissertação (Mestrado) - Instituto Nacional de Pesquisas Espaciais.

GUYOT, G. Optical properties of vegetation canopies. In: STEVEN, M.D.; CLARK, J.A., (Ed.) Applications of remote sensing in agriculture. London: Butterworths, 1990. cap.2, p.19-43.

HANKS, R.J.; KELLER, J.; RASMUSSEN, V.P.; WILSON, G.D. Line source sprinkler for continuous variable irrigation crop production studies. Soil Science Society of America Journal, v.40, p.426-429, 1976. 
HOSTALÁCIO, S.; VÁLIO, I.F.M. Desenvolvimento de plantas de feijão $c v$. Goiano precoce, em diferentes regimes de irrigação. Pesquisa Agropecuária Brasileira, v. 19, n.2, p.211-218, 1984.

HUETE,A.R; JACKSON, R.D. Soil and atmosphere influences on the spectra of partial canopies. Remote Sensing of Environment, v.25, n.1, p.89-105, June 1988.

JACKSON, R.D.; HUETE, A.R. Interpreting vegetation indices. Preventive Veterinary Medicine, v.11, n.2, p.185-200, 1991.

KAY, M. Surface irrigation: system and practice. Oxford: Cotswold, 1986. 143p.

LEMOS, R.C.; SANTOS, R.D. Manual de descrição e coleta de solo no campo. 2.ed. Campinas: SBCS; SNLCS, 1982.45 p.

LIBARDI, P.L.; SAAD, A.M. Balanco hidrico em cultura de feijão irrigada por pivo central em latossolo roxo. Revista Brasileira de Ciência do Solo, v. 18, n.3, p.529$532,1994$.

LOUREIRO, B.T.; MACHADO, P.B.; DENÍCULI, W.; et al. Efeito de diferentes lâminas de água sobre a produtividade do feijoeiro-comum (Phaseolus vulgaris L.). Revista Ceres, v.37, n.211, p.215-226, 1990.

MACHADO, E.C. Eficiência fotossintética. In: SEMINÁRIO DE BIOTECNOLOGIA AGRíCOLA, Piracicaba, 1985. Anais. Piracicaba:FEALQ, 1985. p.175-200.

MACK, H. J.; BONANNO, A. R. Water stress reduces bush beans and sweet corn yelds. Oregon Vegetable Digest, v.30, n.4, p.1-2, 1981. 
MAGALHÃES, A.A.; MILLAR, A.A. Efeito do déficit de água no período reprodutivo sobre a produção de feijão. Pesquisa Agropecuária Brasileira, v.13, n.2, p.55-60, 1978.

MAIA, L.A.F. Desenvolvimento de um software para auxiliar no dimensionamento e manejo da irrigação localizada. Piracicaba, 1994. 158p. Dissertação (Mestrado) Escola Superior de Agricultura "Luiz de Queiroz", Universidade de São Paulo.

MAURER, A.R; ORMROD, D.P.; SCOTT, N.J. Effect of five soil water regimes on growth and composition of snap beans. Canadian Journal of Plant Science, v.49, n.3, p.271-278, 1969.

MILTON, E.J. Principles of field spectroscopy. International Journal Remote Sensing, v.8, n.12, p.1807-1827, Dec. 1987.

MONTEITH, J.L. Solar radiation and productivity in tropical ecosystems. Journal of Applied Ecology, v.9, n.6, p.747-766, 1972.

MORAES, E.C. Radiometria óptica espectral: Comportamento espectral. cap.2. In: SIMPÓSIO BRASILEIRO DE SENSORIAMENTO REMOTO, 8., Salvador, 1996. Anais. Salvador, 1996. p.1-22.

MOREIRA, J.A.A.; SLLEIRA, P.M. da.; STONE, L.F. Irrigação. In: ARAÚJO, R.S.; RAVA, C.A.; STONE, L.F. et al. Cultura do feijoeiro comum no Brasil. Piracicaba: POTAFOS, 1996. p.465-521.

MOREIRA, M.A. Déficit hídrico na cultura do trigo e o impacto na resposta espectral e em parâmetros agronômicos. Piracicaba,1997. 142p. Tese (Doutorado) - Escola Superior de Agricultura "Luiz de Queiroz", Universidade de São Paulo. 
NOVO, E.M.L.M. Sensoriamento remoto: princípios e aplicações. 2.ed. São Paulo: Edgard Blucher, 1995. 308 p.

OLIVEIRA, O.J.; COELHO FILHO, M.A.; CAMPECHE, L.F.S.M.; et al. Análise comparativa do perfil de distribuição de água em aspersores rotativos de média pressão. (compact disc). In: CONGRESSO BRASILEIRO DE ENGENHARIA AGRÍCOLA, 26, Campina Grande, 1997. Resumos. Campina Grande: CBEA,1997.

OLITTA, A.F.L. Necessidade de água das plantas e controle das irrigações. In: SEMINÁRIO NACIONAL DE ENERGIA PARA IRRIGAÇÃO, Minas Gerais, 1988. Anais. CEMTG, CODI, Ministério da Irrigação, 1988.

PAZ, V.P.S.; FOLEGATTI, M.V; PEREIRA, A.S; et al. Efeito de Diferentes Níveis de Irrigação e do Déficit Hídrico na Produção do Feijoeiro (Phaseolus vulgaris, L.). (compact disc). In: CONGRESSO BRASILEIRO DE ENGENHARIA AGRÍCOLA, 26, Campina Grande, 1997. Resumos. Campina Grande: CBEA, 1997.

PEARSON, R.L; MILLER, R.D. Remote mapping of starting crop biomass for estimation of the productivity of the shortgrass praine. In: INTERNATIONAL SYMPOSIUM ON REMOTE SENSING OF ENVIROMENT, 8., Ann Arbor, 1972. Proceedings. Ann Arbor: MI, ERIM, 1972. v.2, p.1355-1373.

PRINCE, S.D. A model of regional primary production for use with coarse-resolution satelite data. International Journal of Remote Sensing, v.12, n.6, p.1313-1330, June 1991.

PROGRAMA NACIONAL DE IRRIGAÇÃO. Tempo de irrigar: manual do irrigante. São Paulo, 1988. 160p. 
QUEIRÓZ, J.E.; CALHEIROS, C.B.M.; PESSOA, P.C.S.; et al. Estratégias ótimas de irrigação do feijoeiro: Terra como fator limitante da produção. Pesquisa Agropecuária Brasileira, v.31, n. 1, p.55-61, 1996.

RAWSON, H.M.; DUNSTONE, R.L.; LONG, M.J:; BEGG, J.E. Canopy development, light interception and seed production in sunflower as influenced by temperature and radiation. Australian Journal of Plant Physiology, v.11, p.255-265, 1984.

REICHARDT, K. A água em sistemas agrícolas. São Paulo: Ed. Manole, 1990. 188p.

RIPPLE, W.J. Spectral reflectance relationships to leaf water stress. Photogrammetric Engineering and Remote Sensing, v.52, n.10, p.1669-1675, Oct. 1986.

RUDORFF, B.F.T.; MOREIRA, M.A.; OVIEDO, A.F.P.; et al. Efeito do nitrogênio e do déficit hídrico na resposta espectral de cultivares de trigo. São José dos Campos, INPE, 1997. 8p.

SAS INSTITUTE. SAS user's guide: statistics. Cary, 1985. 378p.

SILVA, A.F. Dados digitais do satélite SPOT e de radiometria de campo no estudo da cultura do feijoeiro (Phaseolus vulgaris L.) irrigado. Piracicaba, 1995. 118p. Tese (Doutorado) - Escola Superior de Agricultura "Luiz de Queiroz", Universidade de São Paulo.

SILVA, A.F. ; VETORAZZI, C.A. Dados digitais do satélite SPOT e de radiometria de campo no estudo da cultura do feijoeiro ( Phaseolus vulgaris L.) irrigado. (compact disc). In: CONGRESSO BRASILEIRO DE ENGENHARIA AGRÍCOLA, 26, Campina Grande, 1997. Resumos. Campina Grande: CBEA, 1997. 
SLVA, E.L. Suscetibilidade do feijoeiro (Phaseolus vulgaris L.) cv. Goiano Precoce a inundações temporárias do sistema radicular em diferentes fases do seu ciclo vegetativo. Piracicaba, 1982. 76p. Dissertação (Mestrado) - Escola Superior de Agricultura "Luiz de Queiroz", Universidade de São Paulo.

SILVEIRA, P.M.; STEINMETZ, S.; GUIMARÃES, C.M; et al. Lâminas de água e turnos de rega na cultura do feijoeiro de inverno. Pesquisa Agropecuária Brasileira, v.19, n.2, p.219-223, fev. 1984.

SIMONETTI, D.S. The Development and principles of remote sensing. In: COLWELL, R.N. (Ed.) Manual of remote sensing. Falls Church: American Society of Photogrammetry, 1983. v.1, cap.1, p.01-35.

SQUIRE, G.R.; MARSHALL, B.; TERRY, A.C.; MONTEITH, J.L. Response to temperature in a stand of pearl millet. Journal of Experimental Botany, v.35, n.6, p.599-610, 1984.

STEFFEN, C.A. Spectron SE-590: manual de referência. São José dos Campos: INPE, 1988. 23p.

STEFFEN, C.A. Reflectância. São José dos Campos: INPE, 1995. p. 1-15.

STEFFEN, C.A. Fundamentos de radiometria. In: SIMPÓSIO BRASILEIRO DE SENSORIAMENTO REMOTO, 8., Salvador, 1996. Anais. Salvador: INPE, $1996 \mathrm{a}$. p. 1-17.

STEFFEN, C.A. Técnicas radiométricas com o Spectron SE-590. In: SIMPÓSIO BRASLLIRO DE SENSORIAMENTO REMOTO, 8, Salvador, 1996. Anais. Salvador: INPE, 1996b. p.9-14. 
STEFFEN, C.A.; MORAES, E.C. Introdução à radiometria. In: SIMPÓSIO BRASILEIRO DE SENSORIAMENTO REMOTO, 7., Curitiba, 1993. Anais. Curitiba: INPE/SBC, 1993. p.1-12.

STEVEN, M.D.; BISCOE, P.V.; JAGGARD, K.W. Estimation of sugar beet production from reflection in the red and infrared spectral bands. International Journal of Remote Sensing, v.4, n.2, p.325-334, June 1983.

SWAIN, P.H.; DAVIS, S.M. Remote sensing: the quantitative approach. New York: Mac Graw-Hill, 1978. 395p.

THOMAS, J.R; OERTHER, G.F. Estimating nitrogen content of sweet pepper leaves by reflectance measurement. Agronomy Journal, v.64, n.1, p.11-13, 1972.

TIBAU, A.O. Técnicas modernas de irrigação. 5.ed. São Paulo: Nobel, 1986. 223p.

TURNER, N.C.; BEGG, J.E. Plant-water relation and adaptations to stress. Plant and Soil, v.56, p.97-131, 1981.

VAN GENUCHTEN, M.Th. A closed form equation for predicting the hydraulic conductivity of unsaturated soils. Soil Science Society of American Journal, v.44, p.892-898, 1980.

VETTORAZZI, C. A. Sensoriamento remoto orbital. Piracicaba: ESALQ, Depto. de Engenharia Rural, 1992. 134p. (Série Didática, 2).

WESTGATE, M.E; PETERSON, C. M. Flower and pod developmente in water deficient soybeans (Glycine max, L.Merr.). Journal of Experimental Botany, v.44, n.258, p.109-117, Jan. 1993. 
ANEXOA

DADOS METEOROLÓGICOS 


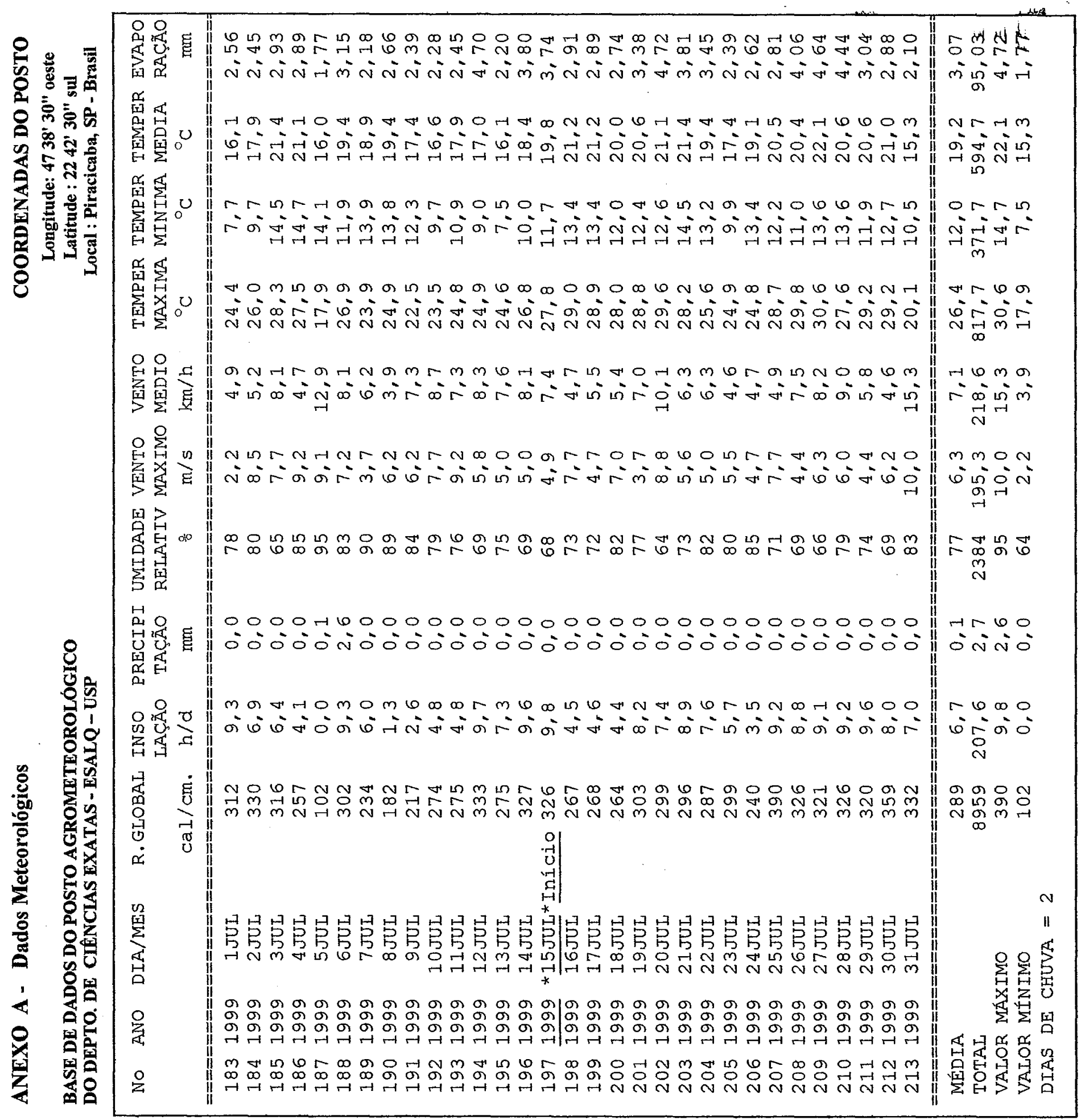




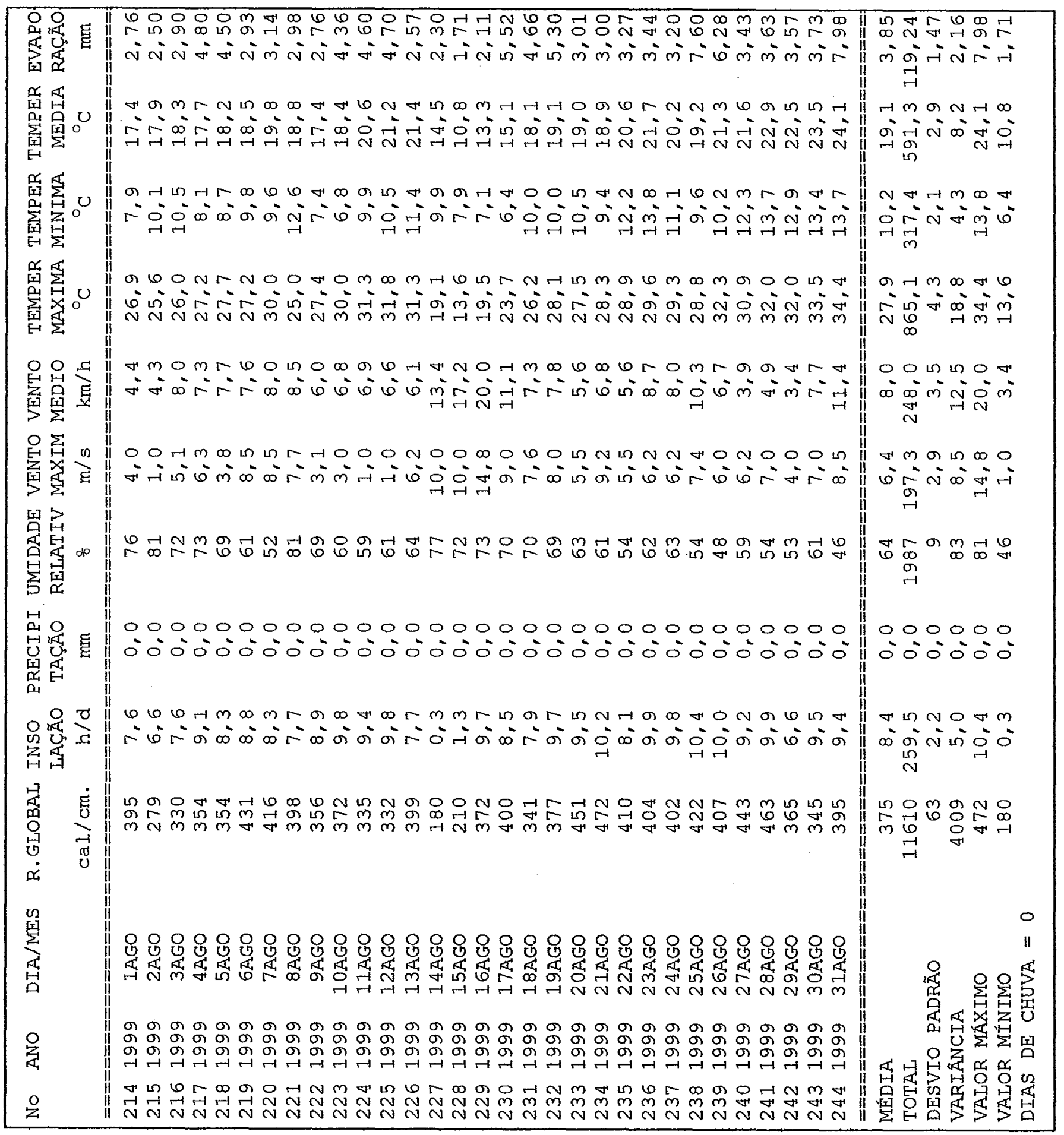




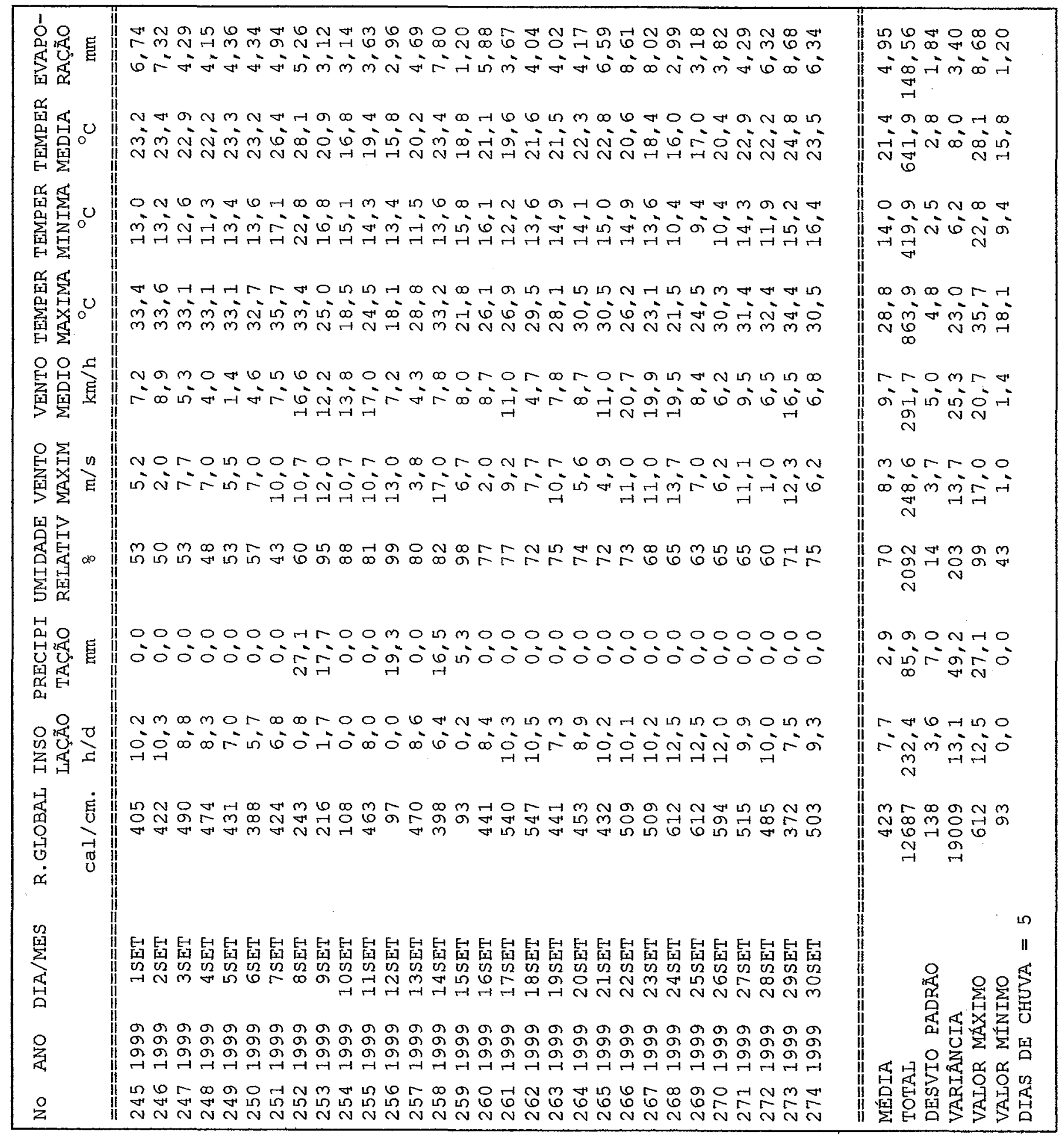




\begin{tabular}{|c|c|c|}
\hline 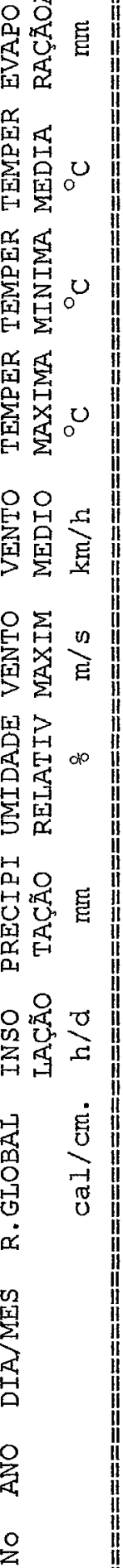 & 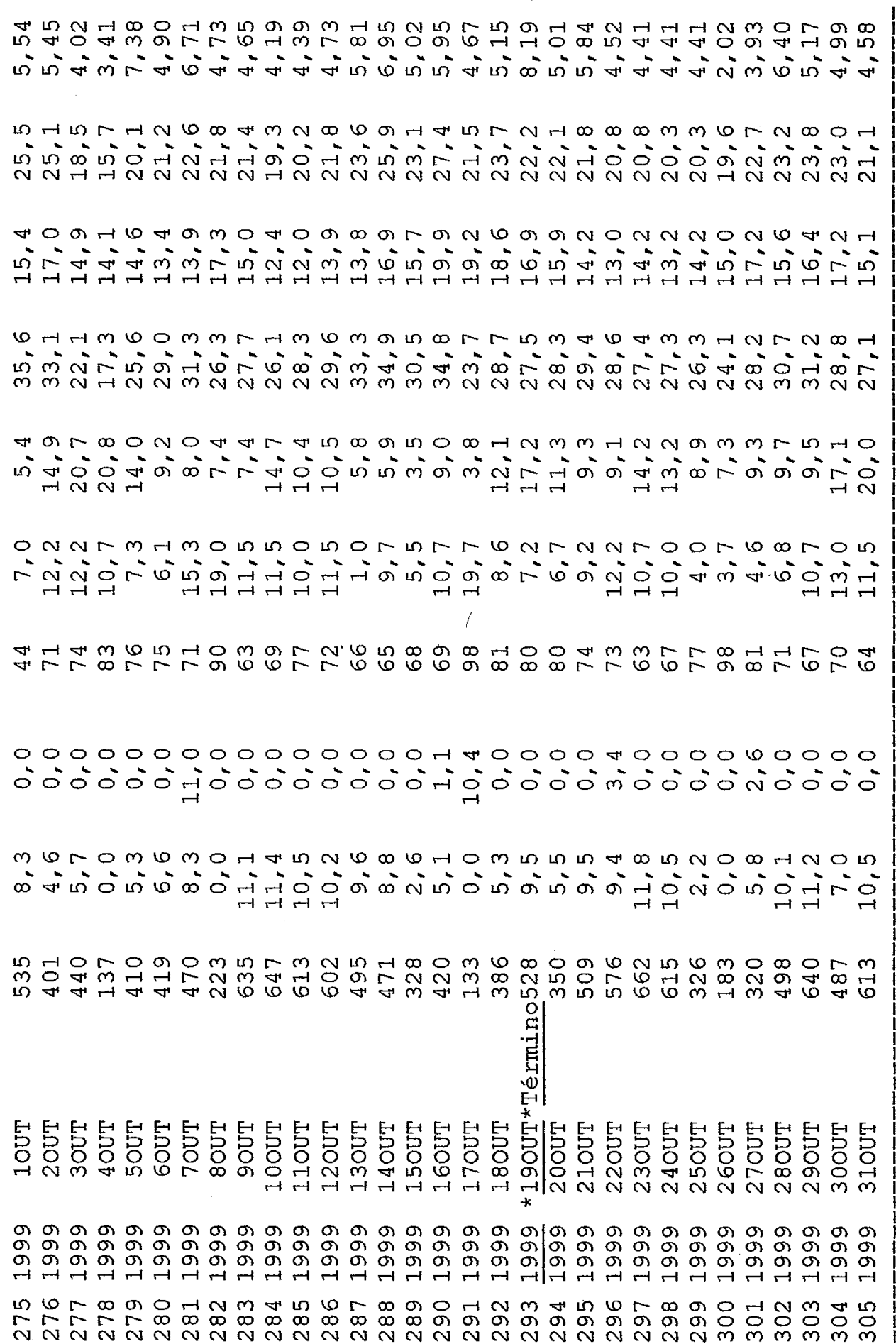 & 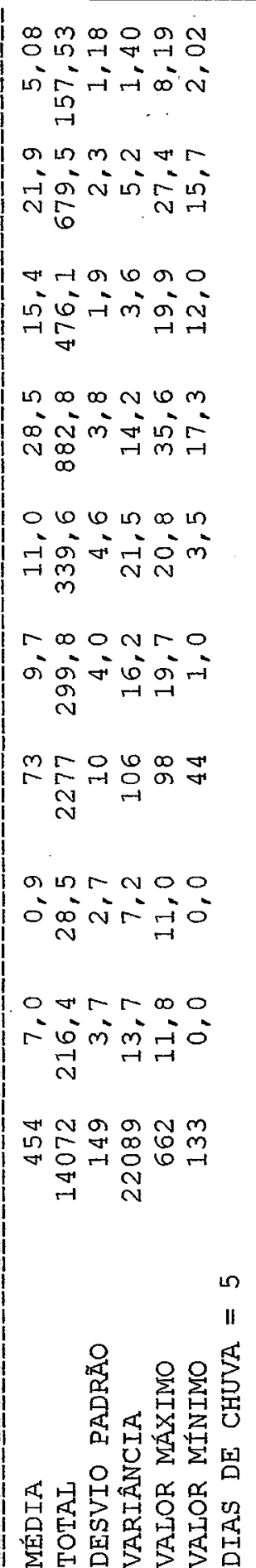 \\
\hline
\end{tabular}


ANEXOB

PROGRAMA COMPUTACIONAL:

EQUAÇÃO DE VAN GENUTCHEN - CALCULO DA UMIIDADE DO SOLO 


\section{ANEXO B - Programa Computacional}

Equação de van Genutchen - Cálculo da Umidade do Solo

Autor: Eng, Agr. Gaflos Augusto Hungria da Cuntia

1) -Cálculo da Tensão da Água no Solo - $\psi(x)$ - Tensiometria

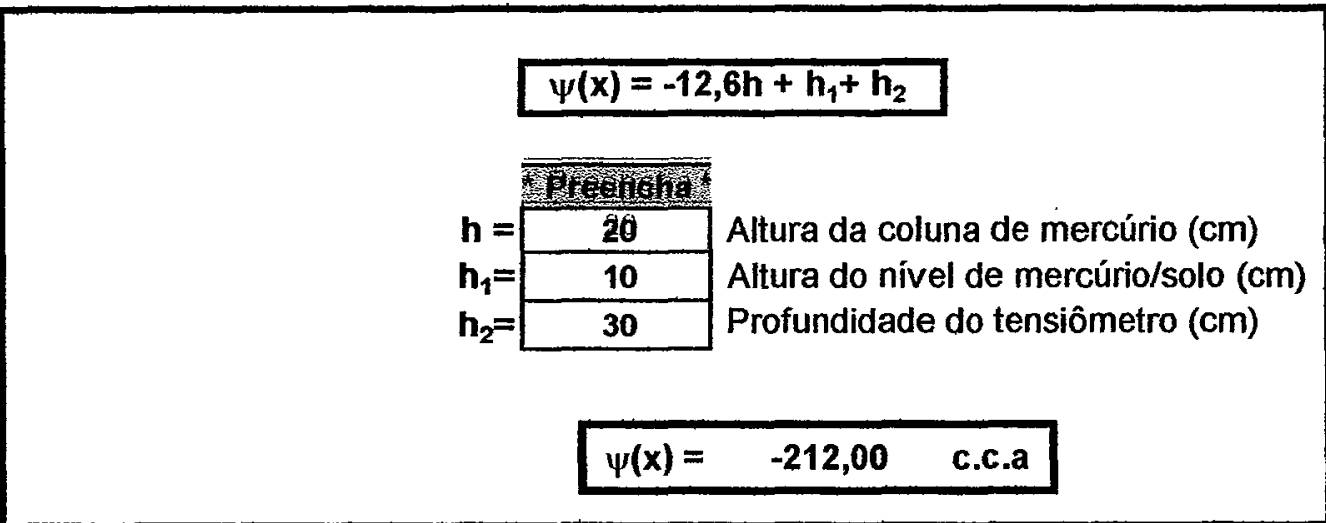

2- Cálculo da Umidade Atual do Solo - Equação de Van Genutchen

$\theta(\psi)=\theta \mathbf{r}+\left[(\theta \mathbf{s}-\theta \mathbf{r}) /\left[1+(\alpha \cdot \psi)^{\mathrm{n}}\right]^{\mathrm{m}}\right]$

\section{DADOS - PREENCHA}

\begin{tabular}{|c|c|}
\hline \multicolumn{2}{|c|}{ 10 } \\
\hline Or: [Umidade Residual $\left.=\left(\mathrm{em}^{3} / \mathrm{cm}^{3}\right)\right]$ & 0,176 \\
\hline Os.. [Umidade de Saturação $\left.-\left(\mathrm{cm}^{3} / \mathrm{cm}^{3}\right)\right]$ & $\overline{0,394}$ \\
\hline$\alpha . .\left[\right.$ Inverso da Tensão $\left.-\left(\mathrm{cm}^{-1}\right)\right]$ & 0,0037 \\
\hline n.. Parâmetro Adimensional & $\mathbf{0 , 7 6 9 0}$ \\
\hline m.. Parâmetro Adimensional & 1,2879 \\
\hline$\Psi$ :s [Tensà da àgua no solo = $(6,6 . \bar{a})]$ & 292,00 \\
\hline
\end{tabular}

$\theta(\psi)=0,276\left(\mathrm{~cm}^{3}\right.$ de águal $\mathrm{cm}^{3}$ de solo $)$ 
3)- Cálculo da Lâmina de Irrigação Necessária

Lâmina Irrigada $=[\theta(100)-\theta(x)] . P / E i$

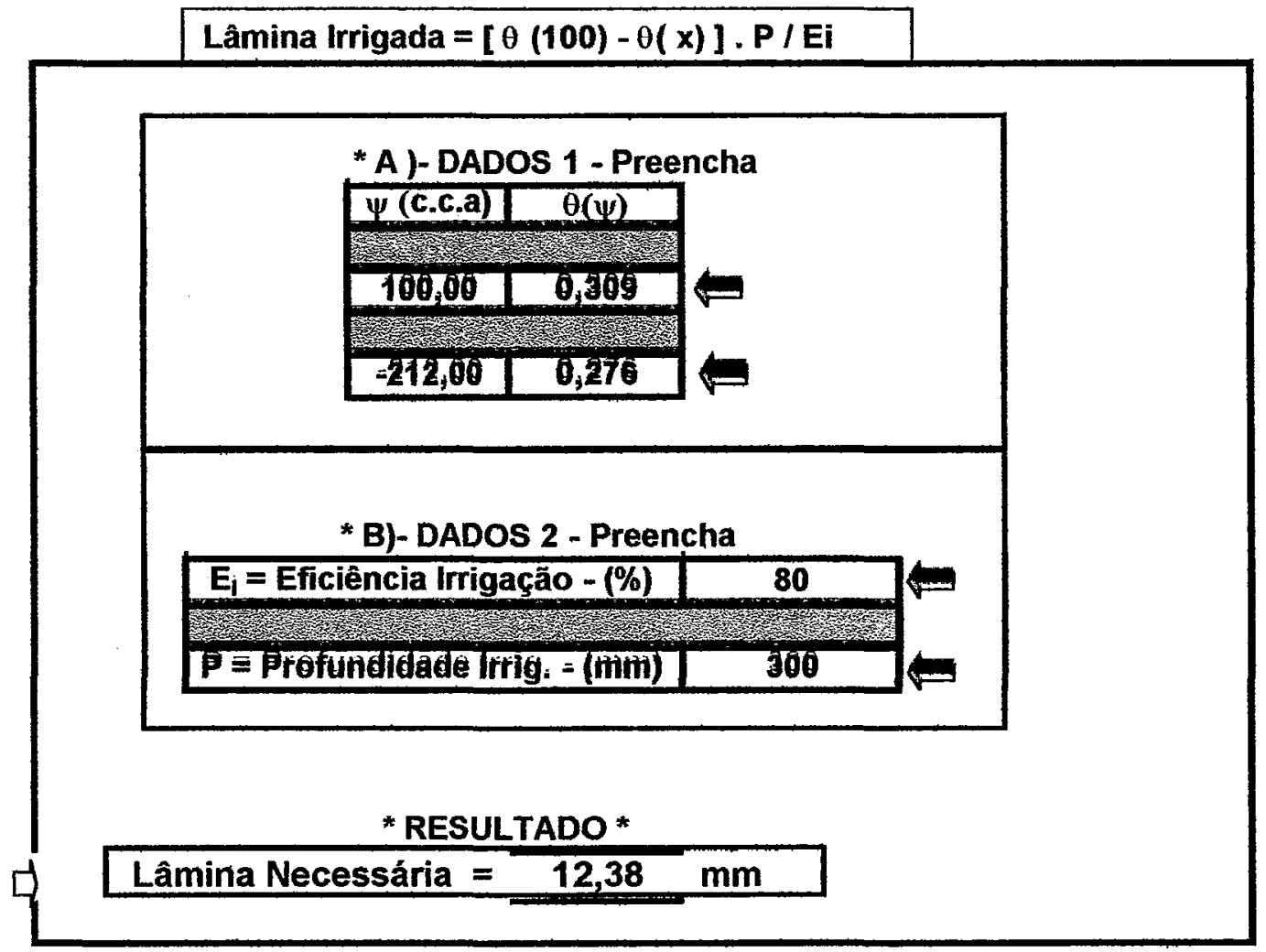




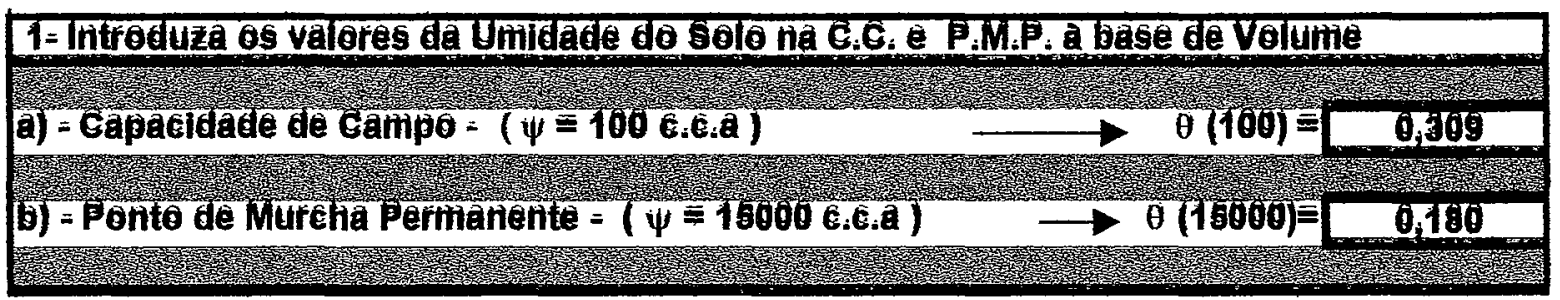

TABELA

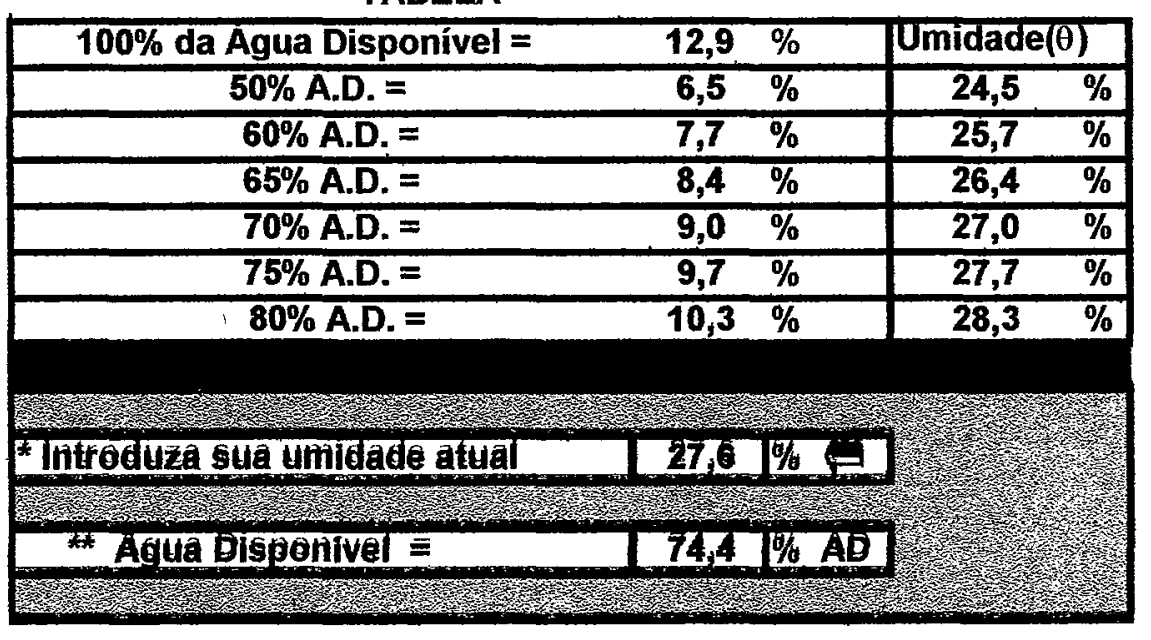

\begin{tabular}{|c|c|}
\hline Tipo de Aspersao: & Aspersio em Linha \\
\hline Profundidade do Tensiômetro & $30,0 \mathrm{~cm}$ \\
\hline Altura da Coluna Mercúrio & $20,0 \mathrm{~cm}$ \\
\hline Ponto de Murcha Permanente & $18,0 \%$ \\
\hline Capacidade de Campo - $(\%)$ & $30,9 \%$ \\
\hline Umidade Atual do Solo - (\%) & $27,6 \%$ \\
\hline Aoua bisponivel $=(\%)$ & $74,4 \%$ \\
\hline 34 & (5) \\
\hline * Intraduza a Lámina Necessấlia (min) & $12.3 n \mathrm{~mm}$ \\
\hline${ }^{\star}$ Introduza a Lâmina Coletada $(\mathrm{mm} / \mathrm{h})$ & 27.01) $\mathrm{mm} / \mathrm{h}=$ \\
\hline Tempo Funcionamento Aspersor & 34 minutos \\
\hline
\end{tabular}




\section{ANEXO C}

DADOS DO FATOR DE REFLECTÂNCIA CORRESPONDENTES AS BANDAS $\mathrm{TM}_{3}$ e TM 4 e RESPECTIVOS VALORES DO ÍNDICE DE VEGETAÇÃO DIFERENÇA NORMALIZADA (NDVI), OBTIDOS ATRAVÉS DE RADIOMETRIA DE CAMPO PARA AS 24 PARCELAS ANALISADAS. 
ANEXO C - Dados do fator de reflectância correspondentes as bandas $\mathrm{TM}_{3} \mathrm{e}$ $\mathrm{TM}_{4}$ e respectivos valores do índice de vegetação diferença normalizada (NDVI), obtidos través da radiometria de campo para as 24 parcelas analisadas e em função da data juliana de aquisição dos dados.

\begin{tabular}{cccccc}
\hline \multicolumn{7}{r}{ Parcela } & Tratamento & Dia Juliano & $\mathrm{TM}_{3}$ & $\mathrm{TM}_{4}$ & NDVI \\
\hline 1 & 1 & 200 & 0.090 & 0.133 & 0.15 \\
1 & 1 & 217 & 0.090 & 0.133 & 0.19283 \\
1 & 1 & 225 & 0.070 & 0.136 & 0.32039 \\
1 & 1 & 238 & 0.047 & 0.178 & 0.58222 \\
1 & 1 & 246 & 0.046 & 0.212 & 0.64341 \\
1 & 1 & 256 & 0.042 & 0.335 & 0.77719 \\
1 & 1 & 264 & 0.044 & 0.326 & 0.76216 \\
1 & 1 & 271 & 0.053 & 0.212 & 0.60000 \\
1 & 1 & 278 & 0.071 & 0.162 & 0.39056 \\
1 & 1 & 285 & 0.102 & 0.134 & 0.13559 \\
1 & 1 & 200 & 0.092 & 0.132 & 0.15 \\
2 & 1 & 217 & 0.092 & 0.132 & 0.17857 \\
2 & 1 & 225 & 0.074 & 0.133 & 0.28502 \\
2 & 1 & 238 & 0.046 & 0.176 & 0.58559 \\
2 & 1 & 246 & 0.040 & 0.210 & 0.68000 \\
2 & 1 & 256 & 0.040 & 0.336 & 0.78723 \\
2 & 1 & 264 & 0.043 & 0.323 & 0.76503 \\
2 & 1 & 271 & 0.051 & 0.211 & 0.61069 \\
2 & 1 & 278 & 0.071 & 0.161 & 0.38793 \\
2 & 1 & 285 & 0.100 & 0.129 & 0.12664 \\
3 & 1 & 200 & 0.092 & 0.132 & 0.15 \\
3 & 1 & 217 & 0.091 & 0.128 & 0.16895 \\
3 & 1 & 225 & 0.066 & 0.133 & 0.33668 \\
3 & 1 & 238 & 0.051 & 0.174 & 0.54667 \\
3 & 1 & 246 & 0.043 & 0.214 & 0.66537 \\
3 & 1 & 256 & 0.044 & 0.334 & 0.76720 \\
3 & 1 & 264 & 0.045 & 0.323 & 0.75543 \\
3 & 1 & 271 & 0.055 & 0.207 & 0.58015 \\
3 & 1 & 278 & 0.077 & 0.163 & 0.35833 \\
3 & 1 & 285 & 0.104 & 0.133 & 0.12236 \\
4 & 2 & 200 & 0.092 & 0.132 & 0.15 \\
4 & 2 & 217 & 0.082 & 0.134 & 0.24074 \\
4 & 2 & 225 & 0.064 & 0.141 & 0.37561 \\
4 & 2 & 238 & 0.042 & 0.190 & 0.63793 \\
4 & 2 & 246 & 0.036 & 0.249 & 0.74737 \\
4 & 2 & 256 & 0.038 & 0.378 & 0.81731 \\
4 & 2 & 264 & 0.040 & 0.368 & 0.80392 \\
4 & 2 & 271 & 0.047 & 0.249 & 0.68243 \\
4 & 2 & 278 & 0.066 & 0.186 & 0.47619 \\
4 & 2 & 285 & 0.095 & 0.142 & 0.19831 \\
5 & 2 & 200 & 0.092 & 0.132 & 0.15 \\
5 & 2 & 217 & 0.080 & 0.132 & 0.24528 \\
\hline
\end{tabular}


ANEXO C - Continuação

\begin{tabular}{|c|c|c|c|c|c|}
\hline Parcela & Tratamento & Dia Juliano & $\mathrm{TM}_{3}$ & $T M_{4}$ & NDVI \\
\hline 5 & 2 & 225 & 0.058 & 0.137 & 0.40513 \\
\hline 5 & 2 & 238 & 0.043 & 0.188 & 0.62771 \\
\hline 5 & 2 & 246 & 0.039 & 0.252 & 0.73196 \\
\hline 5 & 2 & 256 & 0.035 & 0.381 & 0.83173 \\
\hline 5 & 2 & 264 & 0.039 & 0.371 & 0.80976 \\
\hline 5 & 2 & 271 & 0.042 & 0.248 & 0.71034 \\
\hline 5 & 2 & 278 & 0.063 & 0.183 & 0.48780 \\
\hline 5 & 2 & 285 & 0.094 & 0.139 & 0.19313 \\
\hline 6 & 2 & 200 & 0.092 & 0.132 & 0.15 \\
\hline 6 & 2 & 217 & 0.084 & 0.133 & 0.22581 \\
\hline 6 & 2 & 225 & 0.064 & 0.136 & 0.36000 \\
\hline 6 & 2 & 238 & 0.047 & 0.186 & 0.59657 \\
\hline 6 & 2 & 246 & 0.039 & 0.252 & 0.73196 \\
\hline 6 & 2 & 256 & 0.035 & 0.375 & 0.82927 \\
\hline 6 & 2 & 264 & 0.035 & 0.365 & 0.82500 \\
\hline 6 & 2 & 271 & 0.046 & 0.250 & 0.68919 \\
\hline 6 & 2 & 278 & 0.063 & 0.183 & 0.48780 \\
\hline 6 & 2 & 285 & 0.093 & 0.139 & 0.19828 \\
\hline 7 & 3 & 200 & 0.092 & 0.132 & 0.15 \\
\hline 7 & 3 & 217 & 0.078 & 0.144 & 0.29730 \\
\hline 7 & 3 & 225 & 0.061 & 0.148 & 0.41627 \\
\hline 7 & 3 & 238 & 0.039 & 0.226 & 0.70566 \\
\hline 7 & 3 & 246 & 0.036 & 0.286 & 0.77640 \\
\hline 7 & 3 & 256 & 0.033 & 0.421 & 0.85463 \\
\hline 7 & 3 & 264 & 0.037 & 0.416 & 0.83664 \\
\hline 7 & 3 & 271 & 0.045 & 0.281 & 0.72393 \\
\hline 7 & 3 & 278 & 0.063 & 0.211 & 0.54015 \\
\hline 7 & 3 & 285 & 0.090 & 0.148 & 0.24370 \\
\hline 8 & 3 & 200 & 0.092 & 0.132 & 0.15 \\
\hline 8 & 3 & 217 & 0.078 & 0.142 & 0.29091 \\
\hline 8 & 3 & 225 & 0.057 & 0.150 & 0.44928 \\
\hline 8 & 3 & 238 & 0.041 & 0.227 & 0.69403 \\
\hline 8 & 3 & 246 & 0.034 & 0.285 & 0.78683 \\
\hline 8 & 3 & 256 & 0.032 & 0.423 & 0.85934 \\
\hline 8 & 3 & 264 & 0.033 & 0.413 & 0.85202 \\
\hline 8 & 3 & 271 & 0.047 & 0.284 & 0.71601 \\
\hline 8 & 3 & 278 & 0.064 & 0.212 & 0.53623 \\
\hline 8 & 3 & 285 & 0.088 & 0.150 & 0.26050 \\
\hline 9 & 3 & 200 & 0.092 & 0.132 & 0.15 \\
\hline 9 & 3 & 217 & 0.078 & 0.140 & 0.28440 \\
\hline 9 & 3 & 225 & 0.056 & 0.146 & 0.44554 \\
\hline 9 & 3 & 238 & 0.037 & 0.225 & 0.71756 \\
\hline 9 & 3 & 246 & 0.032 & 0.281 & 0.79553 \\
\hline 9 & 3 & 256 & 0.031 & 0.422 & 0.86313 \\
\hline 9 & 3 & 264 & 0.032 & 0.413 & 0.85618 \\
\hline 9 & 3 & 271 & 0.043 & 0.281 & 0.73457 \\
\hline 9 & 3 & 278 & 0.062 & 0.210 & 0.54412 \\
\hline
\end{tabular}


ANEXO C - Continuação

\begin{tabular}{|c|c|c|c|c|c|}
\hline Parcela & Tratamento & Dia Juliano & $\mathrm{TM}_{3}$ & $\mathrm{TM}_{4}$ & NDVI \\
\hline 9 & 3 & 285 & 0.092 & 0.152 & 0.24590 \\
\hline 10 & 4 & 200 & 0.092 & 0.132 & 0.15 \\
\hline 10 & 4 & 217 & 0.078 & 0.139 & 0.28111 \\
\hline 10 & 4 & 225 & 0.056 & 0.155 & 0.46919 \\
\hline 10 & 4 & 238 & 0.039 & 0.255 & 0.73469 \\
\hline 10 & 4 & 246 & 0.030 & 0.315 & 0.82609 \\
\hline 10 & 4 & 256 & 0.028 & 0.462 & 0.88571 \\
\hline 10 & 4 & 264 & 0.032 & 0.454 & 0.86831 \\
\hline 10 & 4 & 271 & 0.044 & 0.316 & 0.75556 \\
\hline 10 & 4 & 278 & 0.059 & 0.226 & 0.58596 \\
\hline 10 & 4 & 285 & 0.086 & 0.160 & 0.30081 \\
\hline 11 & 4 & 200 & 0.092 & 0.132 & 0.15 \\
\hline 11 & 4 & 217 & 0.080 & 0.140 & 0.27273 \\
\hline 11 & 4 & 225 & 0.054 & 0.154 & 0.48077 \\
\hline 11 & 4 & 238 & 0.038 & 0.253 & 0.73883 \\
\hline 11 & 4 & 246 & 0.032 & 0.313 & 0.81449 \\
\hline 11 & 4 & 256 & 0.029 & 0.459 & 0.88115 \\
\hline 11 & 4 & 264 & 0.034 & 0.455 & 0.86094 \\
\hline 11 & 4 & 271 & 0.044 & 0.313 & 0.75350 \\
\hline 11 & 4 & 278 & 0.061 & 0.223 & 0.57042 \\
\hline 11 & 4 & 285 & 0.090 & 0.161 & 0.28287 \\
\hline 12 & 4 & 200 & 0.092 & 0.132 & 0.15 \\
\hline 12 & 4 & 217 & 0.076 & 0.139 & 0.29302 \\
\hline 12 & 4 & 225 & 0.058 & 0.152 & 0.44762 \\
\hline 12 & 4 & 238 & 0.034 & 0.255 & 0.76471 \\
\hline 12 & 4 & 246 & 0.029 & 0.316 & 0.83188 \\
\hline 12 & 4 & 256 & 0.029 & 0.464 & 0.88235 \\
\hline 12 & 4 & 264 & 0.030 & 0.452 & 0.87552 \\
\hline 12 & 4 & 271 & 0.037 & 0.312 & 0.78797 \\
\hline 12 & 4 & 278 & 0.057 & 0.223 & 0.59286 \\
\hline 12 & 4 & 285 & 0.088 & 0.159 & 0.28745 \\
\hline 13 & 4 & 200 & 0.092 & 0.132 & 0.15 \\
\hline 13 & 4 & 217 & 0.076 & 0.144 & 0.30909 \\
\hline 13 & 4 & 225 & 0.056 & 0.155 & 0.46919 \\
\hline 13 & 4 & 238 & 0.034 & 0.260 & 0.76871 \\
\hline 13 & 4 & 246 & 0.031 & 0.319 & 0.82286 \\
\hline 13 & 4 & 256 & 0.030 & 0.465 & 0.87879 \\
\hline 13 & 4 & 264 & 0.030 & 0.462 & 0.87805 \\
\hline 13 & 4 & 271 & 0.040 & 0.316 & 0.77528 \\
\hline 13 & 4 & 278 & 0.056 & 0.229 & 0.60702 \\
\hline 13 & 4 & 285 & 0.086 & 0.162 & 0.30645 \\
\hline 14 & 4 & 200 & 0.092 & 0.132 & 0.15 \\
\hline 14 & 4 & 217 & 0.075 & 0.139 & 0.29907 \\
\hline 14 & 4 & 225 & 0.053 & 0.156 & 0.49282 \\
\hline 14 & 4 & 238 & 0.036 & 0.262 & 0.75839 \\
\hline 14 & 4 & 246 & 0.030 & 0.314 & 0.82558 \\
\hline 14 & 4 & 256 & 0.027 & 0.469 & 0.89113 \\
\hline
\end{tabular}


ANEXO C - Continuação

\begin{tabular}{|c|c|c|c|c|c|}
\hline Parcela & Tratamento & Dia Juliano & $\mathrm{TM}_{3}$ & $\mathrm{TM}_{4}$ & NDVI \\
\hline 14 & 4 & 264 & 0.028 & 0.460 & 0.88525 \\
\hline 14 & 4 & 271 & 0.037 & 0.317 & 0.79096 \\
\hline 14 & 4 & 278 & 0.054 & 0.226 & 0.61429 \\
\hline 14 & 4 & 285 & 0.083 & 0.161 & 0.31967 \\
\hline 15 & 4 & 200 & 0.092 & 0.132 & 0.15 \\
\hline 15 & 4 & 217 & 0.077 & 0.139 & 0.28704 \\
\hline 15 & 4 & 225 & 0.052 & 0.154 & 0.49515 \\
\hline 15 & 4 & 238 & 0.031 & 0.259 & 0.78621 \\
\hline 15 & 4 & 246 & 0.033 & 0.321 & 0.81356 \\
\hline 15 & 4 & 256 & 0.026 & 0.469 & 0.89495 \\
\hline 15 & 4 & 264 & 0.028 & 0.458 & 0.88477 \\
\hline 15 & 4 & 271 & 0.036 & 0.316 & 0.79545 \\
\hline 15 & 4 & 278 & 0.058 & 0.229 & 0.59582 \\
\hline 15 & 4 & 285 & 0.082 & 0.163 & 0.33061 \\
\hline 16 & 3 & 200 & 0.092 & 0.132 & 0.15 \\
\hline 16 & 3 & 217 & 0.085 & 0.147 & 0.26724 \\
\hline 16 & 3 & 225 & 0.062 & 0.150 & 0.41509 \\
\hline 16 & 3 & 238 & 0.039 & 0.228 & 0.70787 \\
\hline 16 & 3 & 246 & 0.035 & 0.287 & 0.78261 \\
\hline 16 & 3 & 256 & 0.034 & 0.429 & 0.85313 \\
\hline 16 & 3 & 264 & 0.036 & 0.419 & 0.84176 \\
\hline 16 & 3 & 271 & 0.051 & 0.285 & 0.69643 \\
\hline 16 & 3 & 278 & 0.066 & 0.215 & 0.53025 \\
\hline 16 & 3 & 285 & 0.092 & 0.154 & 0.25203 \\
\hline 17 & 3 & 200 & 0.092 & 0.132 & 0.15 \\
\hline 17 & 3 & 217 & 0.084 & 0.145 & 0.26638 \\
\hline 17 & 3 & 225 & 0.060 & 0.154 & 0.43925 \\
\hline 17 & 3 & 238 & 0.042 & 0.230 & 0.69118 \\
\hline 17 & 3 & 246 & 0.037 & 0.287 & 0.77160 \\
\hline 17 & 3 & 256 & 0.035 & 0.430 & 0.84946 \\
\hline 17 & 3 & 264 & 0.035 & 0.417 & 0.84513 \\
\hline 17 & 3 & 271 & 0.047 & 0.286 & 0.71772 \\
\hline 17 & 3 & 278 & 0.065 & 0.213 & 0.53237 \\
\hline 17 & 3 & 285 & 0.086 & 0.153 & 0.28033 \\
\hline 18 & 3 & 200 & 0.092 & 0.132 & 0.15 \\
\hline 18 & 3 & 217 & 0.083 & 0.149 & 0.28448 \\
\hline 18 & 3 & 225 & 0.064 & 0.152 & 0.40741 \\
\hline 18 & 3 & 238 & 0.042 & 0.226 & 0.68657 \\
\hline 18 & 3 & 246 & 0.033 & 0.284 & 0.79180 \\
\hline 18 & 3 & 256 & 0.033 & 0.425 & 0.85590 \\
\hline 18 & 3 & 264 & 0.037 & 0.418 & 0.83736 \\
\hline 18 & 3 & 271 & 0.046 & 0.281 & 0.71865 \\
\hline 18 & 3 & 278 & 0.067 & 0.214 & 0.52313 \\
\hline 18 & 3 & 285 & 0.086 & 0.155 & 0.28631 \\
\hline 19 & 2 & 200 & 0.092 & 0.132 & 0.15 \\
\hline 19 & 2 & 217 & 0.090 & 0.135 & 0.20000 \\
\hline 19 & 2 & 225 & 0.067 & 0.143 & 0.36190 \\
\hline
\end{tabular}


ANEXO C - Continuação

\begin{tabular}{|c|c|c|c|c|c|}
\hline Parcela & Tratamento & Dia Juliano & $\mathrm{TM}_{3}$ & $\mathrm{TM}_{4}$ & NDVI \\
\hline 19 & 2 & 238 & 0.044 & 0.194 & 0.63025 \\
\hline 19 & 2 & 246 & 0.043 & 0.256 & 0.71237 \\
\hline 19 & 2 & 256 & 0.037 & 0.384 & 0.82423 \\
\hline 19 & 2 & 264 & 0.038 & 0.371 & 0.81418 \\
\hline 19 & 2 & 271 & 0.054 & 0.251 & 0.64590 \\
\hline 19 & 2 & 278 & 0.068 & 0.187 & 0.46667 \\
\hline 19 & 2 & 285 & 0.097 & 0.145 & 0.19835 \\
\hline 20 & 2 & 200 & 0.092 & 0.132 & 0.15 \\
\hline 20 & 2 & 217 & 0.086 & 0.138 & 0.23214 \\
\hline 20 & 2 & 225 & 0.068 & 0.141 & 0.34928 \\
\hline 20 & 2 & 238 & 0.046 & 0.193 & 0.61506 \\
\hline 20 & 2 & 246 & 0.041 & 0.253 & 0.72109 \\
\hline 20 & 2 & 256 & 0.036 & 0.383 & 0.82816 \\
\hline 20 & 2 & 264 & 0.041 & 0.371 & 0.80097 \\
\hline 20 & 2 & 271 & 0.052 & 0.253 & 0.65902 \\
\hline 20 & 2 & 278 & 0.070 & 0.188 & 0.45736 \\
\hline 20 & 2 & 285 & 0.095 & 0.146 & 0.21162 \\
\hline 21 & 2 & 200 & 0.092 & 0.132 & 0.15 \\
\hline 21 & 2 & 217 & 0.082 & 0.135 & 0.24424 \\
\hline 21 & 2 & 225 & 0.066 & 0.142 & 0.36538 \\
\hline 21 & 2 & 238 & 0.042 & 0.195 & 0.64557 \\
\hline 21 & 2 & 246 & 0.039 & 0.253 & 0.73288 \\
\hline 21 & 2 & 256 & 0.041 & 0.379 & 0.80476 \\
\hline 21 & 2 & 264 & 0.041 & 0.374 & 0.80241 \\
\hline 21 & 2 & 271 & 0.050 & 0.246 & 0.66216 \\
\hline 21 & 2 & 278 & 0.066 & 0.189 & 0.48235 \\
\hline 21 & 2 & 285 & 0.096 & 0.141 & 0.18987 \\
\hline 22 & 1 & 200 & 0.092 & 0.132 & 0.15 \\
\hline 22 & 1 & 217 & 0.086 & 0.131 & 0.20737 \\
\hline 22 & 1 & 225 & 0.069 & 0.138 & 0.33333 \\
\hline 22 & 1 & 238 & 0.048 & 0.183 & 0.58442 \\
\hline 22 & 1 & 246 & 0.042 & 0.215 & 0.67315 \\
\hline 22 & 1 & 256 & 0.038 & 0.337 & 0.79733 \\
\hline 22 & 1 & 264 & 0.043 & 0.326 & 0.76694 \\
\hline 22 & 1 & 271 & 0.055 & 0.214 & 0.59108 \\
\hline 22 & 1 & 278 & 0.069 & 0.168 & 0.41772 \\
\hline 22 & 1 & 285 & 0.101 & 0.137 & 0.15126 \\
\hline 23 & 1 & 200 & 0.092 & 0.132 & 0.15 \\
\hline 23 & 1 & 217 & 0.088 & 0.135 & 0.21076 \\
\hline 23 & 1 & 225 & 0.064 & 0.139 & 0.36946 \\
\hline 23 & 1 & 238 & 0.045 & 0.181 & 0.60177 \\
\hline 23 & 1 & 246 & 0.038 & 0.215 & 0.69960 \\
\hline 23 & 1 & 256 & 0.037 & 0.336 & 0.80161 \\
\hline 23 & 1 & 264 & 0.042 & 0.324 & 0.77049 \\
\hline 23 & 1 & 271 & 0.049 & 0.213 & 0.62595 \\
\hline 23 & 1 & 278 & 0.073 & 0.163 & 0.38136 \\
\hline 23 & 1 & 285 & 0.102 & 0.136 & 0.14286 \\
\hline
\end{tabular}


ANEXO C - Continuação

\begin{tabular}{|c|c|c|c|c|c|}
\hline Parcela & Tratamento & Dia Juliano & $\mathrm{TM}_{3}$ & $\mathrm{TM}_{4}$ & NDVI \\
\hline 24 & 1 & 200 & 0.092 & 0.132 & 0.15 \\
\hline 24 & 1 & 217 & 0.087 & 0.130 & 0.19816 \\
\hline 24 & 1 & 225 & 0.065 & 0.137 & 0.35644 \\
\hline 24 & 1 & 238 & 0.045 & 0.188 & 0.61373 \\
\hline 24 & 1 & 246 & 0.040 & 0.218 & 0.68992 \\
\hline 24 & 1 & 256 & 0.042 & 0.341 & 0.78068 \\
\hline 24 & 1 & 264 & 0.038 & 0.328 & 0.79235 \\
\hline 24 & 1 & 271 & 0.049 & 0.215 & 0.62879 \\
\hline 24 & 1 & 278 & 0.071 & 0.167 & 0.40336 \\
\hline 24 & 1 & 285 & 0.097 & 0.135 & 0.16379 \\
\hline
\end{tabular}




\begin{abstract}
ANEXO D
CURVAS DE ESPECTROMETRIA DE CAMPO PARA A CULTURA DO FEIJÃO AOS 42, 50 E 68 DIAS DE IDADE E CONSIDERANDO AS MÉdIAS ENCONTRADAS PARA O TRATAMENTO 4, O QUAL FOI SUBMETIDO A UMA LÂMINA TOTAL DE $373,40 \mathrm{~mm}$ DURANTE TODO O CICLO.
\end{abstract}


ANEXO D - Curvas de espectrometria de campo para a cultura do feijão aos 42, 50 e 68 dias de idade e considerando as médias encontradas para o tratamento 4 , o qual foi submetido a uma lâmina total de $373,40 \mathrm{~mm}$ durante todo o seu ciclo.

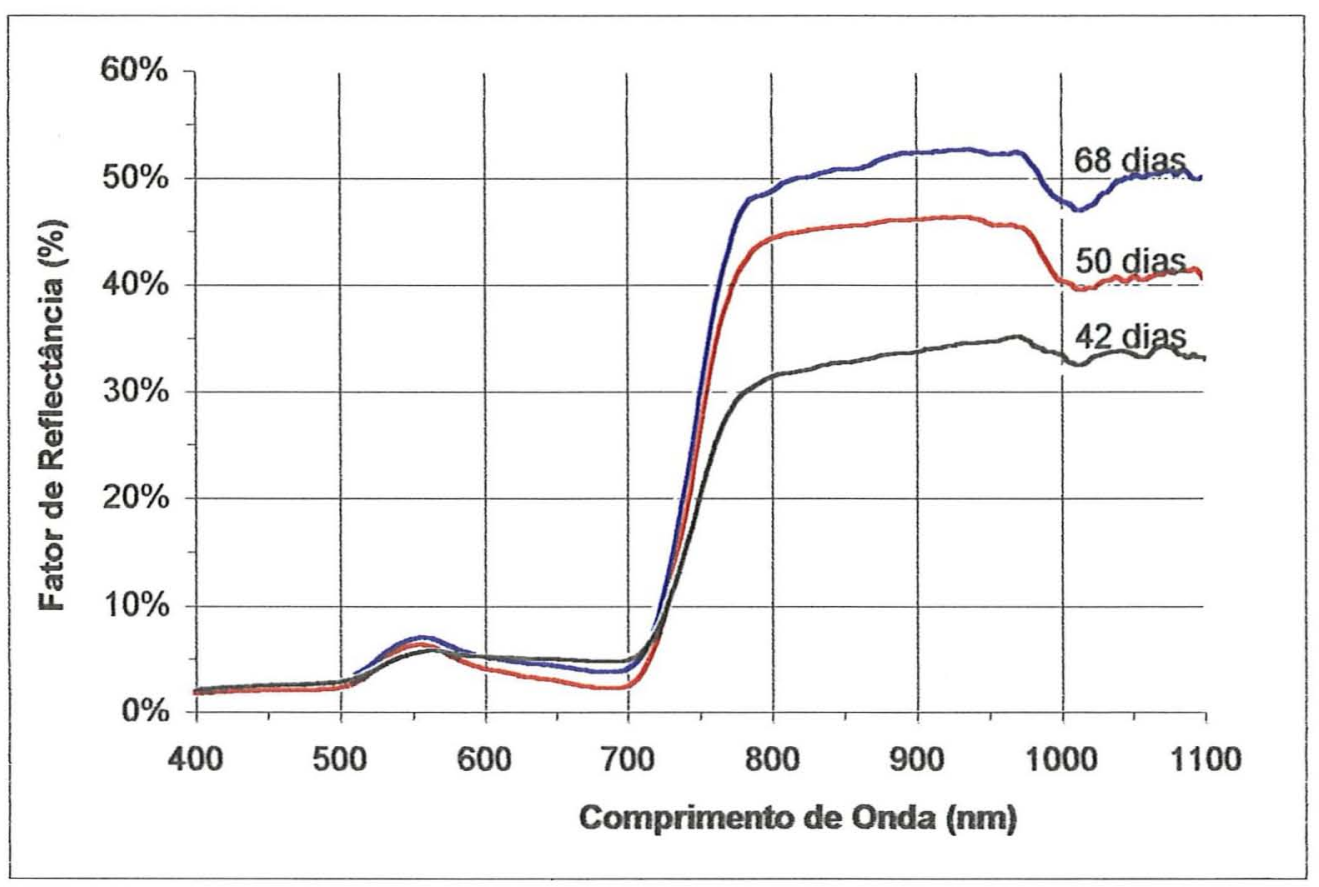




\section{ANEXO E}

MÉdias FinAIS OBTIDAS PARA AS 24 PARCELAS ANALISAdAS E RESPECTIVOS TRATAMENTOS, PARA O NÚMERO DE VAGENS POR PLANTA, NÚMERO DE GRÃOS POR VAGEM, COMPRIMEN'TO DA VAGEM, PROdUTIVIdAde de GRÃos, AltURA MÉdIa da PLANTA, RADIAÇÃo FOTOSSINTETICAMENTE ATIVA ABSORVIDA ACUMULADA E PARA A EFICIÊNCIA DO USO DA RADIAÇÃO PARA PRODUÇÃo DE GRÃos. 
ANEXO E - Médias finais obtidas para as 24 parcelas analisadas e seus respectivos tratamentos, para o número de vagens por planta (N.V.P.), número de grãos por vagem (N.G.V.), comprimento da vagem (T.V.), produtividade de grãos (Grão), altura média da planta (A.P.), radiação fotossintética ativa absorvida acumulada (APARac) e eficiência do uso da radiação para produção de grãos (EFGR).

\begin{tabular}{|ccccccccc|}
\hline PL & T & N.V.P & N.G.V. & T.V. & Grão & A.P. & APAR $_{\text {ac }}$ & EFGR \\
\hline 1 & 1 & 11.8 & 3.8 & 9.40 & 533 & 53.25 & 230.510 & 0.23123 \\
2 & 1 & 13.2 & 3.9 & 9.50 & 540 & 53.22 & 230.640 & 0.23413 \\
3 & 1 & 13.8 & 3.8 & 9.10 & 538 & 52.34 & 222.461 & 0.24184 \\
22 & 1 & 14.4 & 3.6 & 9.80 & 537 & 49.81 & 239.063 & 0.22463 \\
23 & 1 & 12.4 & 3.7 & 8.80 & 543 & 52.12 & 246.908 & 0.21992 \\
24 & 1 & 12.6 & 3.7 & 8.75 & 534 & 53.26 & 247.937 & 0.21538 \\
4 & 2 & 16.4 & 4.0 & 9.40 & 710 & 58.79 & 274.573 & 0.25858 \\
5 & 2 & 15.8 & 3.9 & 9.60 & 722 & 57.76 & 279.407 & 0.25840 \\
6 & 2 & 14.6 & 4.0 & 9.40 & 700 & 57.95 & 270.378 & 0.25890 \\
19 & 2 & 14.8 & 3.8 & 9.05 & 719 & 59.34 & 263.595 & 0.27277 \\
20 & 2 & 14.6 & 3.8 & 9.65 & 711 & 56.88 & 265.268 & 0.26803 \\
21 & 2 & 15.8 & 4.0 & 10.00 & 704 & 59.23 & 271.005 & 0.25977 \\
7 & 3 & 18.8 & 5.0 & 9.80 & 1637 & 65.02 & 306.909 & 0.53338 \\
8 & 3 & 17.8 & 4.9 & 10.40 & 1680 & 63.54 & 310.217 & 0.54156 \\
9 & 3 & 17.6 & 4.9 & 9.25 & 1641 & 62.98 & 314.106 & 0.52244 \\
16 & 3 & 18.4 & 5.1 & 9.95 & 1636 & 64.12 & 302.444 & 0.54093 \\
17 & 3 & 18.0 & 5.1 & 10.60 & 1669 & 64.78 & 305.131 & 0.54698 \\
18 & 3 & 18.6 & 5.0 & 10.20 & 1642 & 65.21 & 305.040 & 0.53829 \\
10 & 4 & 20.6 & 5.3 & 10.20 & 2558 & 72.45 & 329.279 & 0.77685 \\
11 & 4 & 20.8 & 5.2 & 10.50 & 2525 & 73.54 & 325.984 & 0.77458 \\
12 & 4 & 20.6 & 5.2 & 10.60 & 2532 & 75.12 & 334.765 & 0.75635 \\
13 & 4 & 20.8 & 5.3 & 11.00 & 2526 & 76.32 & 338.508 & 0.74622 \\
14 & 4 & 21.0 & 5.2 & 10.90 & 2538 & 72.66 & 342.481 & 0.74106 \\
15 & 4 & 20.8 & 5.3 & 10.80 & 2561 & 82.33 & 343.119 & 0.74639 \\
\hline
\end{tabular}

\section{LEGENDA:}

$P L=$ Parcela

$T=$ Tratamento

N.V.P. = Número de vagens por planta.

N.G.V. = Número de grãos por vagem.

$T . V .=$ Comprimento da vagem $(\mathrm{cm})$.

Grão $=$ Produtividade de grãos $(\mathrm{kg} / \mathrm{ha})$.

A.P. = Altura média da planta $(\mathrm{cm})$.

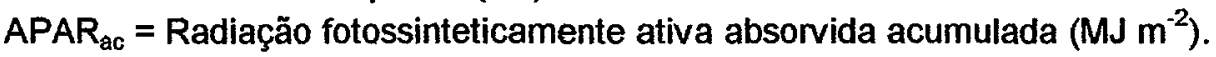

$E F G R=$ Eficiência do uso da radiação para produção de grãos $\left(\mathrm{g} \mathrm{MJ}^{-1}\right)$. 